\title{
29. SILICOFLAGELLATE AND DIATOM STRATIGRAPHY, LEG 16, DEEP SEA DRILLING PROJECT $^{1}$
}

\author{
David Bukry and John H. Foster, U.S. Geological Survey, La Jolla, California
}

\begin{abstract}
The stratigraphic and paleoenvironmental significance of middle Miocene to upper Pleistocene silicoflagellate and diatom assemblages from the Panama Basin area of the eastern tropical Pacific Ocean is presented. The assemblages are dominated by warm-water open-ocean species. Paleotemperatures indicated by silicoflagellates are higher for the Pleistocene than for the Pliocene, and higher temperature correlates with lower productivity. Upwelling is believed to have been a persistent oceanographic feature in the basin, but it was probably reduced when higher surface temperature prevailed, as during the Pleistocene. Seven tropical silicoflagellate biostratigraphic zones are newly described or emended: Dictyocha epiodon Zone, Mesocena elliptica Zone, Distephanus boliviensis Zone, Cannopilus major Zone, Distephanus crux Zone, Distephanus longispinus Zone, and Distephanus octacanthus Zone. Five tropical diatom biostratigraphic zones are newly described or emended; Roperia tesselata Zone, Chaetoceros sp. Zone, Hemidiscus cuneiformis Zone, Coscinodiscus plicatus Zone, Craspedodiscus coscinodiscus Zone. Two new silicoflagellate species, Cannopilus quintus Bukry and Foster and Dictyocha vanandelii Bukry and Foster, and one new replacement name, Distephanus quinquangellus Bukry and Foster, are presented.
\end{abstract}

\section{INTRODUCTION}

Leg 16 of the Deep Sea Drilling Project (DSDP), February-March 1971, from Panama to Hawaii, recovered 210 cores at nine drilling sites. Light-microscope techniques were used to study the fossil silicoflagellates and diatoms of eighty-six samples from these cores.

Skeletal remains of silicoflagellates-microscopic, flagellated, one-celled algae-occur in the Pleistocene to Miocene at DSDP 157 and in the Miocene at DSDP 158. Both sites are located in the Panama Basin, and both were continuously cored. Other Leg 16 sites do not have significant silicoflagellate sequences. Comparison of these fossil assemblages to those in samples from other areas such as the Experimental Mohole in the Pacific Ocean west of Baja California, the Monterey Formation at Newport Bay, California, and the Fairhaven Diatomaceous Earth Member of the Calvert Formation at Fairhaven, Maryland, shows that the Panama Basin assemblages are diverse and well preserved.

Excellently preserved assemblages of microscopic skeletons of diatoms, a class of siliceous unicellular or colonial algae, are abundant at DSDP 157 and DSDP 158. Other Leg 16 sites do not have significant diatom sequences, but a low-diversity mid-Pleistocene assemblage occurs in the highest sample at DSDP 159, and some

'Publication authorized by the Director, U.S. Geological Survey. poorly preserved Oligocene assemblages occur at DSDP 161. The rich diatom deposits extend from the upper Miocene to upper Pleistocene at DSDP 157 and from the middle Miocene to upper Pleistocene at DSDP 158, thus together providing a continuous stratigraphic record for most of the upper Cenozoic.

These silicoflagellate and diatom sequences are compared with those present in the Experimental Mohole (EM) (Figure 1). The continuous coring of the richly fossiliferous Panama Basin sites has allowed silicoflagellate and diatom biostratigraphic zones to be recognized for the upper Cenozoic of the eastern tropical Pacific Ocean. Abundant associated coccoliths permit these zones to be correlated with the previously established, more refined system of coccolith zones (Table 1).

\section{SILICOFLAGELLATES}

\section{Study Methods}

Core samples tabulated for silicoflagellates include a fraction greater than 44 microns separated for diatom study and a fraction less than 44 microns. Core-catcher samples, generally separated by 9 meters, were used almost exclusively. For most core levels, $40 \times 20-\mathrm{mm}$ slide areas of both the coarse and fine fractions were counted at 250 or $100 \times$, and the resultant totals were added together. All identifiable specimens were counted, and a total count of 100 specimens or more was attempted for most core levels. For sparse samples, a maximum of three slides were scanned completely, but even then the count 


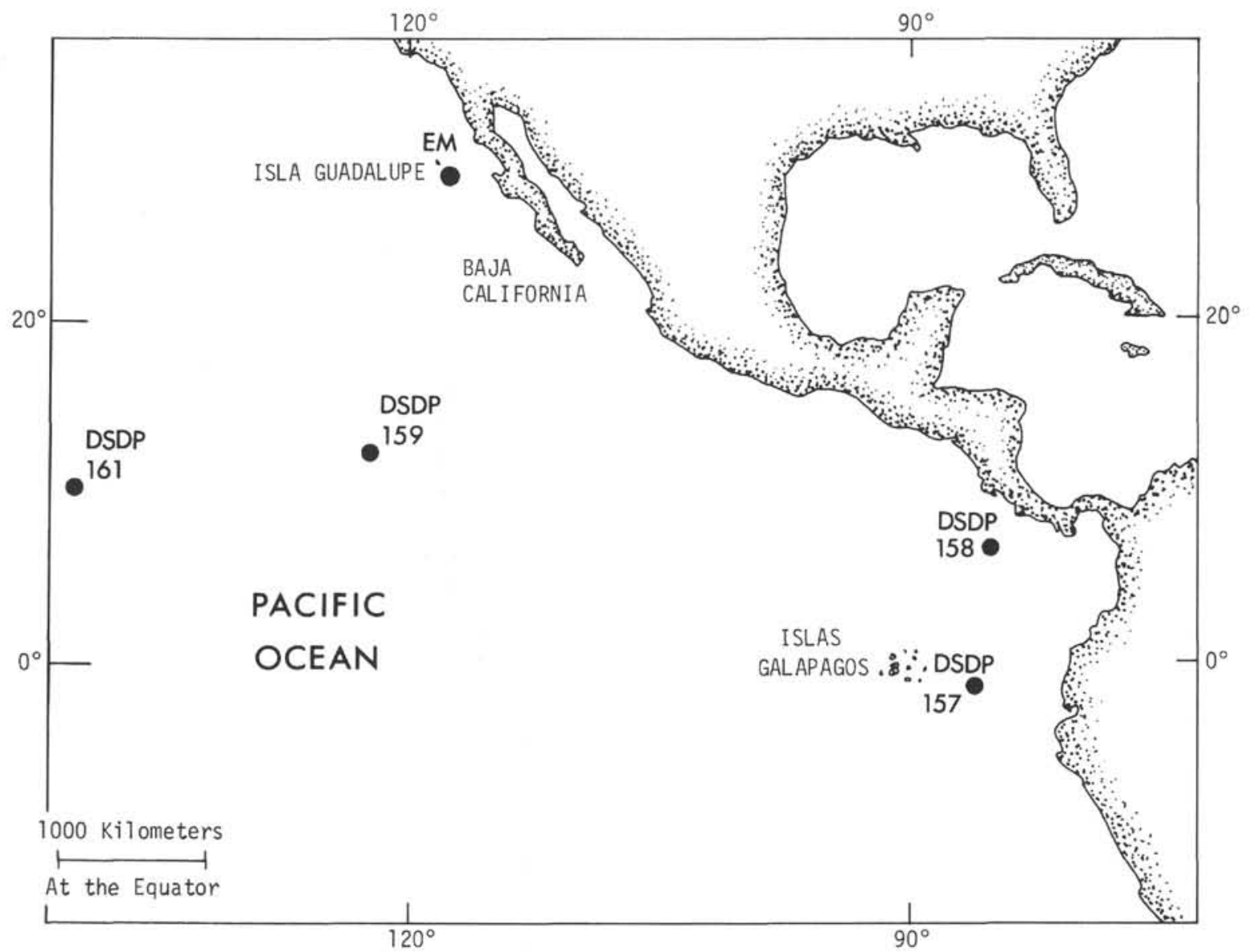

Figure 1. Locations of Deep Sea Drilling Project Leg 16 sites (DSDP) for which silicoflagellate or diatom assemblages are cited and the Experimental Mohole reference section (EM). 
TABLE 1

Approximate Temporal Relation of Tentative Late Cenozoic Phytoplankton Zones in the Eastern Pacific Ocean at Coring Sites DSDP 157, DSDP 158, and the Experimental Mohole (EM)

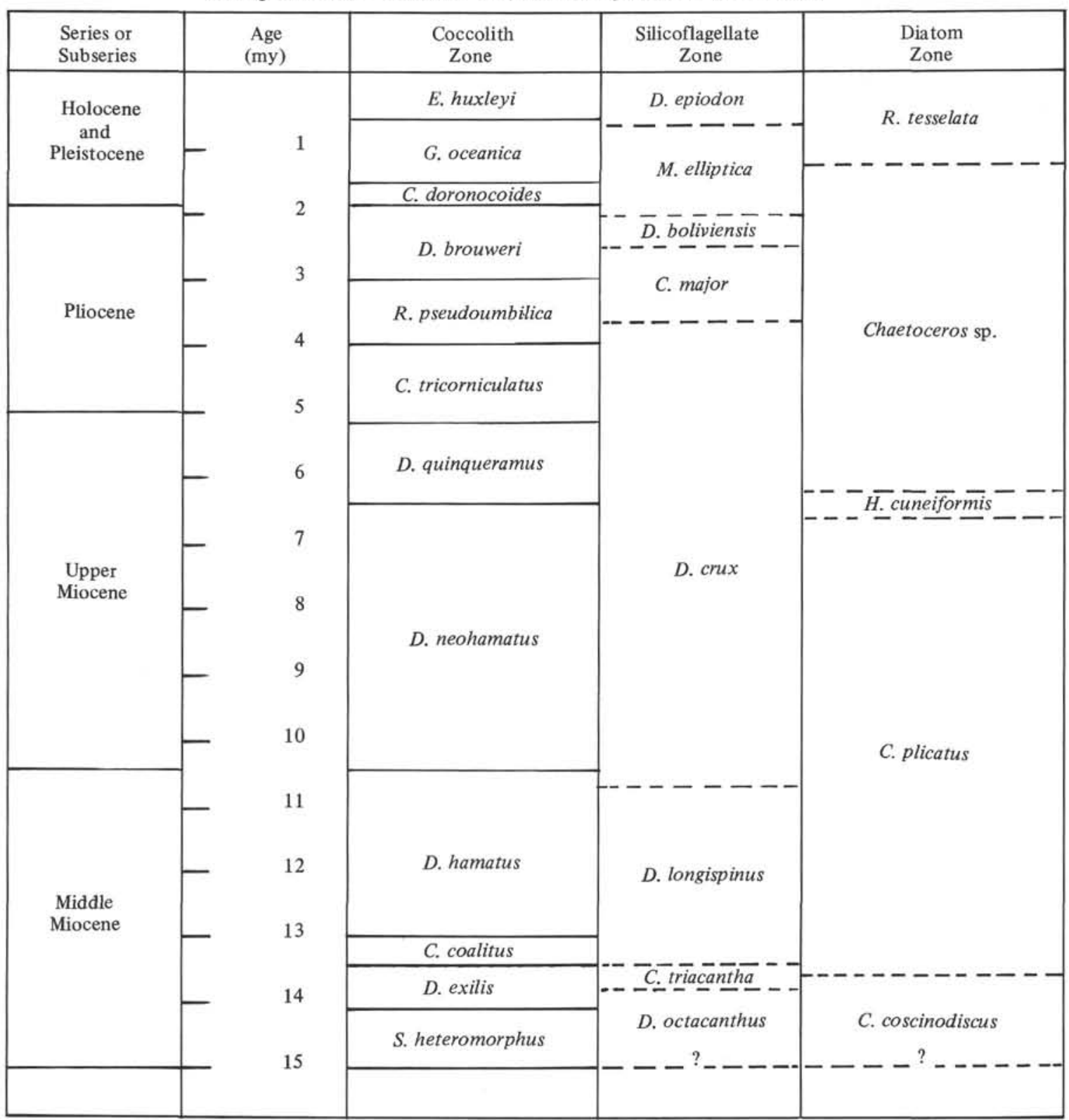

for some samples did not reach 100. To confirm the distributions of stratigraphic marker species-Dictyocha epiodon, Mesocena elliptica, and Octactis pulchra-counts of 300 or more were made for the upper twelve cores of Hole DSDP 157. Percentages for species in the silicoflagellate assemblages and the total counts are presented in Tables 2 to 5 .

\section{Paleoenvironmental Analysis}

Silicoflagellates, like diatoms, are most productive in areas of oceanic upwelling, where the near-surface water has high levels of silica and nutrients (Lipps, 1970). The taxonomic composition of living silicoflagellate populations is controlled to some extent by temperature, which is reflected in a reversal in dominance between the genera
Dictyocha and Distephanus in warm and cold water respectively (Gemeinhardt, 1934). A curve that gives an approximate relation between actual temperature and the ratio of Dictyocha to Distephanus has been prepared by Mandra (1969). This curve has been used as the basis for paleotemperatures determined for DSDP 157 and DSDP 158 in the Panama Basin. For paleotemperature calculations, the Distephanus-like genus Octactis was counted as Distephanus. To allow for very high Dictyocha/Distephanus ratios (warm water) in our assemblages, it was necessary to extrapolate Mandra's curve with 3 by 3 log paper. The curve asymptotically approaches $31^{\circ} \mathrm{C}$, which is in good agreement with the highest annual open-ocean water temperature at low latitude. Temperatures determined for Miocene to Pleistocene cores of the Panama Basin range from 23 to $30^{\circ} \mathrm{C}$, with fluctuations related to 
TABLE 2

Silicoflagellates in DSDP 157A Cores Recorded as Per Cents, with Zones and Geologic Series and Subseries Indicated

\begin{tabular}{|c|c|c|c|c|c|c|c|c|c|c|c|c|c|c|c|}
\hline \multirow[b]{2}{*}{ Sample } & \multicolumn{12}{|c|}{ Taxa } & & \multirow[b]{2}{*}{ Zone } & \multirow[b]{2}{*}{ Series } \\
\hline & 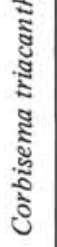 & 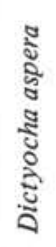 & 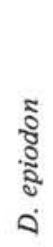 & $\frac{\mathbb{3}}{2}$ & 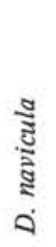 & 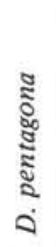 & 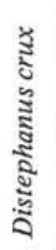 & 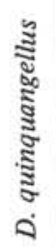 & 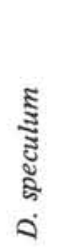 & 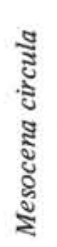 & 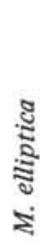 & 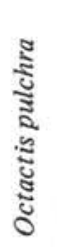 & 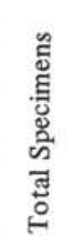 & & \\
\hline $157 \mathrm{~A}-1 \mathrm{~A}-2(8-10 \mathrm{~cm})$ & & 3 & 33 & 60 & & & 1 & & 3 & & 1 & 1 & 105 & \multirow{5}{*}{$\begin{array}{l}\text { Dictyocha } \\
\text { epiodon }\end{array}$} & \multirow{5}{*}{$\begin{array}{l}\text { Holocene } \\
\text { or } \\
\text { Pleistocene }\end{array}$} \\
\hline $157 \mathrm{~A}-1 \mathrm{~A}-4(8-10 \mathrm{~cm})$ & & 4 & 35 & 51 & 1 & & & & 6 & & 5 & & 109 & & \\
\hline $157 \mathrm{~A}-1 \mathrm{~A}(\mathrm{CC})$ & & 2 & 22 & 69 & & 1 & 1 & & 2 & & 4 & & 111 & & \\
\hline $157 \mathrm{~A}-2 \mathrm{~A}(\mathrm{CC})$ & & & 9 & 85 & & & 1 & 1 & 1 & & 1 & 1 & 85 & & \\
\hline $157 \mathrm{~A}-3 \mathrm{~A}(\mathrm{CC})$ & 1 & 1 & 8 & 81 & & & 1 & 1 & 2 & 1 & 1 & 3 & 103 & & \\
\hline
\end{tabular}

variation in the percentage of Dictyocha (Tables 6 and 7).

A second technique using silicoflagellate populations for determining paleotemperatures was presented by Martini (1971). This technique is based on a ratio of Dictyocha fibula to Distephanus speculum. However, a test of that method resulted in an unreasonable temperature range of $0-40^{\circ} \mathrm{C}$, with core to core variations of as much as $20^{\circ} \mathrm{C}$, and it was therefore considered unreliable for the Panama Basin.

Fluctuation in the carbonate percentage of Pacific Ocean sediment has been related to climatic fluctuation (Arrhenius, 1952; Nayudu, 1964; Hays et al., 1969). The hypothesis of these authors is that an increased carbonate percentage corresponds to cooler climatic conditions. Muhina (1971) stated, however, that carbonate peaks correspond to warmer climatic conditions, on the basis of a study of the relation of these peaks to the distribution of cool- and warm-water diatoms in the equatorial Pacific. The variation of carbonate percentage and indicated temperature in our study is found to be mixed (Table 6).

Strata in the Panama Basin that have the most abundant silicoflagellates (presumably reflecting upwelling) correspond generally with low-temperature points on the indicated-temperature curve. Muhina (1971) demonstrated a similar relation for central equatorial Pacific strata. This correspondence could result from optimum production of silicoflagellates at lower temperatures or conversely from optimum preservation during periods of rapid sedimentation.

Because the Mandra (1969) indicated-temperature curve worked well for Panama Basin assemblages, it was applied to assemblages from the Miocene of California and Maryland, which were studied for stratigraphic comparison. An especially abundant population of the two quadrate Distephanus species $D$. crux and D. longispinus dominates the assemblages. The resultant indicated temperatures are very cold-less than $4^{\circ} \mathrm{C}$. These temperatures are considered too low in view of the presence of discoasters at the California section-Monterey Shale at
Newport Beach (Wilcoxon, 1969) - and temperate-water fossils at the Maryland section-Calvert and Choptank Formations (T.G. Gibson, personal communication, 1972). In open-ocean assemblages of Miocene age, these quadrate Distephanus species are generally subordinate at both high and low latitude (Ling, 1970; Martini, 1971), whereas in assemblages from land localities (presumably representing more nearshore conditions), quadrate Distephanus species predominate. This relation suggests that coastal environmental factors, in addition to low temperatures, may contribute to the development of large populations of quadrate Distephanus.

The relation of temperature and environment to skeletal form of living silicoflagellates has been investigated by Van Valkenburg and Norris (1970). A laboratory culture of a low-temperature low-salinity stock of Dictyocha fibula from Puget Sound, Washington, was found to produce a variety of irregular skeletal forms that are similar to living varieties of $D$. fibula illustrated from a somewhat similar environment in the Gulf of Matías, Argentina (see Pl. 10-11 in Loeblich et al., 1968). These irregular forms are missing from our samples from the Panama Basin and from other open-ocean areas (Ling, 1970), suggesting (a) that the irregular forms develop only in coastal waters or (b) that selective dissolution prevents their fossilization. Some of the largest silicoflagellate skeletons from the Panama Basin, Cannopilus spp. and Distephanus boliviensis, occur in late Pliocene sediment at DSDP 157. The indicated temperature for this time is relatively low in contrast to a higher indicated temperature for the early Pleistocene. Generally high temperature is noted for the Panama Basin during the Pleistocene. This Pleistocene temperature maximum is supported by the virtual absence of the cool-water coccolith Coccolithus pelagicus in the Pleistocene and by its common occurrence in the Pliocene (Bukry, this volume).

In summary, the silicoflagellate assemblages from the Panama Basin indicate that generally warm, nutrient-rich, open-ocean water has been characteristic of the area from 
TABLE 3

Silicoflagellates in DSDP 157 Cores Recorded as Per Cent, with Zones and Geologic Series and Subseries Indicated

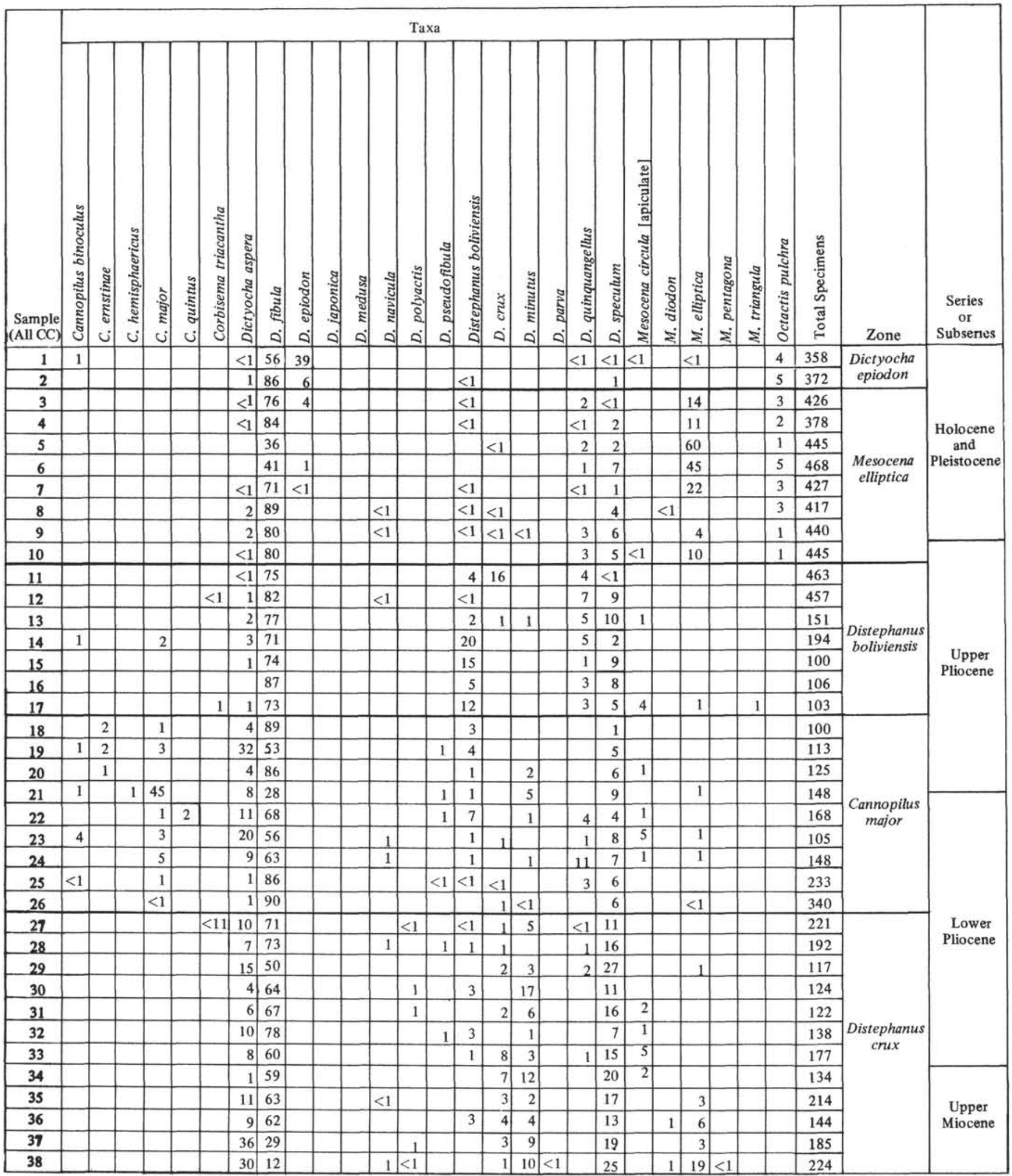


TABLE 4

Silicoflagellates in DSDP 158 Cores Recorded as Per Cents, with Zones and Geologic Series and Subseries Indicated

\begin{tabular}{|c|c|c|c|c|c|c|c|c|c|c|c|c|c|c|c|c|c|c|}
\hline \multirow[b]{2}{*}{$\begin{array}{c}\text { Sample } \\
\text { (All CC) }\end{array}$} & \multicolumn{15}{|c|}{ Taxa } & & \multirow[b]{2}{*}{ Zone } & \multirow[b]{2}{*}{ Subseries } \\
\hline & 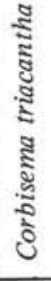 & 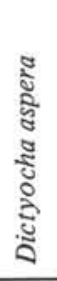 & 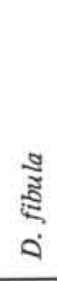 & 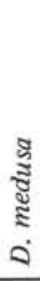 & 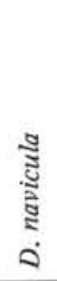 & 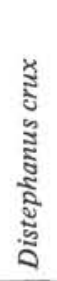 & 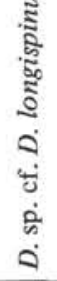 & $\begin{array}{l}\tilde{\Xi} \\
\tilde{\Xi} \\
\tilde{\Xi} \\
\dot{0}\end{array}$ & 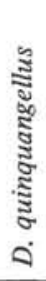 & 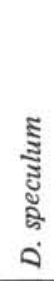 & 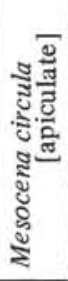 & 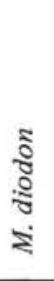 & 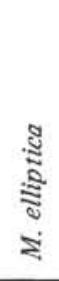 & 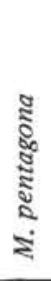 & 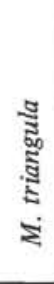 & 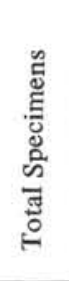 & & \\
\hline 10 & & 75 & 5 & & & 5 & & 5 & & 5 & & & 5 & & & 20 & \multirow{16}{*}{$\begin{array}{c}\text { Distephanus } \\
\text { crux }\end{array}$} & \multirow{14}{*}{$\begin{array}{l}\text { Upper } \\
\text { Miocene }\end{array}$} \\
\hline 11 & & 14 & 29 & & 36 & 1 & & & & 20 & & & & & & 106 & & \\
\hline 12 & & 15 & 77 & & & & & 2 & 1 & 6 & & & & & & 128 & & \\
\hline 13 & & 11 & 77 & & & 8 & & 4 & & & & & & & & 100 & & \\
\hline 14 & & 23 & 62 & & & 3 & & 3 & & 8 & & & & & 3 & 39 & & \\
\hline 15 & & 23 & 69 & & & & & & & 7 & & & 1 & & & 109 & & \\
\hline 16 & & 20 & 60 & & $<1$ & & & 13 & 2 & 8 & & & & & & 274 & & \\
\hline 17 & & 65 & 4 & & & & & & & 24 & & & 7 & & & 100 & & \\
\hline 18 & & 24 & 65 & & & 2 & & 6 & & 3 & & & & & & 100 & & \\
\hline 19 & & 14 & 81 & 5 & & 1 & & & & & & & & & & 109 & & \\
\hline 20 & & 84 & 3 & 1 & & 1 & 1 & & & 9 & 2 & 1 & & & & 163 & & \\
\hline 21 & & 72 & & 5 & & & & 10 & & 10 & 5 & & & & & 21 & & \\
\hline 22 & & 71 & 3 & 1 & & 7 & & 1 & 1 & 15 & 3 & & & & & 120 & & \\
\hline 23 & & 60 & 3 & & & 1 & & 2 & 2 & 32 & & & 1 & & & 126 & & \\
\hline 24 & & 73 & 2 & 1 & & 15 & & 2 & & 5 & 2 & 1 & & & & 130 & & \multirow{10}{*}{$\begin{array}{l}\text { Middle } \\
\text { Miocene }\end{array}$} \\
\hline 25 & & 86 & 6 & & & & & & & 8 & & & & & & 49 & & \\
\hline 26 & & 62 & 2 & & & 13 & 15 & 1 & & 5 & 5 & & & & & 131 & \multirow{7}{*}{$\begin{array}{c}\text { Distephanus } \\
\text { longispinus }\end{array}$} & \\
\hline 27 & & 69 & 1 & 3 & & 1 & 1 & 6 & & 10 & 3 & 3 & 2 & & 1 & 144 & & \\
\hline 28 & & 66 & & & & 1 & 3 & 1 & & 8 & 2 & 8 & 12 & & 1 & 107 & & \\
\hline 29 & & 88 & 5 & & & & & & & 4 & 2 & & & & 1 & 101 & & \\
\hline 30 & & 56 & 2 & 1 & & 5 & & 6 & & 22 & & 5 & 1 & 1 & & 110 & & \\
\hline 31 & & 94 & 1 & & & 3 & & & & 2 & & & & & & 102 & & \\
\hline 32 & & 66 & 4 & 1 & & 20 & 1 & 1 & & 7 & & & & & & 109 & & \\
\hline 33 & 3 & 74 & 5 & 2 & & 3 & 6 & 2 & & 4 & & & 1 & & & 117 & $\begin{array}{l}\text { Corbisema } \\
\text { triacantha }\end{array}$ & \\
\hline
\end{tabular}

middle Miocene to Holocene. The typically small numbers of quadrate Distephanus specimens, especially in middle Miocene assemblages, contrast with an abundance of these forms at cooler nearshore mid-latitude localities and also suggest a warm open-ocean paleoenvironment for the Panama Basin. This study indicates that, because of reduced upwelling, surface water of the eastern tropical Pacific was especially warm during the time of Pleistocene glaciation. Whether the reduced upwelling was a cause or an effect of the glaciation, or whether both had a common cause, present-day periods of Pacific warming are associated onshore in the northern mid-latitudes with cold winters (Namias, 1969).

\section{Tropical Silicoflagellate Zonation}

Only with the advent of the Deep Sea Drilling Project has it been possible to determine the stratigraphic relations of silicoflagellate species at a single site for an extensive part of the geologic record (Martini, 1971). Previous stratigraphic studies have been based on discontinuous outcrops ashore and on short cores from ocean areas (Mandra, 1968; Hays et al., 1969; Ling, 1970, 1971; Jousé, 1971). The continuously cored Miocene through Pleistocene sediments at DSDP 157 and DSDP 158 in the Panama Basin provide an excellent record of fossil silicoflagellate assemblages in the eastern tropical Pacific that can be related to the stratigraphic systems of associated fossil groups-diatoms, radiolarians, foraminifers, and coccoliths.

As with diatoms, silicoflagellate stratigraphy of warmwater areas may not be comparable with that of coolwater areas owing to the ecologic limitations of various taxa. For example, the short-spined, compact silicoflagellates Dictyocha subarticos Ling, Distephanus crux cf. "var." stauracanthus (Ehrenberg), and Distephanus octangulatus Wailes of North Pacific cores (Ling, 1970) do not occur in samples from the Panama Basin. Species of Cannopilus occur only in the Miocene of North Pacific cores, 
TABLE 5

Silicoflagellates in Experimental Mohole Cores Recorded as Per Cents,

with Zones and Geologic Series and Subseries Indicated

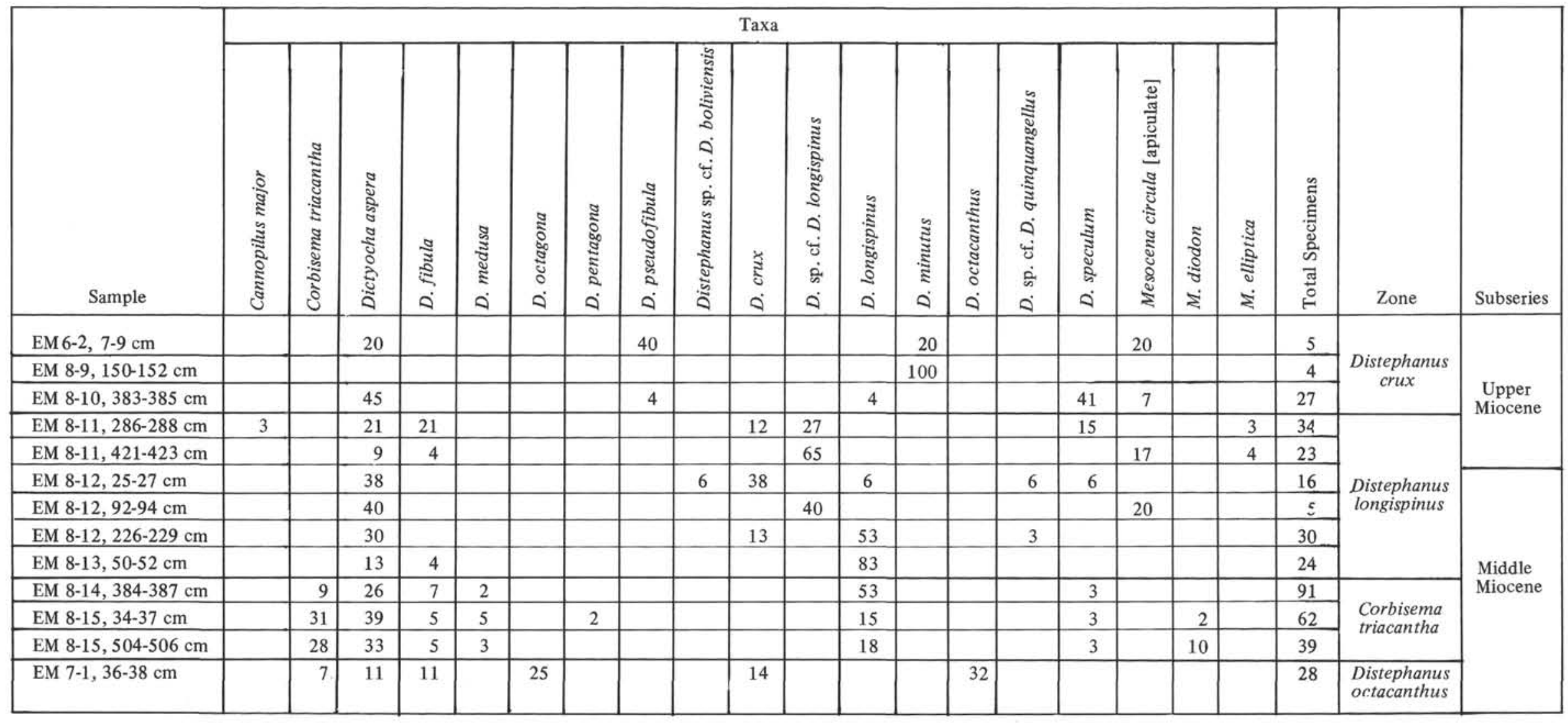


TABLE 6 Compared with Carbonate Percentage of Sediment and Indicated Temperature.

\begin{tabular}{|c|c|}
\hline $\begin{array}{c}\text { Series } \\
\text { or } \\
\text { Subseries }\end{array}$ & Zone \\
\hline & ${ }^{\text {Dictyocha }}{ }_{\text {epiodon }}$ \\
\hline $\begin{array}{l}\text { and } \\
\text { Pleistocene }\end{array}$ & $\begin{array}{c}\text { Mesocena } \\
\text { elliptica }\end{array}$ \\
\hline \multirow{2}{*}{$\begin{array}{c}\text { Upper } \\
\text { Pliocene }\end{array}$} & $\begin{array}{c}\text { Distephanus } \\
\text { boliviensis }\end{array}$ \\
\hline & $\begin{array}{l}\text { Cannopilus } \\
\text { major }\end{array}$ \\
\hline $\begin{array}{l}\text { Lower } \\
\text { Pliocene }\end{array}$ & \multirow[b]{2}{*}{$\begin{array}{l}\text { Distephanus } \\
\text { crux }\end{array}$} \\
\hline $\begin{array}{c}\text { Upper } \\
\text { Miocene }\end{array}$ & \\
\hline \multirow[t]{2}{*}{$\begin{array}{c}\text { Middle } \\
\text { Miocene }\end{array}$} & $\begin{array}{l}\text { Distephanus } \\
\text { longispinus }\end{array}$ \\
\hline & $\begin{array}{l}\text { Corbisema } \\
\text { triacantha }\end{array}$ \\
\hline
\end{tabular}

Generic Abundance
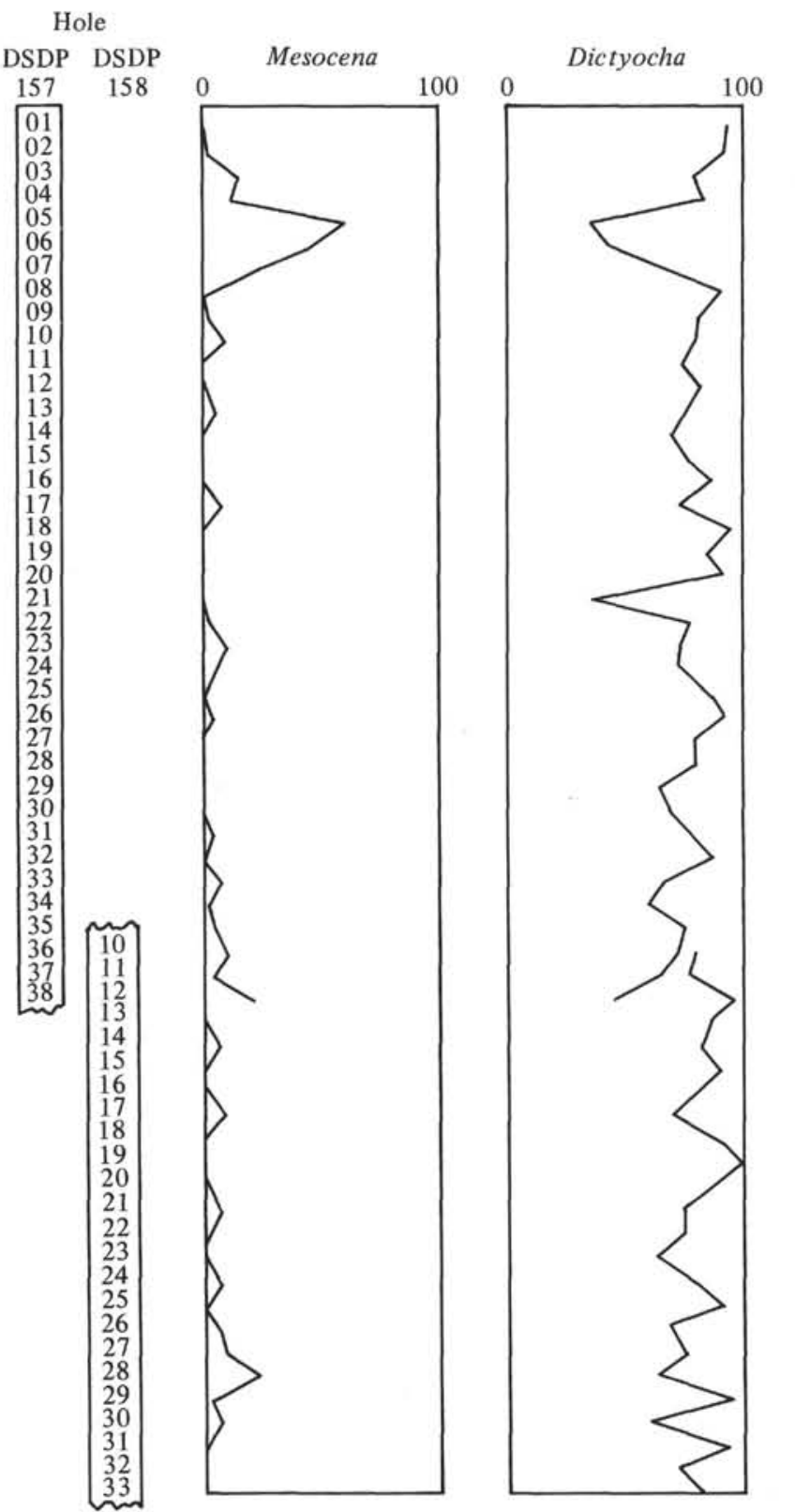

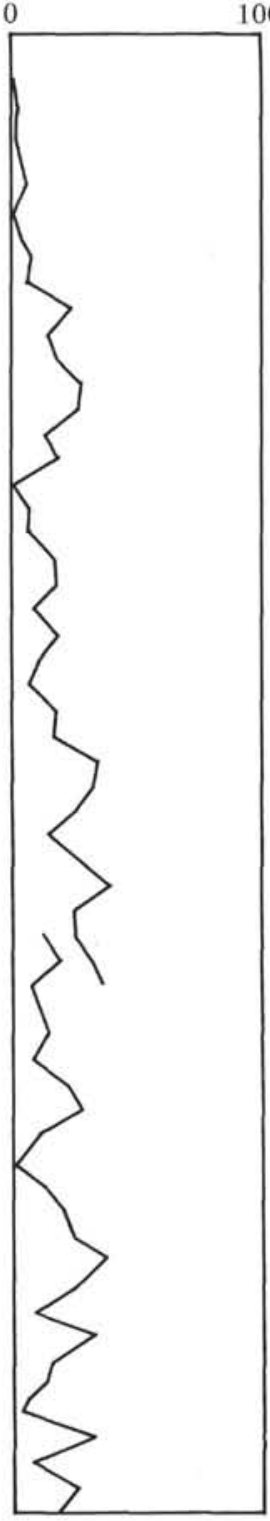

Temperature Indicated by Silicoflagellates percentage $10020^{\circ} \mathrm{C}$
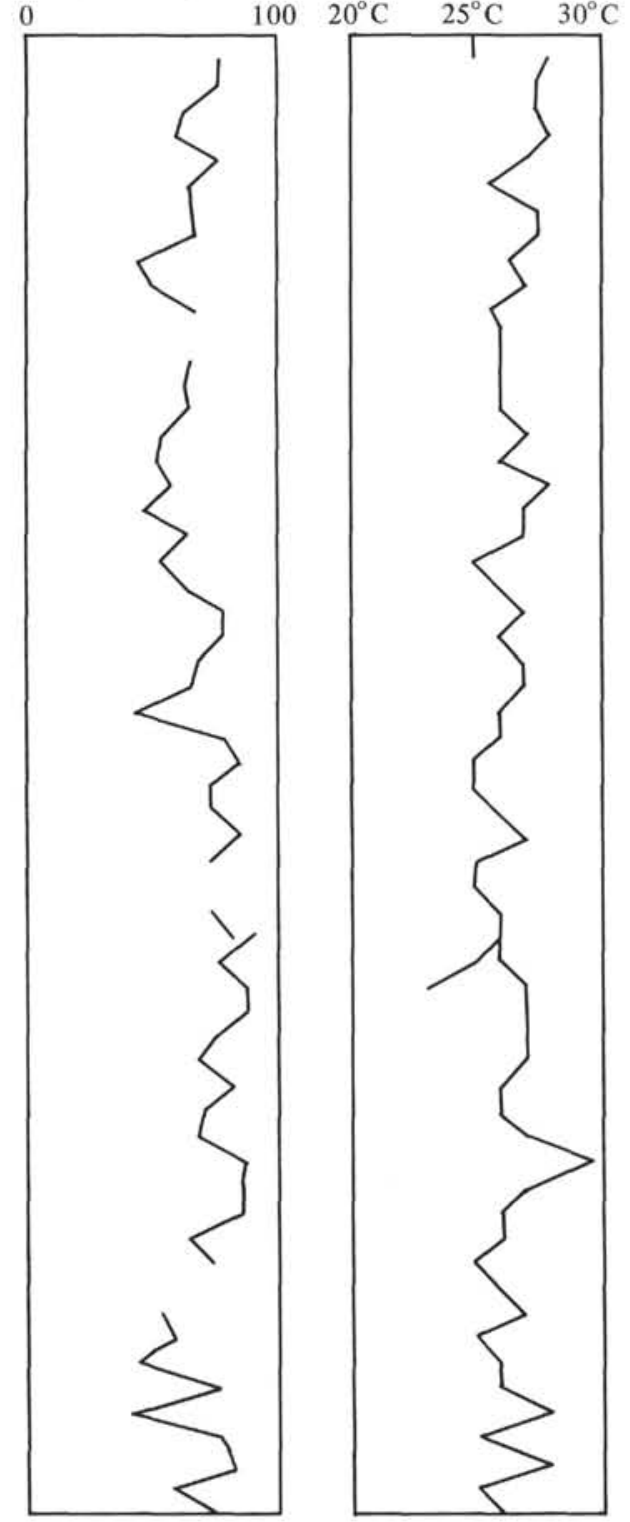

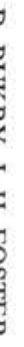


TABLE 7

Percentages of Important Silicoflagellate Species in Panama Basin Cores Compared to Temperatures Indicated by Silicoflagellates and Relative Stratigraphic Position. Peak Abundance of Mesocena elliptica and Cannopilus major Are Associated with Low-Temperature Intervals and Corresponding Low Points in Dictyocha fibula abundance.

Relative Species Abundance

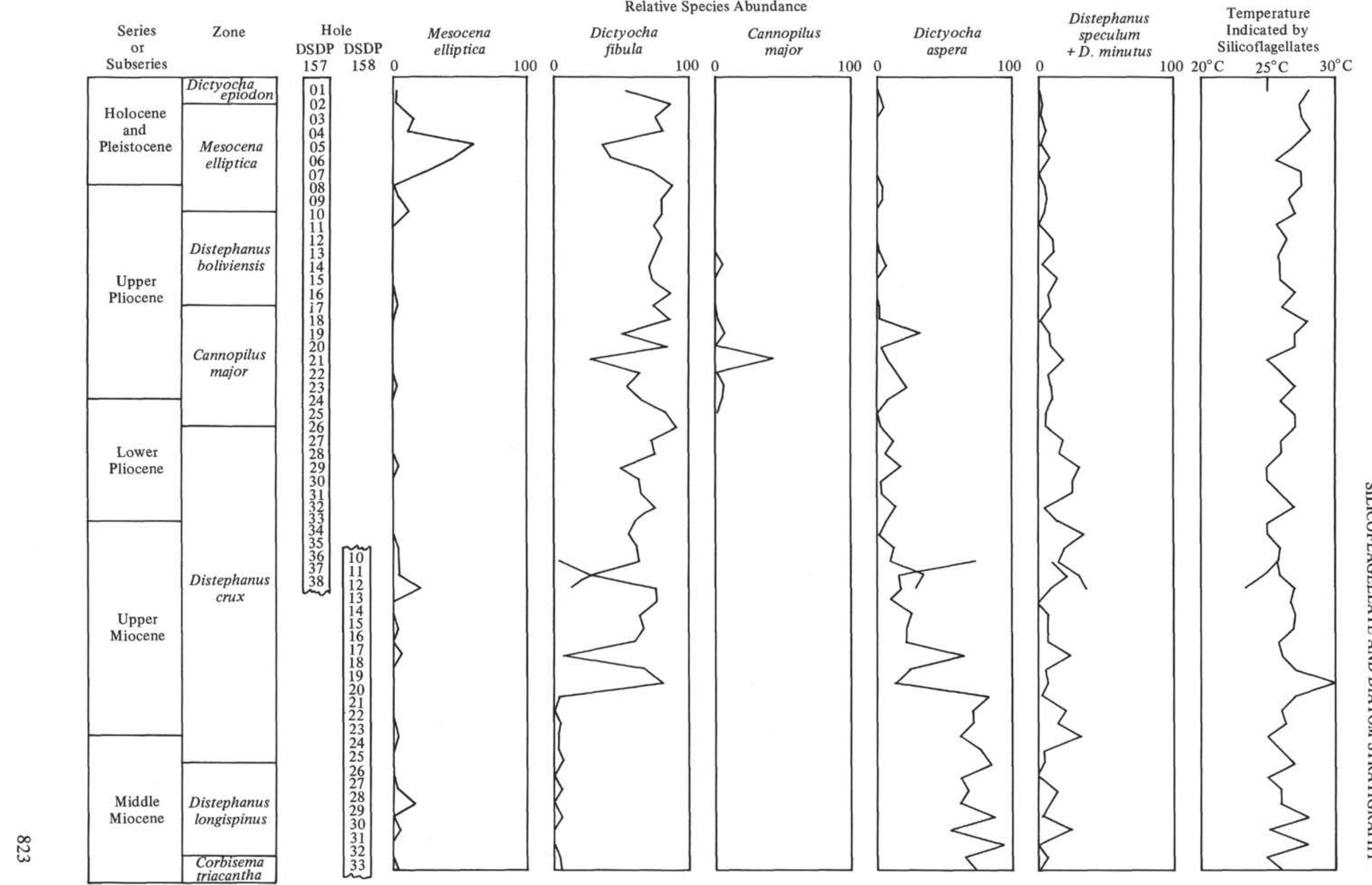

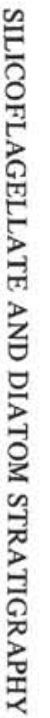


whereas they are restricted to the upper Pliocene in the Panama Basin. Slightly lower temperature is indicated in the upper Pliocene of the Panama Basin by a reduction of the Dictyocha/Distephanus ratio (see preceding section). Similarly, very cool temperatures of 4 to $9^{\circ} \mathrm{C}$ are indicated by this ratio for Ling's North Pacific Miocene Cannopilus -bearing assemblages. The apparent cool-temperature association of Cannopilus suggests that stratigraphic units of the tropics, based on silicoflagellates, are locally useful but may lack chronostratigraphic significance in other regions. The equatorial stratigraphy of the central Pacific suggested by Martini (1971) is most comparable to that observed in the eastern tropical Pacific. The presence of more diverse assemblages in the eastern Pacific, however, allows recognition of some additional biostratigraphic units. The occurrence of some key species in these units is shown in Table 8.

\section{Dictyocha epiodon Zone}

This zone is characterized by the range of Dictyocha epiodon and by the relative abundance of the following other species: dominant Dictyocha fibula, common D. epiodon, and rare D. aspera, Distephanus crux, Mesocena elliptica, and Octactis pulchra.

The first common occurrence of $D$. epiodon in tropical sediment of late Pleistocene age and its common preservation provide a convenient guide to this zone. Reference sections for this zone are Hole DSDP 157, Cores 1 and 2, and Hole DSDP 157A, Cores 1A to 3A.

\section{Mesocena elliptica Zone}

This zone is characterized by the common to abundant presence of Mesocena elliptica and Dictyocha fibula. Distephanus quinquangellus, D. speculum, D. crux, and Octactis pulchra are meager to rare. The two-species domination of the assemblage is very distinctive. The upper limit of the zone is defined by the first consistent occurrence of Dictyocha epiodon, the lower limit by the first post-Miocene common occurrence of $M$. elliptica, which also coincides with the highest common Distephanus boliviensis and with the first occurrence of Octactis pulchra.

The predominance of Mesocena elliptica in middle Pleistocene assemblages of the tropical Pacific has been demonstrated by Jousé (1969) and by Hays et al. (1969). This concentration prompted Hays et al. to note that $M$. elliptica could be used as a guide fossil. Our cores partly support this finding because the greatest abundance of $M$. elliptica occurs in the middle Pleistocene. However, the range of the species encompasses at least the majority of the Pleistocene and the uppermost part of the Pliocene. The Pleistocene range of $M$. elliptica (junior synonym = M. quadrangula) led Martini (1971) to define an upper Pliocene to Holocene " $M$. quadrangula Zone" based on the total range of $M$. elliptica. evidence from DSDP Leg 16 , however, shows that upper Miocene populations of M.elliptica exist. The name and definition of Martini's zone has therefore been emended. A reference section for the Mesocena elliptica Zone includes Cores 3 to 10 of DSDP 157.

TABLE 8

Zonal Occurrence of Some Key Upper Cenozoic Silicoflagellates in the Eastern Pacific Ocean. Consistent Occurrences are Indicated by an X, Sporadic Occurrences by a Dash.

\begin{tabular}{|c|c|c|c|c|c|c|c|c|c|c|c|c|c|c|c|c|c|c|}
\hline & & \multicolumn{17}{|c|}{ Taxa } \\
\hline Age & Zone & 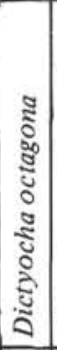 & 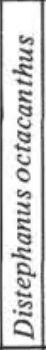 & 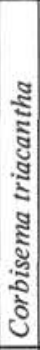 & 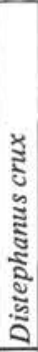 & 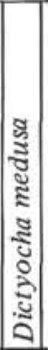 & 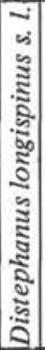 & 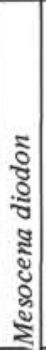 & 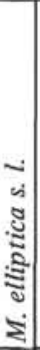 & 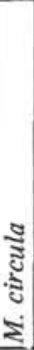 & 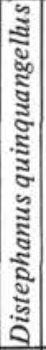 & 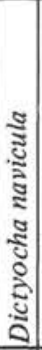 & 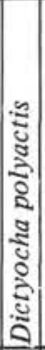 & 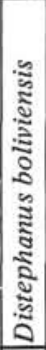 & 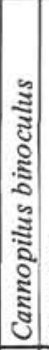 & 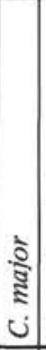 & 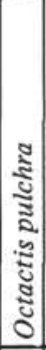 & 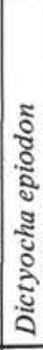 \\
\hline \multirow{2}{*}{$\begin{array}{l}\text { Pleistocene } \\
\text { and } \\
\text { Holocene }\end{array}$} & $\begin{array}{l}\text { Dictyocha } \\
\text { epiodon }\end{array}$ & & & - & $\begin{array}{l}- \\
-\end{array}$ & & & & $\begin{array}{l}- \\
-\end{array}$ & & - & - & & & & & $\begin{array}{l}\mathrm{x} \\
\mathrm{x}\end{array}$ & $\begin{array}{l}\mathrm{X} \\
\mathrm{X}\end{array}$ \\
\hline & $\begin{array}{l}\text { Mesocena } \\
\text { elliptica }\end{array}$ & & & & - & & & & $\begin{array}{l}X \\
X\end{array}$ & & \begin{tabular}{l|}
- \\
-
\end{tabular} & - & & & & & \begin{tabular}{l|}
$\mathrm{X}$ \\
$\mathrm{X}$
\end{tabular} & - \\
\hline \multirow{2}{*}{ Pliocene } & $\begin{array}{c}\text { Distephanus } \\
\text { boliviensis }\end{array}$ & & & - & - & & & & -1 & - & $\begin{array}{l}- \\
-\end{array}$ & & & \begin{tabular}{l|}
$\mathrm{X}$ \\
$\mathrm{X}$
\end{tabular} & - & - & & \\
\hline & $\begin{array}{c}\text { Cannopilus } \\
\text { major }\end{array}$ & & & & - & & & & $\begin{array}{l}- \\
-\end{array}$ & - & \begin{tabular}{|l|}
- \\
-
\end{tabular} & - & & - & \begin{tabular}{|l|}
- \\
-
\end{tabular} & $\begin{array}{l}\mathrm{X} \\
\mathrm{X}\end{array}$ & & \\
\hline \multirow{4}{*}{ Miocene } & $\begin{array}{l}\text { Distephanus } \\
\text { crux }\end{array}$ & & & - & $\begin{array}{l}X \\
X\end{array}$ & - & -1 & & $\begin{array}{l}\mathrm{X} \\
\mathrm{X}\end{array}$ & $\begin{array}{l}X \\
X\end{array}$ & $\begin{array}{l}- \\
-\end{array}$ & - & - & - & & & & \\
\hline & $\begin{array}{l}\text { Distephanus } \\
\text { longispinus }\end{array}$ & & & & $\begin{array}{l}\mathrm{X} \\
\mathrm{X} \\
\end{array}$ & $\begin{array}{l}- \\
- \\
\end{array}$ & \begin{tabular}{l|}
$\mathrm{X}$ \\
$\mathrm{X}$ \\
\end{tabular} & $\bar{x}$ & $\begin{array}{l}\mathrm{X} \\
- \\
\end{array}$ & $\begin{array}{l}\mathrm{X} \\
- \\
\end{array}$ & & & & & & & & \\
\hline & $\begin{array}{l}\text { Corbisema } \\
\text { triacantha }\end{array}$ & & & $\begin{array}{l}\mathrm{X} \\
\mathrm{X}\end{array}$ & $\begin{array}{l}\mathrm{X} \\
\mathrm{X}\end{array}$ & - & \begin{tabular}{l|}
$\mathrm{X}$ \\
$\mathrm{X}$
\end{tabular} & $\begin{array}{l}\mathrm{X} \\
\mathrm{X}\end{array}$ & - & & & & & & & & & \\
\hline & $\begin{array}{l}\text { Distephanus } \\
\text { octacanthus }\end{array}$ & $\mathrm{x}$ & $\mathrm{x}$ & - & $\mathrm{X}$ & & & & & & & & & & & & & \\
\hline
\end{tabular}


This zone is characterized by the common presence of the large, distinctive species, Distephanus boliviensis. Dictyocha fibula is dominant; other meager to rare but consistently present species include Distephanus quinquangellus, D. speculum, and Dictyocha aspera. The top of the zone is indicated by the last common Distephanus boliviensis and by the first common occurrence of post-Miocene Mesocena elliptica. The base of the zone is indicated by the highest consistent occurrences of Cannopilus sp. and Distephanus minutus and by a general increase in the abundance of D.boliviensis. Cores 11 to 17 of DSDP 157 provide a reference section.

\section{Cannopilus major Zone}

This zone is characterized by the consistent presence of species of Cannopilus, with C. major most prominent. Dictyocha fibula is dominant, and D. aspera, Distephanus boliviensis, D. minutus, D. speculum, and Mesocena circula are present in lesser numbers. The top of the zone is marked by the last consistent occurrence of Cannopilus, and the base by the first consistent occurrence of both Distephanus boliviensis s.s. and Cannopilus.

The upper Pliocene occurrence of Cannopilus in the tropical Pacific Ocean was indicated by Jousé (1969). Owing to their large size, subdivided apical rings, and limited stratigraphic range in the eastern tropical Pacific, these forms provide excellent zonal markers. Cores 18 to 26 at DSDP 157 are a reference section for the zone.

\section{Distephanus crux Zone}

This zone is characterized by the consistent presence of Distephanus crux, D. minutus, D. speculum, Dictyocha aspera, and $D$. fibula. Other species present sporadically through the zone are Dictyocha navicula, Distephanus boliviensis s. 1., D. polyactis, and D. quinquangellus. The top of the zone is indicated by the first occurrence of the Cannopilus major group, the first consistent $D$. boliviensis s.s., and by the last consistent occurrence of $D$. crux. The base of the zone is indicated by the last common occurrence of Distephanus longispinus or $D$. sp. cf. D. longispinus, which approximates the earliest occurrence of $D$. quinquangellus. This long zone can be subdivided into an upper Dictyocha fibula Subzone and a lower Dictyocha aspera Subzone on the basis of relative abundances. In the upper subzone, $D$. fibula is usually more abundant than $D$. aspera, and $D$. navicula is more abundant than below. In the lower subzone, D. aspera is typically more abundant than D. fibula. Also, Mesocena diodon and Miocene Mesocena elliptica are more numerous than above. Mesocena diodon is apparently restricted to the lower subzone. The chronostratigraphic value of these subzones is limited, as the reversal in dominance between $D$. aspera and $D$. fibula occurs in the upper Discoaster quinqueramus Zone of coccoliths at DSDP 157 and in the upper Discoaster neohamatus Zone of coccoliths at DSDP 158. Cores 10 to 24 at DSDP 158 and Cores 27 to 38 at DSDP 157 provide reference sections for the Distephanus crux Zone.
This zone is characterized by the consistent meager to common occurrence of Corbisema triacantha in conjunction with abundant Dictyocha aspera and meager to common D. fibula, D. medusa, Distephanus crux, D. longispinus s. 1., and D. speculum. The top of the zone is marked by the last consistent occurrence of $C$. triacantha in the presence of $D$. longispinus s. 1 . All higher occurrences are rare and sporadic, with $D$. longispinus missing. The base of the zone is indicated by the last consistent occurrences of two distinctive eight-spined species, Dictyocha octagona and Distephanus octacanthus. This zone was described by Martini (1971) in cores from the central equatorial Pacific that were assigned to the lower(?) to middle Miocene. The occurrence of this zone within the middle Miocene Discoaster exilis Zone of coccoliths at the base of the Leg 16 Panama Basin section and at the Experimental Mohole section supports this assignment.

\section{Distephanus octacantha Zone}

This zone is characterized by the abundant occurrence of Distephanus octacanthus and Dictyocha octagona. Other members of the assemblage include Corbisema triacantha, Dictyocha aspera, D. fibula, and Distephanus crux. This zone is distinguished from the overlying Corbisema triacantha Zone by the dominance of both $D$. octacanthus and $D$. octagona over $C$. triacantha and by the lack of Distephanus longispinus. The top of the zone is distinguished by the last common occurrence of $D$. octacanthus and $D$. octagona and by the earliest local occurrence of $D$. longispinus. Because this unit has been seen only at the base of the Experimental Mohole section, the base of the zone is unknown.

\section{Taxonomic Usage}

In the past, a combination of trinomial and even quadrinomial systematics with a repetitive use of the same or similar names has made silicoflagellate taxonomy and recombinations difficult. In the system of taxonomy presented in this report, binomial usage is preferred.

Only six genera are used in this report. Cannopilus includes all forms with subdivided apical rings. Corbisema includes all forms with triangular body rings and simple, three-strut central structures. Dictyocha includes all other forms with simple strut structures or struts with an apical bar. Distephanus includes all forms with an open apical ring. Mesocena includes all forms possessing only a body ring with no central structures. Octactis, possibly a special octasymmetric form of Distephanus, has only a vestigial apical structure.

\section{SILICOFLAGELLATE SYSTEMATIC PALEONTOLOGY}

Specific literature references to all silicoflagellate taxa published through 1967 have been indexed by Loeblich et al., 1968. The sources of silicoflagellate taxonomy are given fully in that work, therefore full synonymies are not given here.

\section{Genus CANNOPILUS Haeckel, 1887}

\section{Cannopilus binoculus (Ehrenberg) Lemmermann, 1901} (Plate 1, Figures 1-2)

Remarks: This species is characterized by a large apical ring that is symmetrically divided by a bar into two openings. The basal ring is 
hexagonal and symmetric in Panama Basin specimens. Cannopilus binoculus, owing to its occurrence and large size, seems related to the Cannopilus major group.

\section{Cannopilus ernstinae Bachmann, 1962}

Remarks: Forms assigned to this species in Table 3 have a long spine atop the apical complex. They are identified only in side view (see pl. 1, fig. b. in Loeblich et al., 1968) and may be side views of Cannopilus major specimens. They are noted only in upper Pliocene samples from DSDP 157.

\section{Cannopilus hemisphaericus (Ehrenberg) Haeckel, 1887} (Plate 1, Figure 3)

Remarks: The irregular multi-punctate apical structure, which is closely appressed to the basal ring, characterizes this species. It is distinguished from Cannopilus major by its lack of large portals between struts connecting apical and basal rings.

Cannopilus major (Frenguelli) n. comb. (Plate 1, Figures 4-7; Plate 7, Figure 4)

Dictyocha boliviensis var. major Frenguelli, 1951, p. 277, figs. 3a-c.

Remarks: This especially large species is classified as a Cannopilus owing to the subdivided nature of the apical ring. Specimens having three to seven openings within the apical ring, and showing no particular symmetry, occur in the upper Pliocene of DSDP 157. The basal ring is typically six- or seven-sided.

A single example of two silicoflagellate skeletons that are juxtaposed involves forms that are here classified as two species Cannopilus major and Distephanus boliviensis (Frenguelli) $\mathrm{n}$. comb. If this pairing represents the product of a single cell, the classification key for the genus Cannopilus employed here would be clearly artificial. However, the pairing was observed only in a sample where the ranges of these two species overlap. Distephanus boliviensis has a longer range, which suggests that the pairing could be fortuitous. As the skeletal variability of naturally reproducing silicoflagellate populations is not fully understood, Cannopilus may have been derived from Distephanus as a result of ecologic threshold factors, as yet unknown.

Stratigraphically, Cannopilus major is restricted in Panama Basin cores to a short interval in the upper Pliocene. Because of its large size and distinctive structure, it provides a convenient guide to the Cannopilus major Zone. Jousé (1971) indicated that Distephanus speculum var. cannopiloides [invalid according to Loeblich et al., 1968, p. 48] = ?Cannopilus major occurs in the upper Pliocene of paleomagnetically dated Core V20-119 $\left(47^{\circ} 57^{\prime} \mathrm{N}\right.$., $168^{\circ} 47^{\prime} \mathrm{E}$.) but not in the overlying Pleistocene. In addition, Ling (1970) included forms with Cannopilus hemisphaericus that are here considered Cannopilus major and that occur in the Miocene of North Pacific Ocean cores.

The restricted upper Pliocene range of Cannopilus major in the Panama Basin suggests that it may have flourished there during a period of slightly cooler water, because the paleotemperature indicated by the Dictyocha/Distephanus ratio is relatively low in the upper Pliocene.

\section{Cannopilus quintus Bukry and Foster, n. sp.} (Plate 1, Figures 8-9; Plate 2, Figure 1)

Description: This fossil species is characterized by an essentially symmetric pentagonal basal ring having distal spines at the apices, and by a large apical ring divided into four asymmetric openings.

Remarks: Cannopilus quintus is distinguished from other species of Cannopilus by having a pentagonal basal ring and four asymmetric openings within the apical ring. Distephanus quinquangellus has a pentagonal basal ring but lacks the four openings within the apical ring. The trivial name signifies the five-sided basal ring, an unusual character for Cannopilus.

Occurrence: Cannopilus quintus is presently known only from a lower upper Pliocene sample from the Panama Basin.

Size: Apical ring diameter 32-38 microns. Basal ring diameter 50-58 microns.

Holotype: USNM 182794 (Plate 1, Figures 8-9).

Paratype: USNM 182795.

Type locality: DSDP 157-22(CC), approximate subbottom depth 207 m, Carnegie Ridge, Panama Basin.
Cannopilus schulzii Deflandre, 1962

(Plate 2, Figure 2)

Remarks: This species has an eight-sided basal ring. It was not tabulated because of a single occurrence in the Panama Basin samples.

\section{Genus CORBISEMA Hanna, 1928}

\section{Corbisema triacantha (Ehrenberg) Hanna, 1931}

(Plate 2, Figure 3)

Remarks: The triangular body ring of this species has rounded apices with distal spines at each apex. This species flourishes in the middle Miocene of the Pacific [see Table 5 on EM samples and Martini, 1971, on Leg 7 cores]. The basal silicoflagellate sample from DSDP 158, Core 33 , is at the upper range of this acme, which is very pronounced in the EM cores. Higher occurrences are rare.

\section{Genus DICTYOCHA Ehrenberg, 1837}

\section{Dictyocha aspera (Lemmermann) n. comb.} (Plate 2, Figures 4-6)

Dictyocha fibula var. aspera Lemmermann, 1901, p. 260, pl. 10, figs. 27, 28.

Remarks: This simple, long-ranging species is characterized by having the apical bar aligned with the short axis of the basal ring instead of with the long axis as in Dictyocha fibula. The length of the apical bar varies considerably, causing differences in the size of the short-axis portals with respect to the larger long-axis portals. Numerous synonyms exist for this species; among them are Dictyocha ausonia Deflandre, Dictyocha fibula var. brevispina Lemmermann, D. mutabilis Deflandre, and Dictyocha fibula var. aspera forma rhombica Schulz [see Loeblich et al., 1968].

Stratigraphically, this species occurs consistently in Miocene to Pleistocene sections examined and is missing in older sections. Bachmann (1970) found it missing in an upper Oligocene assemblage from Austria. Martini (1971) proposed a reversal in dominance between Dictyocha aspera and Dictyocha fibula as a potentially useful stratigraphic datum. Study of our Panama Basin sections suggests that this reversal does occur in the late Miocene but is probably controlled environmentally because it occurs at two different times between our northern and southern sites. Although the reversal does not represent a chronostratigraphic datum, it provides a general guide to the upper and lower parts of the Distephanus crux Zone.

\section{Dictyocha epiodon Ehrenberg, 1844}

(Plate 2, Figures 7-8)

Remarks: This Pleistocene species is characterized by an eight-sided basal ring having four major spines and four alternate pikes; the opposing spines are slightly offset, and the apical bar is canted at an angle to the principal axes of the basal ring. No spine occurs on the apical bar, but there are generally four proximally directed pikes on the basal ring near the distally directed pikes.

The common occurrence of this species in upper cores from the Panama Basin and its absence in the underlying section provide a useful guide for the Dictyocha epiodon Zone.

Ehrenberg's illustration of Holocene Dictyocha epiodon from the North Atlantic $\left(54^{\circ} 17^{\prime} \mathrm{N}\right.$., $22^{\circ} 33^{\prime} \mathrm{W}$.) is accepted as the type of this species, and Dictyocha fibula var. aculeata (Lemmermann) is considered a probable junior synonym [compare illustrations of both in pl. 9 of Loeblich et al., 1968]. A high-latitude occurrence of this form in the Pacific was confirmed by Ling (1970), who noted that D. fibula var. aculeata is common in Quaternary cores from the North Pacific. The same form, called Distephanus japonicus, was illustrated by Jousé (1969) from an equatorial Pacific Ocean Pleistocene core $\left(2^{\circ} 01.5^{\prime} \mathrm{S} ., 172^{\circ} 32.5^{\prime} \mathrm{W}\right)$. Dictyocha epiodon is apparently a species tolerant of environmental fluctuations and developed from Dictyocha fibula during the Quaternary.

\section{Dictyocha fibula Ehrenberg, 1839}

(Plate 2, Figure 9; Plate 3, Figures 1 and 12)

Remarks: This species is identified by the alignment of the apical bar with the long axis of the basal ring, instead of with the short axis as in Dictyocha aspera. The apical bar is fairly long in post-Miocene specimens but may be short in the same Miocene samples where $D$. aspera has short apical bars. A specimen of $D$. fibula with auxiliary distal pikes on the basal ring is illustrated (Plate 2, Figure 9) to contrast with the structure 
of D. epiodon (Plate 2, Figure 8), with which it has only general similarity. D. fibula specimens having smooth basal rings are the overwhelmingly predominant form in Panama Basin cores, indicating that possession of distal pikes on the basal ring is not a warm-water character.

Geographically, Dictyocha fibula is cosmopolitan, occurring in oceanic areas at high and low latitudes. Ling (1970) demonstrated that, whereas $D$. fibula is present in core samples from high latitude in the Pacific, it is numerically dominated by Distephanus speculum. In our low-latitude, warm-water assemblages, $D$. fibula is the preeminent species. Though cosmopolitan, $D$. fibula is most successful in warm-water areas. A laboratory-culture study of D. fibula specimens collected near Edmonds, Washington, indicated optimum growth at $10^{\circ} \mathrm{C}$ and 24 per cent salinity (Van Valkenburg and Norris, 1970). As it is unlikely that the temperature of near-surface water inhabited by abundant $D$. fibula populations in the Panama Basin ever fell to $10^{\circ} \mathrm{C}$, a latitudinal series of races of $D$. fibula, each suited to the ambient temperature of the region, probably exists. A repeat of the Van Valkenburg-Norris experiment on cultures of tropical and $\operatorname{arctic} D$. fibula might demonstrate this supposition and show skeletal variation useful in paleoenvironmental interpretation. Would a clonal culture of tropical $D$. fibula produce the group of aberrant skeletons illustrated by Van Valkenburg and Norris? They show forms reminiscent of fossil Dictyocha pentagona and $D$. pseudofibula, which were noted only sporadically in samples from the Panama Basin. Do the fossil Panama Basin occurrences therefore indicate colder waters and lower salinities? Or, are other ecologic factors such as grazing or nitrogen supply chiefly responsible (McGowan, 1971; Tappan, 1971)?

Stratigraphically, Dictyocha fibula ranges throughout the Miocene to Pleistocene sections examined. Bachmann's (1970) upper Oligocene assemblage from Austria lacks $D$. fibula. A reversal in dominance between D. fibula and D. aspera in the upper Miocene (Martini, 1971) provides a general indication of the stratigraphic position of samples within the Distephanus crux Zone.

\section{Dictyocha japonica Deflandre, 1950}

(Plate 3, Figure 3)

Remarks: A single small specimen of this cool-water species was observed in the upper Miocene at DSDP 157.

\section{Dictyocha medusa Haeckle, 1887}

(Plate 3, Figures 4-5)

Remarks: This simple species is characterized by the absence of an apical bar or apical ring. Four struts meet at a central point, forming an $\mathrm{x}$. This species is distinguished from forms of Dictyocha aspera that have a vestigial apical bar by the direct alignment of opposing struts across the center point. Mandra (1968) pointed out the Miocene age of this species under the name Dictyocha staurodon. The present study of sections at DSDP 157, DSDP 157A, DSDP 158, and the Experimental Mohole confirms the restriction of $D$. medusa to the Miocene.

\section{Dictyocha navicula Ehrenberg, 1839}

(Plate 3, Figures 6-8)

Remarks: The form of the body ring is basically elliptical with varying degrees of elongation. The most typical forms in Panama Basin cores are those showing little elongation (Plate 3, Figure 8). Dictyocha navicula is generally rare and sporadic, being common only in sample DSDP 158-11-(CC).

\section{Dictyocha octagona (Tsumura) n. comb.} (Plate 3, Figure 9)

Dictyocha fibula var. octagona Tsumura, 1963, p. 55, 56, 71, pl. 2, fig. 4 ; pl. 10, figs. 11-13; pl. 23, figs. 8-10.

Dictyocha octagona Tsumura, of Martini, 1971, p. 1697, pl. 1, fig. 15.

Remarks: The basal ring of this species is symmetrically octagonal with distal spines at the apices. One pair of opposing spines is distinctly longer than the others. The apical bar is aligned nearly perpendicularly with this pair of spines.

Dictyocha octagona occurs only at the bottom of the Experimental Mohole section and is absent in the stratigraphically higher sections at DSDP 157 and DSDP 158. As it does not consistently range as high as Corbisema triacantha in warm-water Pacific sections, it may be a useful guide to the Distephanus octacanthus Zone.
Dictyocha pentagona (Schulz) n. comb.

(Plate 3, Figure 10)

Dictyocha fibula var. pentagona Schulz, 1928, p. 255, figs. 41a, b. _Loeblich et al., 1968, p. 96, pl. 12, figs. 13, 14.

Remarks: The basal ring of this species is pentagonal and asymmetric, with five equant spines at the apices. The apical bar may be straight or crooked and is connected to the basal ring by five struts of unequal length. This species is rare in the cores examined, but occurrences are noted in the upper Pleistocene, Pliocene, and middle Miocene.

\section{Dictyocha pseudofibula (Schulz) Tsumura, 1963} (Plate 3, Figures 2 and 11)

Remarks: This form is rare and sporadic in our cores and may be an environmentally induced variant of Dictyocha fibula (see Van Valkenburg and Norris, 1970). It is more common in cool-water assemblages at higher latitudes.

\section{Dictyocha vanandelii Bukry and Foster, n. sp. (Plate 7, Figure 1)}

Description: This large species is bilaterally symmetric. The body ring is in the form of a modified ellipse with one end flattened. Three struts meet at the center point of the ellipse dividing the intra-ring area into three portals. Five distal pikes on the body ring are situated at the three apices and at the points where the two long struts meet the body ring.

Remarks: This unusual form is reminiscent of Corbisema owing to the tripartite division of the central area by struts. However, Dictyocha vanandelii is distinguished by having five basal-ring pikes and a modified elliptic outline. Dictyocha tripyla Ehrenberg has a three-part strut system but has four pikes and no flattening of the body ring. This species is named in recognition of the leadership of Dr. Tj. H. van Andel in marine geologic studies of the Panama Basin.

Occurrence: Dictyocha vanandelii is presently known only from DSDP 157-22(CC), which is lower upper Pliocene.

Size: Length and width about 75 microns.

Holotype: USNM 182796 (Plate 7, Figure 1).

Type locality: DSDP 157-22(CC), approximate subbottom depth 207 meters, Carnegie Ridge, Panama Basin.

\section{Genus DISTEPHANUS Stöhr, 1880}

Distephanus boliviensis (Frenguelli) n. comb. (Plate 4, Figures 1-3)

Dictyocha boliviensis Frenguelli, 1940, p. 44, fig. 4._Loeblich et al., 1968 , p. 83 , pl. 9 , fig. 3

Remarks: This especially large species is characterized by equant distal spines on six- or seven-sided basal rings, by an open apical ring, and usually by six of seven proximal pikes on the basal ring. Characteristic forms are most prominent in upper Pliocene samples from DSDP 157 , although smaller forms with less equant spines (resembling Distephanus speculum) occur in the lower Pliocene and upper upper Miocene (Plate 4, Figure 4).

\section{Distephanus crux (Ehrenberg) Haeckle, 1887 (Plate 4, Figures 5-6)}

Remarks: This species has four-part symmetry. The apical opening is typically small. Although Distephanus crux is long-ranging, it is relatively meager in the Panama Basin sections. Its greatest abundance, as much as 90 per cent of some assemblages, has been noted in middle Miocene samples from Maryland and California. Ling (1970) and the present study suggest that Distephanus crux dwindled into obscurity after the end of the Miocene, becoming rare in later epochs. Its great abundance in mid-latitude samples contrasts with its meager to common occurrence in coeval middle Miocene samples from the Panama Basin, suggesting that its optimum growth environment was temperate instead of tropical.

A specimen of Distephanus crux with a basal ring like that of associated Dictyocha epiodon is illustrated (Plate 4, Figure 5). The occasional convergence of basal-ring structures, such as this, between coeval species of Distephanus and Dictyocha suggests close biologic affinities between certain members of these genera. Compare coeval Dictyocha octagona and Distephanus octacanthus illustrated here (Plate 3, Figure 9; Plate 4, Figure 12) and Gemeinhardt's (1930) illustrations of Dictyocha pseudofibula and Dictyocha pseudocrux. 
Distephanus longispinus (Schulz) n. comb. (Plate 4, Figures 7-8)

Distephanus crux f. longispina Schulz, 1928, p. 256, fig. 44._Loeblich et al., 1968 , p. 120 , pl. 24 , fig. 29.

Remarks: This species has a relatively small, somewhat elliptic, quadrate basal ring, a large square apical ring, two extremely long opposed spines, and two short spines. Distephanus sp. cf. D. longispinus has relatively shorter long-axis spines and a smaller apical ring with respect to the basal ring. Stratigraphically, sensu stricto forms are noted only in the middle Miocene EM section. The comparable forms at DSDP 158 are likewise restricted to the Miocene.

\section{Distephanus minutus (Bachmann) n. comb.}

(Plate 4, Figures 10-11)

Dictyocha speculum f. minuta Bachmann in Ichikawa et al., 1967, p. 161, pl. 7, figs. 12-25. L Loeblich et al., 1968, p. 115, pl. 52, figs. 26-39.

Remarks: The apical ring of this hexagonal species is so wide that the struts connecting it to the basal ring are practically covered in plan view. It is most common in middle Miocene to lower Pliocene samples.

Distephanus octacanthus (Desikachary and Maheshwari) n. comb. (Plate 4, Figure 12)

Distephanus crux var. octacanthus Desikachary and Maheshwari, 1956, p. 260 , figs. $10,12,13$; pl. 13, figs. 8 , Loeblich et al., 1968, p. 120 , pl. 24 , figs. $25-27$.

Remarks: This symmetric octagonal form has a small square apical ring that distinguishes it from Dictyocha octagona, with which it occurs in sample EM 7-1, 36-38 cm. It does not occur in younger strata from the EM section, DSDP 157, or DSDP 158.

\section{Distephanus parvus (Bachmann) n. comb.} (Plate 5, Figures 2-3)

Dictyocha crux f. parva Bachmann in Ichikawa et al., 1967, p. 156, pl. 4, figs. 14-31. Loeblich et al., 1968, p. 85, pl. 52, figs. 8-25.

Remarks: A single specimen of Distephanus parvus was observed in upper Miocene sample DSDP 157-38(CC). It is a species with four distal pikes on the apical ring. This species was originally described from the lower upper Miocene of Japan.

\section{Distephanus polyactis (Ehrenberg) Deflandre, 1932}

(Plate 5, Figures 6-7)

Remarks: This large symmetric species is noted rarely in upper Miocene and lower Pliocene cores only from DSDP 157. The ninespined form illustrated as Distephanus speculum by Ling (1970) from North Pacific cores matches our Panama Basin specimens.

Distephanus quinquangellus Bukry and Foster, nomen novum (Plate 5, Figure 4)

Distephanus speculum var. pentagonus Lemmermann, 1901, p. 264, pl. 11, fig. 19. _Loeblich et al., 1968, p. 122, pl. 25, fig. 5. non Distephanus pentagonus Wailes, 1939, p. 10, fig. 23.

Description: This species has symmetric five-sided basal and apical rings with equant spines at the apices of the basal ring. Typically, five small proximally directed pikes occur on the basal ring. Panama Basin specimens have apical ring diameters of $8-18$ microns and basal ring diameters of 20-45 microns.

Remarks: The name Distephanus quinquangellus is used as a substitute for Distephanus speculum var. pentagonus (Lemmermann). Lemmermann's variety is considered to be of species rank but cannot be elevated because the name "Distephanus pentagonus" is occupied by Distephanus pentagonus Wailes.

Occurrence: Distephanus quinquangellus is most common in upper Miocene and Pliocene cores of the Panama Basin but also ranges through the Pleistocene. Only rare Distephanus sp. cf. D. quinquangellus, which are slightly asymmetric, were noted in middle Miocene samples.

\section{Distephanus speculum (Ehrenberg) Haeckle, 1887} (Plate 5, Figure 8)

Remarks: This hexagonal species is distinguished from Distephanus boliviensis by its smaller size, by its two opposing basal-ring spines that are longer than the other four, and by its generally smaller apical ring. Distephanus speculum is distinguished from D. minutus by its much smaller apical ring. Although this long-ranging species occurs throughout the sections examined, it rarely achieves the levels of abundance indicated by Ling (1970) for North Pacific core samples. This presumably cool-water species is most numerous in upper Miocene samples of the Panama Basin. Distephanus speculum and D. minutus constitute the majority of specimens used to determine the Distephanus portion of the Dictyocha/Distephanus ratio for paleotemperature determination (see Mandra, 1969).

\section{Genus MESOCENA Ehrenberg, 1843}

\section{Mesocena circula (Ehrenberg) Ehrenberg, 1844}

(Plate 5, Figure 9; Plate 6, Figure 1)

Remarks: These circular to elliptic rings are ornamented only by a series of regularly or irregularly spaced distally directed pikes. Some regular specimens have one set of pikes directed "upward" and an alternate set directed "downward" with respect to the plane of the ring. Mesocena circula occurs sporadically in the Miocene and Pliocene. Only a few specimens (reworked?) were noted from the Pleistocene.

\section{Mesocena elliptica (Ehrenberg) Ehrenberg, 1844}

(Plate 6, Figures 2-4)

Remarks: The body ring of this species may take a variety of shapes between rhomboid and circular. Four distally directed spines at the apices of rhomboid forms or symmetrically 90 degrees apart on circular forms are a consistent character of this species. The body ring may be smooth or ornamented by irregularly spaced pikes.

Rhomboid and circular forms and smooth and ornamented forms occur together in Quaternary samples, where Mesocena elliptica is particularly abundant. Quaternary specimens as a group are more symmetric than older specimens assigned to this species. Only rare specimens were noted in Pliocene Panama Basin samples; these could represent minor contamination, reworking, or small or poorly preserved populations of $M$. elliptica. The occurrence of $M$. elliptica in upper Miocene samples, indicated in the shipboard Leg 16 report, has been confirmed by shore-laboratory studies. The unusual disjunct distribution of $M$. elliptica is partly explained by the skeletal forms of the Miocene populations. Although single specimens of $M$. elliptica from the Miocene may be identical in form to those of the Quaternary, the Miocene populations show a high percentage of irregular, elongate-rhomboid forms, many of which have one or more margins that are bowed-out or bowed-in. From structural evidence, the Miocene and Quaternary forms could represent two acmes of the same species. Alternately, the rare presence of Mesocena-like Dictyocha fibula specimens (Plate 6, Figure 5) with Miocene $M$. elliptica could indicate derivation from a $D$. fibula stock at two different times.

Stratigraphically, two essentially disjunct, Miocene and Quaternary populations occur in DSDP Leg 16 cores. The youngest middle Quaternary abundance of Mesocena elliptica matches the observations of Hays et al. (1970) and Muhina (1969), which were based on studies of cores from the tropical Pacific and Indian Oceans. Their studies indicated a very short stratigraphic range, and Hays et al. stated that, "Mesocena elliptica is stratigraphically useful, its range bracketing the Jaramillo event for which it is a useful guide fossil." They assigned a radiometric age of $0.927 \mathrm{~m} . \mathrm{y}$. to the base of the Jaramillo normal polarity event. Although $M$. elliptica is most abundant in the middle Quaternary of the Panama Basin cores, it ranges throughout the Quaternary (see Tables 2 and 3). Because little comparative information is available, the stratigraphic significance of the Miocene population is unclear.

\section{Mesocena diodon Ehrenberg, 1844}

(Plate 6, Figures 6-7)

Remarks: This circular to elongate elliptic species has two distal pikes aligned with the major axis of the body ring. Mesocena diodon occurs only in the Miocene part of the sections examined.

\section{Mesocena pentagona Haeckle, 1887}

(Plate 6, Figure 8)

Remarks: This species is bilaterally symmetric, having five distal spines on the body ring. Two specimens, Miocene and Pleistocene, were observed in Panama Basin samples. 
Mesocena triangula (Ehrenberg) Ehrenberg, 1844

(Plate 6, Figures 9-10)

Remarks: This roundly triangular species has distal pikes at the apices and is consistently ornamented with many tiny pikes along the distal margin of the body ring. It occurs rarely in Miocene and Pliocene samples

\section{Genus OCTACTIS Schiller, 1925}

Octactis pulchra Schiller, 1925

(Plate 6, Figures 11-12)

Remarks: This symmetric octagonal species is dominated by the body ring and distal spines. It occurs only rarely in Quaternary samples. It is common in some late Pleistocene and Holocene core samples from the Black Sea (Bukry, unpublished data) and was originally described in living populations from the Adriatic Sea.

\section{DIATOMS}

\section{Study Methods}

Core samples tabulated for diatoms are from the same fractions, greater than 44 microns, used in the silicoflagellate study. These were separated to facilitate study of larger diatoms present at low levels of abundance. Preparations of the fraction less than 44 microns, which are more poorly preserved than the coarse fraction, typically contain common to abundant fragments of the elongate diatom genera Thalassiothrix and Thalassionema and lack many distinctive species characterizing the coarser fractions. In the diatom stratigraphic tabulations and general interpretations, which are based only on the coarse fractions, the letters $A, C, M$, and $R$ indicate the relative abundance of each species (Tables 9,10 , and 11). $A$ is used for abundant occurrences, $C$ for common occurrences, $M$ for meager occurrences (intermediate between common and rare), and $R$ if only one to four specimens are found on a sample slide. Scanning of the $40 \times 20 \mathrm{~mm}$ slide areas was done at magnifications of 100 and $250 \times$.

\section{Paleoenvironmental Interpretation}

All diatom assemblages examined are dominated by oceanic, tropical to subtropical species. Only a single predominantly cool-water species, Coscinodiscus curvatulus Grunow [see Lohman, 1941; Hendey, 1964], has

TABLE 9

Diatoms Greater Than 44 Microns in Size at DSDP 157A

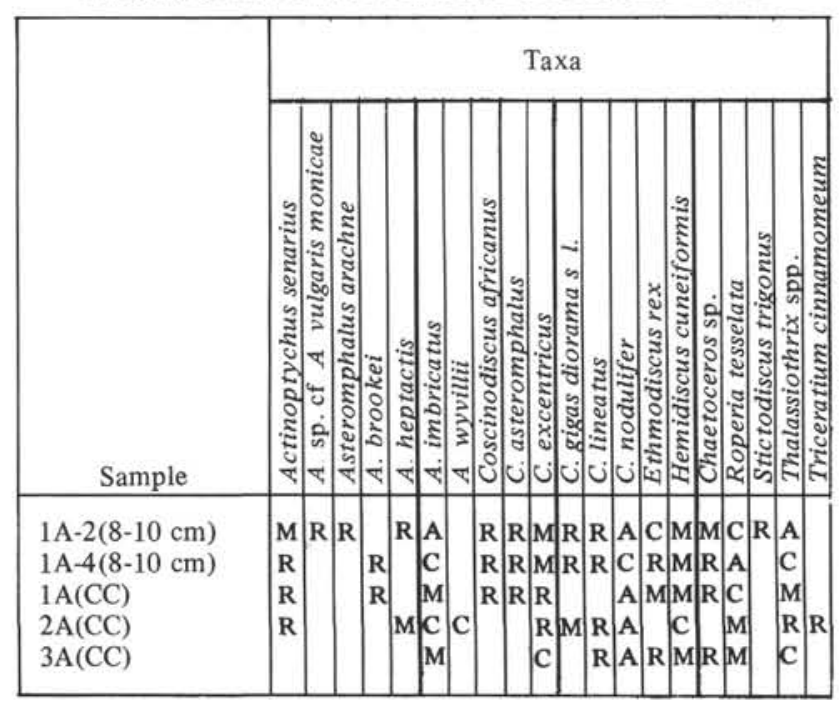

been identified. The consistent dominance of restricted warm-water taxa [Groups I and V of Kanaya and Koizumi, 1966] suggests that the abundance of the elongate diatoms Thalassionema and Thalassiothrix is indicative of upwelling and resultant productivity, not necessarily of cool-water conditions as has been suggested (Hendey, 1937). Both of the principal species of elongate diatoms in the Panama Basin, Thalassionema nitzschioides and Thalassiothrix longissima, have been recorded as minor living components in the Pacific Ocean Subarctic group of Venrick (1971), but not of the Central Pacific group; nutrient enrichment is higher in the Subarctic area. Denticula, a common genus in Neogene high-latitude cool-water assemblages, is missing from all but Miocene assemblages in the Panama Basin. Actual temperature fluctuations in the basin were probably small during the late Neogene. The Miocene and Pliocene occurrences of C. curvatulus and temperate-water Actinocyclus ehrenbergii Ralfs [see Lohman, 1941] indicate that these taxa were then more cosmopolitan, or that Panama Basin waters may have been slightly cooler. Because the sample interval for this study is 9 meters (about 200,000-year increments for the Pleistocene at DSDP 157), short-term incursions of cool-water species might be as yet undetected. The consistent dominance of oceanic, warm-water species in the samples examined is, however, the most significant feature of the Panama Basin diatom assemblages.

Genera that are considered to be characteristic of coastal or nearshore areas can be used to indicate the presence of displaced shallow-water deposits, which may result from erosion during glacial periods of lowered sea level or from turbid-flow deposition. Representatives of such genera-Auliscus, Aulacodiscus, Biddulphia, Diploneis, Grammatophora, Navicula, Pleurosigma, and Surirella - are rare and sporadic in their occurrence, indicating normal pelagic deposition at DSDP 157 and DSDP 158.

The state of preservation varies to some extent and is best reflected by degree of solution and by the relative diversity of the assemblages. For example, no diatoms are present in DSDP 157 below Core 38, which contains hard chert. Diatom silica in deeper sediment was presumably remobilized during formation of the chert, because diversity and preservation of diatoms are fairly good directly above. Hemidiscus cuneiformis is represented by both whole valves and open girdle bands. Although thinning of the areolae structure of valves can be observed in several species, no intermediate stages between open girdle bands and thinned areolae has been observed. No attempt has been made to gauge various degrees of preservation, but Kamatani (1971) has stated that, "The rate of dissolution of diatomaceous silica varies considerably between species." Therefore the species diversity of an assemblage and possibly the percentage of open girdle bands could be combined to estimate a range of preservation states.

\section{Tropical Diatom Zonation}

Biostratigraphic zonation based on oceanic diatom assemblages is a relatively new field. Stratigraphic subdivisions of Pacific Ocean sediment by diatoms have been indicated recently by Kanaya (1971), Kanaya and 
TABLE 10

Diatoms Greater Than 44 Microns in Size at DSDP 157

\begin{tabular}{|c|c|c|c|c|c|c|c|c|c|c|c|c|c|c|c|c|c|c|c|c|c|c|c|c|c|c|c|}
\hline \multirow[b]{2}{*}{$\begin{array}{r}\text { Sample } \\
(\text { All CC) }\end{array}$} & \multicolumn{27}{|c|}{ Taxa } \\
\hline & : & 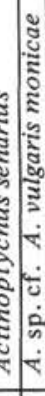 & 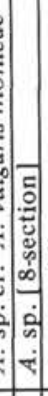 & 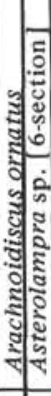 & 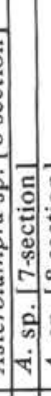 & 馬 & : & & 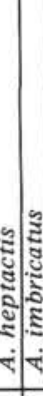 & 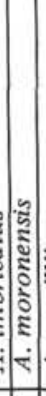 & : & : & 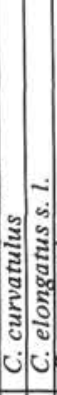 & 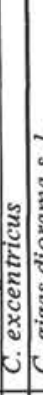 & 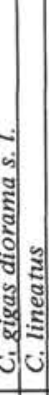 & : & 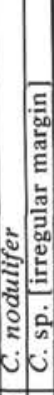 & 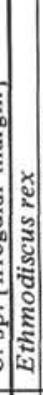 & 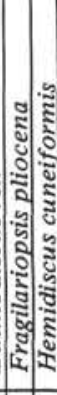 & : & : & 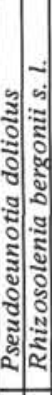 & : & 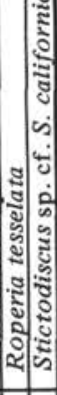 & 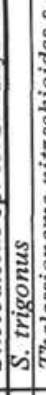 & 竎 & 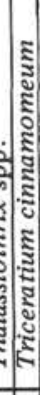 \\
\hline $\begin{array}{l}1(C C) \\
2(C C) \\
3(C C) \\
4(C C) \\
5(C C)\end{array}$ & & \begin{tabular}{l|l}
$R$ & \\
$R$ & $R$ \\
$M$ & $R$
\end{tabular} & $\mathrm{R}$ & R & 1 & & $\begin{array}{l}\mathrm{M} \\
\mathrm{R}\end{array}$ & & \begin{tabular}{l|l}
$\mathrm{R}$ & $\mathrm{C}$ \\
$\mathrm{C}$ & $\mathrm{C}$ \\
$\mathrm{A}$ & $\mathrm{A}$ \\
$\mathrm{C}$ \\
$\mathrm{C}$
\end{tabular} & & $\mathrm{R} F$ & $\mathrm{R}$ & & \begin{tabular}{|l|l}
$\mathrm{M}$ & $\mathrm{N}$ \\
$\mathrm{C}$ & $\mathrm{N}$ \\
$\mathrm{M}$ & $\mathrm{F}$ \\
$\mathrm{C}$ & $\mathrm{N}$ \\
$\mathrm{M}$ & $\mathrm{M}$
\end{tabular} & \begin{tabular}{l|l}
$\mathrm{M}$ & $\mathbf{R}$ \\
$\mathrm{M}$ & $\mathrm{M}$ \\
$\mathbf{R}$ & \\
$\mathrm{M}$ & \\
$\mathrm{R}$ &
\end{tabular} & $\mathbf{R}$ & \begin{tabular}{l|}
$\mathrm{A}$ \\
$\mathrm{A}$ \\
$\mathrm{A}$ \\
$\mathrm{A}$ \\
$\mathrm{A}$
\end{tabular} & $\begin{array}{l}\mathrm{M} \\
\mathrm{M} \\
\mathrm{R} \\
\mathrm{R}\end{array}$ & $\begin{array}{l}\mathrm{M} \\
\mathrm{M} \\
\mathrm{C} \\
\mathrm{R} \\
\mathrm{R}\end{array}$ & $\begin{array}{lll}\mathrm{R} \\
\mathrm{R} \\
\mathrm{R}\end{array}$ & $\mathrm{R}$ & $R$ & $\mid \begin{array}{c}\mathrm{M} \\
\mathrm{M} \\
\mathrm{A} \\
\mathrm{M} \\
\mathrm{M}\end{array}$ & \begin{tabular}{|l|l}
$\mathrm{C}$ & $\mathrm{R}$ \\
$\mathrm{C}$ & \\
$\mathrm{M}$ & \\
$\mathrm{C}$ &
\end{tabular} & $\begin{array}{l}R \\
R \\
R\end{array}$ & & $R$ \\
\hline $\begin{array}{r}6(\mathrm{CC}) \\
7(\mathrm{CC}) \\
8(\mathrm{CC}) \\
9(\mathrm{CC}) \\
10(\mathrm{CC})\end{array}$ & & \begin{tabular}{l|l}
$R$ & $R$ \\
$R$ & \\
$M$ & \\
$R$ &
\end{tabular} & \begin{tabular}{|l|}
$\mathrm{R}$ \\
$\mathrm{R}$
\end{tabular} & $\begin{array}{l}\mathrm{R} \\
\mathrm{M} \\
\mathrm{M}\end{array}$ & 4 & & & & \begin{tabular}{l|l}
$\mathbf{R}$ & $\mathrm{M}$ \\
$\mathrm{R}$ & $\mathrm{M}$ \\
$\mathrm{R}$
\end{tabular} & $\begin{array}{lll}\mathrm{A} \\
\mathrm{A}\end{array}$ & & $M$ & & $\begin{array}{l}\mathrm{C} \\
\mathrm{C} \\
\mathrm{M} \\
\mathrm{M}\end{array}$ & $\begin{array}{l}\mathrm{M} \\
\mathrm{M} \\
\mathrm{R} \\
\mathbf{M}\end{array}$ & 1. & \begin{tabular}{|l|}
$\mathrm{C}$ \\
$\mathrm{A}$ \\
$\mathrm{A}$ \\
$\mathrm{M}$ \\
$\mathrm{A}$
\end{tabular} & $\begin{array}{l}\mathrm{M} \\
\mathrm{M} \\
\mathrm{M}\end{array}$ & \begin{tabular}{|l|l}
$R$ & $R$ \\
$R$ & $R$ \\
$R$ \\
$R$ \\
$M$ \\
$M$
\end{tabular} & \begin{tabular}{|l|l|}
$\mathrm{R}$ & $\mathrm{R}$ \\
$\mathrm{M}$ & $\mathrm{M}$ \\
\end{tabular} & & $R / R$ & $\mid \begin{array}{l}\mathrm{M} \\
\mathrm{M} \\
\mathrm{M} \\
\mathrm{M} \\
\mathrm{M} \\
\mathrm{C}\end{array}$ & \begin{tabular}{|l|l|}
$M$ & \\
$R$ & $R$ \\
$R$ & \\
$M$ & \\
\end{tabular} & & $\begin{array}{l}\mathrm{A} \\
\mathrm{A} \\
\mathrm{R} \\
\mathrm{A}\end{array}$ & \\
\hline $\begin{array}{l}11(\mathrm{CC}) \\
12(\mathrm{CC}) \\
13(\mathrm{CC}) \\
14(\mathrm{CC}) \\
15(\mathrm{CC}) \\
\end{array}$ & $\mathrm{R}$ & $\begin{array}{l}\mathrm{C} \\
\mathrm{R} \\
\mathrm{M} \\
\mathrm{C}\end{array}$ & & $\begin{array}{l}\mathrm{R} \\
\mathrm{R} \\
\mathrm{R} \\
\mathrm{R} \\
\mathrm{R}\end{array}$ & ? & $\mathbf{R}$ & $\mathrm{R}$ & & \begin{tabular}{l|l}
$\mathrm{R}$ & $\mathrm{R}$ \\
$\mathrm{R}$ & $\mathrm{M}$ \\
$\mathrm{R}$ \\
$\mathrm{M}$ \\
$\mathrm{R}$
\end{tabular} & a. & & \begin{tabular}{l|l|}
$M$ & $C$ \\
$R$ & \\
$R$ & $M$ \\
$R$ & \\
\end{tabular} & & \begin{tabular}{|l|}
$\mathrm{M}$ \\
$\mathrm{C}$ \\
$\mathrm{R}$ \\
$\mathrm{R}$ \\
$\mathrm{C}$
\end{tabular} & $\begin{array}{l}\mathrm{M} \\
\mathrm{R} \\
\mathrm{M} \\
\mathrm{M} \\
\mathrm{A} \\
\end{array}$ & a & \begin{tabular}{l|}
$\mathrm{A}$ \\
$\mathrm{A}$ \\
$\mathrm{A}$ \\
$\mathrm{A}$ \\
$\mathrm{C}$
\end{tabular} & $\begin{array}{l}\mathrm{R} \\
\mathrm{R} \\
\mathrm{R} \\
\mathrm{C} \\
\end{array}$ & $\begin{array}{l}\mathrm{A} \\
\mathrm{M} \\
\mathrm{M} \\
\mathrm{M} \\
\mathrm{C}\end{array}$ & \begin{tabular}{|l|l|}
$\mathrm{A}$ & \\
$\mathrm{M}$ & \\
$\mathrm{M}$ & \\
$\mathrm{M}$ & \\
$\mathrm{C}$ & $\mathrm{R}$ \\
\end{tabular} & & & $\begin{array}{l}\mathrm{M} \\
\mathrm{M} \\
\mathrm{M} \\
\mathrm{M} \\
\mathrm{M}\end{array}$ & $R$ & & \begin{tabular}{|l|l}
$\mathrm{M}$ \\
$\mathrm{M}$ \\
$\mathrm{M}$ \\
$\mathrm{R}$ \\
$\mathrm{R}$
\end{tabular} & R \\
\hline $\begin{array}{l}16(\mathrm{CC}) \\
17(\mathrm{CC}) \\
18(\mathrm{CC}) \\
19(\mathrm{CC}) \\
20(\mathrm{CC})\end{array}$ & $\begin{array}{l}\mathrm{R} \\
\mathrm{M} \\
\mathrm{M}\end{array}$ & $\begin{array}{l}M \\
C \\
R \\
R\end{array}$ & & $R \mid \begin{array}{l}R \\
M\end{array}$ & $\mathbf{M} \mathbf{R}$ & & $\begin{array}{l}\mathrm{M} \\
\mathrm{R} \\
\mathrm{C} \\
\mathrm{R}\end{array}$ & $\mathbf{R}$ & \begin{tabular}{l|l}
$\mathrm{R}$ & $\mathrm{R}$ \\
$\mathrm{M}$ & $\mathrm{R}$ \\
$\mathrm{C}$ & $\mathrm{N}$ \\
$\mathrm{R}$ & $\mathrm{C}$ \\
$\mathrm{N}$
\end{tabular} & $\mathrm{R}$ & $\mathrm{R}$ & $\mathbf{R}$ & \begin{tabular}{|l|l}
$R$ & \\
$R$ & $R$ \\
$R$ & $R$ \\
\end{tabular} & \begin{tabular}{|l|}
$\mathrm{C}$ \\
$\mathrm{C}$ \\
$\mathrm{M}$ \\
$\mathrm{M}$ \\
$\mathrm{M}$
\end{tabular} & $\begin{array}{l}\text { C } \\
\text { C } \\
\text { C } \\
\text { A } \\
\text { C }\end{array}$ & ל. & \begin{tabular}{l|}
$\mathrm{C}$ \\
$\mathrm{A}$ \\
$\mathrm{A}$ \\
$\mathrm{C}$ \\
$\mathrm{C}$
\end{tabular} & $\begin{array}{l}\mathrm{M} \\
\mathrm{C} \\
\mathrm{C} \\
\mathrm{R} \\
\mathrm{R}\end{array}$ & $\begin{array}{ll}\mathrm{M} \\
\mathrm{M} \\
\mathrm{A} \\
\mathrm{A} \\
\mathrm{R}\end{array}$ & \begin{tabular}{l|l|l}
$M$ & $R$ \\
$M$ & \\
$A$ & $R$ \\
$A$ & $R$ \\
$R$ & $M$ \\
\end{tabular} & $\mathrm{R}$ & & $\begin{array}{l}c \\
c \\
c \\
c \\
c\end{array} \mid$ & & & M & 4 \\
\hline $\begin{array}{l}21(\mathrm{CC}) \\
22(\mathrm{CC}) \\
23(\mathrm{CC}) \\
24(\mathrm{CC}) \\
25(\mathrm{CC})\end{array}$ & $\begin{array}{l}\mathbf{R} \\
\mathrm{R}\end{array}$ & $\begin{array}{l}\mathrm{R} \\
\mathrm{R} \\
\mathrm{R} \\
\mathrm{R} \\
\mathrm{R}\end{array}$ & & $\mathbf{R}$ & 8 & & $\begin{array}{l}\mathbf{R} \\
\mathrm{M} \\
\mathrm{M} \\
\mathrm{R}\end{array}$ & & $\begin{array}{r}\mathrm{R} \\
\mathrm{R} \\
\mathrm{R} \\
\mathrm{C} \\
\mathrm{C} \\
\mathrm{C} \\
\mathrm{N}\end{array}$ & R & & $\begin{array}{l}\mathrm{R} \\
\mathrm{R} \\
\mathrm{R}\end{array}$ & $\begin{array}{l}\mathrm{R} \\
\mathrm{R} \\
\mathrm{A} \\
\mathrm{M}\end{array}$ & $|\mathrm{R}|$ & $\begin{array}{l}\mathrm{C} \\
\mathrm{M} \\
\mathrm{A} \\
\mathrm{M} \\
\mathrm{M}\end{array}$ & a. & \begin{tabular}{l|}
$\mathrm{A}$ \\
$\mathrm{A}$ \\
$\mathrm{C}$ \\
$\mathrm{C}$ \\
$\mathrm{A}$
\end{tabular} & $\begin{array}{l}\mathrm{R} \\
\mathrm{M} \\
\mathrm{M} \\
\mathrm{R} \\
\mathrm{C}\end{array}$ & \begin{tabular}{|l|l} 
& $C$ \\
$R$ & $A$ \\
$R$ & $C$ \\
$M$ & $M$ \\
$M$ & $M$
\end{tabular} & \begin{tabular}{l|l|}
$\mathrm{C}$ & $\mathrm{R}$ \\
$\mathrm{A}$ & \\
$\mathrm{C}$ & \\
$\mathrm{M}$ & \\
\end{tabular} & R & $\mathrm{R}$ & $\begin{array}{l}\mathrm{C} \\
\mathrm{C} \\
\mathrm{M} \\
\mathrm{M} \\
\mathrm{M}\end{array}$ & 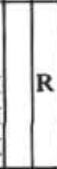 & & $M \mid \begin{array}{l}\mathrm{C} \\
\mathrm{C} \\
\mathrm{C} \\
\mathrm{C} \\
\mathrm{M}\end{array}$ & $R$ \\
\hline $\begin{array}{l}26(\mathrm{CC}) \\
27(\mathrm{CC}) \\
28(\mathrm{CC}) \\
29(\mathrm{CC}) \\
30(\mathrm{CC})\end{array}$ & \begin{tabular}{l|}
$\mathrm{R}$ \\
$\mathrm{M}$ \\
$\mathrm{R}$ \\
$\mathrm{R}$ \\
$\mathrm{M}$ \\
\end{tabular} & $\begin{array}{l}\mathbf{R} \\
\mathrm{R} \\
\mathrm{C}\end{array}$ & & R & $R$ & $\begin{array}{l}\mathrm{R} \\
\mathrm{R}\end{array}$ & $\mathrm{R}$ & $\begin{array}{l}\mathrm{R} \\
\mathrm{R}\end{array}$ & \begin{tabular}{l|l}
$\mathrm{R}$ & $\mathrm{R}$ \\
$\mathrm{R}$ & $\mathrm{C}$ \\
$\mathrm{R}$ & $\mathrm{R}$ \\
$\mathrm{R}$ & $\mathrm{R}$ \\
\end{tabular} & \begin{tabular}{|l|l|}
$R$ & \\
$R$ & \\
$R$
\end{tabular} & & $\begin{array}{l}\mathbf{R} \\
\mathbf{R}\end{array}$ & \begin{tabular}{|l|l|}
$M$ & \\
$A$ & $R$ \\
$M$ & $R$ \\
$R$ & $R$ \\
& $R$ \\
\end{tabular} & $\begin{array}{l}\mathrm{C} \\
\mathrm{C} \\
\mathrm{R} \\
\mathrm{R}\end{array}$ & $\begin{array}{l}\mathrm{R} \\
\mathrm{M} \\
\mathrm{C} \\
\mathrm{R} \\
\mathrm{R}\end{array}$ & \begin{tabular}{l|l|} 
& \\
& \\
2 &
\end{tabular} & \begin{tabular}{|l|}
$\mathrm{C}$ \\
$\mathrm{M}$ \\
$\mathrm{C}$ \\
$\mathrm{A}$
\end{tabular} & $\begin{array}{l}\mathrm{M} \\
\mathrm{R} \\
\mathrm{M} \\
\mathrm{C} \\
\mathrm{C}\end{array}$ & \begin{tabular}{|l|l}
$R$ & $R$ \\
$R$ & $C$ \\
$M$ & $C$ \\
$R$ & $R$ \\
& $M$
\end{tabular} & $\begin{array}{l}\mathrm{R} \\
\mathrm{C} \\
\mathrm{C} \\
\mathrm{R} \\
\mathrm{M}\end{array}$ & $\mathrm{R}$ & \begin{tabular}{|l|l|l}
$R$ & $R$ \\
\end{tabular} & $\mid \begin{array}{l}\mathrm{M} \\
\mathrm{C} \\
\mathrm{C} \\
\mathrm{M} \\
\mathrm{M}\end{array}$ & 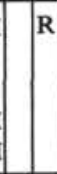 & & \begin{tabular}{l|l}
$\mathrm{M}$ & $\mathrm{M}$ \\
$\mathrm{C}$ \\
$\mathrm{R}$ \\
$\mathrm{C}$ \\
$\mathrm{C}$ \\
$\mathrm{M}$ \\
$\mathrm{R}$
\end{tabular} & $\begin{array}{ll}R \\
R \\
R\end{array}$ \\
\hline $\begin{array}{l}31(\mathrm{CC}) \\
32(\mathrm{CC}) \\
33(\mathrm{CC}) \\
34(\mathrm{CC}) \\
35(\mathrm{CC})\end{array}$ & \begin{tabular}{|l|}
$\mathrm{M}$ \\
$\mathrm{C}$ \\
$\mathrm{R}$
\end{tabular} & & & & & $\mathbf{R}$ & & $\mathbf{R}_{\mathbf{R}}$ & $\mathbf{R}$ & 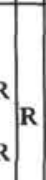 & & $M \mid \begin{array}{l}R \\
R\end{array}$ & \begin{tabular}{|l}
$\mathrm{R}$ \\
$\mathrm{R}$ \\
$\mathrm{R}$ \\
$\mathrm{R}$
\end{tabular} & $\begin{array}{l}\mathrm{R} \\
\mathrm{R}\end{array}$ & $\begin{array}{l}\mathrm{R} \\
\mathrm{M} \\
\mathrm{M} \\
\mathrm{R} \\
\mathrm{R}\end{array}$ & , & $\begin{array}{l}\mathrm{M} \\
\mathrm{C} \\
\mathrm{A} \\
\mathrm{A} \\
\mathrm{M}\end{array}$ & $\begin{array}{l}\mathrm{M} \\
\mathrm{M} \\
\mathrm{R} \\
\mathrm{R}\end{array}$ & \begin{tabular}{l|l}
$\mathrm{M}$ \\
$\mathrm{A}$ \\
$\mathrm{C}$ \\
$\mathrm{C}$ \\
$\mathrm{M}$ \\
$\mathrm{M}$ \\
$\mathrm{C}$ & $\mathrm{M}$ \\
$\mathrm{M}$
\end{tabular} & $\begin{array}{l}\mathrm{M} \\
\mathrm{C} \\
\mathrm{M} \\
\mathrm{M}\end{array}$ & $\mathrm{R}$ & & $\begin{array}{l}\mathrm{M} \\
\mathrm{R} \\
\mathrm{M} \\
\mathrm{C}\end{array}$ & & & $\mathrm{R} \mid \begin{array}{l}\mathrm{A} \\
\mathrm{C} \\
\mathrm{A} \\
\mathrm{A}\end{array}$ & $\begin{array}{l}\mathrm{M} \\
\mathrm{M} \\
\mathrm{R}\end{array}$ \\
\hline $\begin{array}{l}36(\mathrm{CC}) \\
37(\mathrm{CC}) \\
38(\mathrm{CC})\end{array}$ & $\begin{array}{l}\mathrm{R} \\
\mathrm{R}\end{array}$ & & & & & & & & $\mathbf{R}$ & & & & $\begin{array}{l}\mathrm{R} \\
\mathrm{M} \\
\mathrm{R}\end{array}$ & $\begin{array}{l}\mathrm{R} \\
\mathrm{R}\end{array}$ & $\begin{array}{l}\mathrm{R} \\
\mathrm{R}\end{array}$ & $\mathrm{M}$ & \begin{tabular}{|l|l}
$\mathrm{C}$ & $\mathrm{R}$ \\
$\mathrm{A}$ & $\mathrm{R}$ \\
$\mathrm{M}$ &
\end{tabular} & & \begin{tabular}{|l|l}
$M$ & $C$ \\
$M$ & $R$ \\
$M$ & $R$
\end{tabular} & & & \begin{tabular}{|l|l}
$R$ & $R$ \\
$R$
\end{tabular} & $\begin{array}{l}\mathrm{R} \\
\mathrm{R} \\
\mathrm{R}\end{array}$ & & & \begin{tabular}{l|l}
$\mathrm{R}$ & $\mathrm{M}$ \\
$\mathrm{C}$ & $\mathrm{C}$ \\
$\mathrm{C}$ & $\mathrm{C}$
\end{tabular} & $\begin{array}{l}R \\
R \\
R\end{array}$ \\
\hline
\end{tabular}

Koizumi (1970), Jousé (1969), Muhina (1969), Donahue (1970), and Burckle (1969). As a result of their particular attention to the biogeographic distribution of diatoms, the stratigraphic studies published by Kanaya, Koizumi, Jousé, Kozlova, and Muhina have been especially helpful.

Previous studies of warm-water Pacific Ocean diatom stratigraphy have been limited to certain parts of the upper Cenzoic, owing to the core material available. The most outstanding contribution is the study by Kanaya
(1971) of Miocene cores from the Experimental Mohole near Guadalupe Island. Two of the numbered zones described there are directly recognizable in Panama Basin cores. Other helpful studies include Kolbe (1954) and Hays et al. (1969).

Van Hinte (1969) has correctly emphasized that biostratigraphic zones should be defined by their fossil content, not by lithostratigraphic type sections. But the reference sections of oceanic strata listed with newly 
TABLE 11

Diatoms Greater Than 44 Microns in Size at DSDP 158

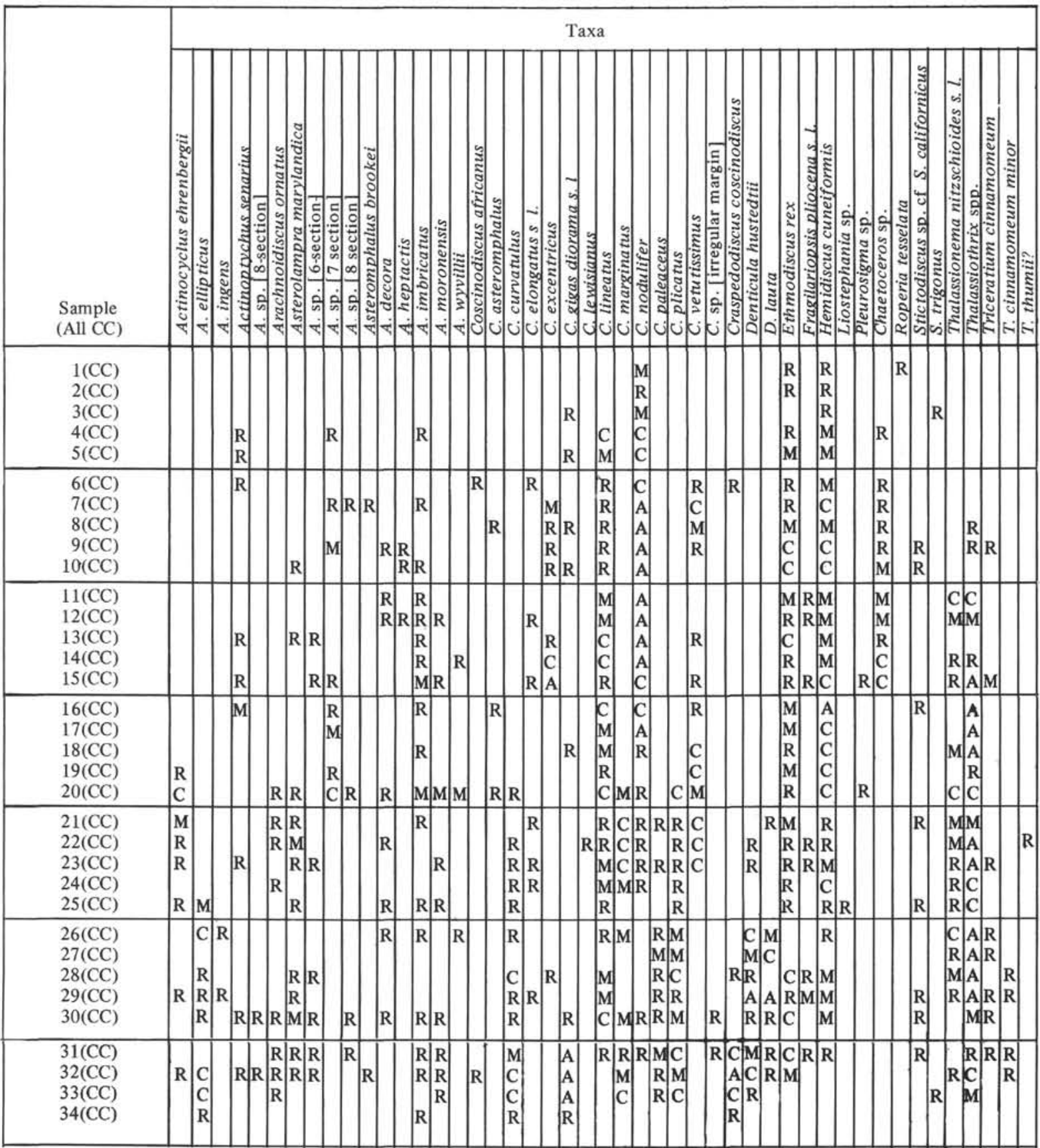

defined zones do provide a useful basis for future investigators to assess specific local sedimentologic, preservational, and drilling factors. Zones are described mainly on the basis of large, easily identified members of the fossil diatom assemblages. The occurrence of some key species in these zones is shown in Table 12.

\section{Roperia tesselata Zone}

This zone is characterized by the range of common Roperia tesselata. Other longer-ranging species that are common to abundant include Asteromphalus imbricatus, Coscinodiscus nodulifer, and Thalassiothrix spp. Among the less numerous long-ranging species, Coscinodiscus excentricus predominates over $C$. lineatus and Chaetoceros sp. this relation is noted in both the Panama Basin (DSDP 157) and the west flank of the East Pacific Rise (DSDP 159). Among rare taxa, only six-sectioned forms of Asterolampra occur. Rare Stictodiscus trigonus is present.

The occurrence of Roperia tesselata is a convenient guide for the zonal assemblage. Taxa characteristic of lower zones that are absent or rare in the coarse-fraction assemblage include Asteromphalus decorus, Fragilariopsis pliocena, and Thalassionema nitzschioides. Fine-fraction assemblages of the zone contain Pseudoeunotia doliolus, 
TABLE 12

Zonal Occurrence of Some Key Upper Cenozoic Diatoms in the Eastern Pacific. Consistent Occurrences are Indicated by an X, Sporadic Occurrences by a Dash.

\begin{tabular}{|c|c|c|c|c|c|c|c|c|c|c|c|c|c|c|c|c|c|c|c|c|c|c|}
\hline & & \multicolumn{21}{|c|}{ Taxa } \\
\hline Age & Zone & 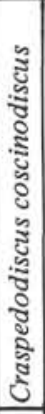 & 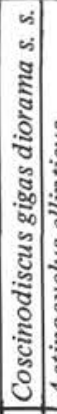 & 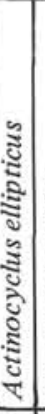 & 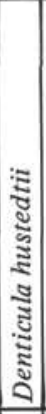 & 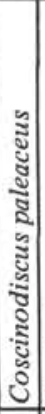 & 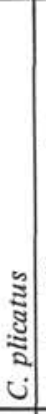 & 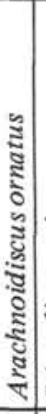 & 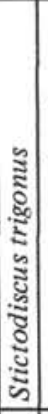 & 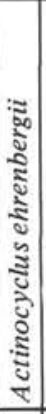 & 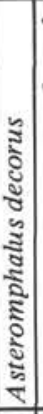 & 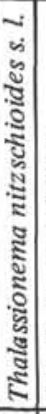 & 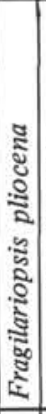 & 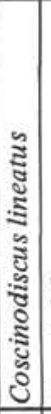 & . & 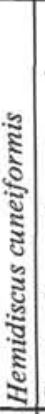 & 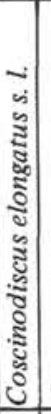 & 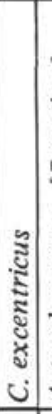 & 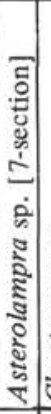 & 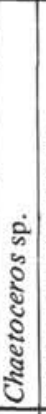 & 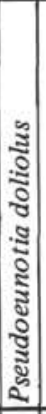 & 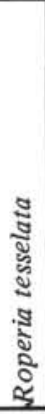 \\
\hline \multirow{2}{*}{$\begin{array}{c}\text { Holocene } \\
\text { and } \\
\text { Pleistocene }\end{array}$} & $\begin{array}{l}\text { Roperia } \\
\text { tesselata }\end{array}$ & & & & & & & & - & & & & & $\begin{array}{l}\mathrm{X} \\
\mathrm{X}\end{array}$ & $\begin{array}{l}\mathrm{x} \\
\mathrm{x}\end{array}$ & $\begin{array}{l}\mathrm{X} \\
\mathrm{X}\end{array}$ & & $\begin{array}{l}\mathrm{x} \\
\mathrm{x}\end{array}$ & & $\begin{array}{l}\mathrm{X} \\
\mathrm{X}\end{array}$ & - & $\begin{array}{l}\mathrm{X} \\
\mathrm{X}\end{array}$ \\
\hline & $\begin{array}{c}\text { Chaetoceros } \\
\text { sp. }\end{array}$ & & & & & & & & & $\mathrm{X}$ & - & $\mathrm{X}$ & $\begin{array}{l}\mathrm{X} \\
\mathrm{X}\end{array}$ & $\begin{array}{l}\mathrm{X} \\
\mathrm{X} \\
\end{array}$ & $\begin{array}{l}\mathrm{X} \\
\mathrm{x}\end{array}$ & $\begin{array}{l}\mathrm{X} \\
\mathrm{X}\end{array}$ & $\mathrm{x}$ & \begin{tabular}{l|}
$\mathrm{X}$ \\
$\mathrm{x}$
\end{tabular} & - & $\begin{array}{l}\mathrm{x} \\
\mathrm{X}\end{array}$ & - & - \\
\hline \multirow[t]{2}{*}{$\begin{array}{c}\text { Late } \\
\text { Miocene }\end{array}$} & $\begin{array}{l}\text { Hemidiscus } \\
\text { cuneiformis }\end{array}$ & & & & & & & & & - & & - & & \begin{tabular}{|l|}
$\mathrm{X}$ \\
$\mathrm{X}$ \\
\end{tabular} & \begin{tabular}{l|}
$\mathrm{x}$ \\
- \\
\end{tabular} & $\begin{array}{l}\mathrm{X} \\
\mathrm{X}\end{array}$ & & & \begin{tabular}{l|l}
$\mathrm{X}$ \\
$\mathrm{X}$
\end{tabular} & & & \\
\hline & $\begin{array}{l}\text { Coscinodiscus } \\
\text { plicatus }\end{array}$ & & - & $\mathrm{X}$ & $\bar{x}$ & $\bar{x}$ & $\begin{array}{l}\mathrm{X} \\
\mathrm{X}\end{array}$ & $\begin{array}{l}\mathrm{X} \\
-\end{array}$ & & $\begin{array}{l}\mathrm{X} \\
-\end{array}$ & $\begin{array}{l}- \\
-\end{array}$ & $\begin{array}{l}\mathrm{X} \\
\mathrm{X}\end{array}$ & - & $\begin{array}{l}\mathrm{x} \\
\mathrm{X}\end{array}$ & - & $\begin{array}{l}\mathrm{X} \\
\mathrm{X}\end{array}$ & $\begin{array}{l}- \\
-\end{array}$ & & $\mathrm{x}$ & & & \\
\hline $\begin{array}{l}\text { Middle } \\
\text { Miocene }\end{array}$ & $\begin{array}{l}\text { Craspedodiscus } \\
\text { coscinodiscus }\end{array}$ & $\begin{array}{l}\mathrm{X} \\
\mathrm{X}\end{array}$ & $\begin{array}{l}\mathrm{X} \\
\mathrm{X}\end{array}$ & $\begin{array}{l}\mathrm{X} \\
\mathrm{X}\end{array}$ & $\begin{array}{l}\mathrm{X} \\
\mathrm{X}\end{array}$ & $\begin{array}{l}\mathrm{X} \\
\mathrm{X}\end{array}$ & $\begin{array}{l}\mathrm{X} \\
\mathrm{X}\end{array}$ & $\begin{array}{l}\mathrm{X} \\
\mathrm{X}\end{array}$ & - & - & & - & - & - & - & - & & & & & & \\
\hline
\end{tabular}

Rhizosolenia bergonii, and Thalassiosira oestrupii. The rare but distinctive species Stictodiscus trigonus occurs in this zone and in the much lower Craspedodiscus coscinodiscus Zone, but is not observed at intervening levels. This zone occurs at DSDP 157A, Cores 1A to 3A; DSDP 157 , Cores 1 to 5 , probably also Cores 6 to 9 ; and in the top sample at DSDP 159.

\section{Chaetoceros sp. Zone}

This zone is bounded by the first common occurrence of Chaetoceros sp. at the base and by the first common occurrence of Roperia tesselata at the top. The disappearance of Coscinodiscus elongatus (lanceolate and typical forms) near the middle of the zone helps to distinguish an upper and a lower part. Asteromphalus is common in the upper part of the zone, whereas Thalassionema is most common in the lower part. The most common and consistently present species throughout the zone, besides Chaetoceros sp., are Coscinodiscus lineatus, $C$. nodulifer, Ethmodiscus rex, Hemidiscus cuneiformis, and Thalassiothrix spp. The highest local occurrences of several taxa are noted in the upper part of the zone: Actinocyclus ehrenbergii, Asterolampra spp. having seven or eight sections, and Asteromphalus decorus.

Changes in tropical diatom assemblages near the first occurrence of Chaetoceros sp. include (a) the first occurrence of seven-sectioned Asterolampra sp. and Asteromphalus heptactis, (b) the earliest consistent Coscinodiscus excentricus and $C$. nodulifer, and (c) the latest occurrences of Denticula hustedtii, D. lauta, Coscinodiscus paleaceus, and $C$. plicatus. Reference sections with representative assemblages of the zone are at DSDP 158, Cores 1 to 15 , and DSDP 157 , Cores 7 to 38 .

\section{Hemidiscus cuneiformis Zone}

Between the uppermost Coscinodiscus plicatus and the lowermost Chaetoceros sp., this zone is recognized as a short interval in which Hemidiscus cuneiformis, Thalassiothrix, and Coscinodiscus lineatus are common. Coscinodiscus nodulifer, a dominant species in tropical fossil assemblages (Kolbe, 1954) first becomes numerically significant within this zone. Cores 16 to 19 at DSDP 158 contain representative assemblages of the zone.

\section{Coscinodiscus plicatus Zone}

This zone is characterized by the overlapping ranges of Coscinodiscus plicatus and Hemidiscus cuneiformis in the absence of Craspedodiscus coscinodiscus. Typical members of the zonal assemblage include Actinocyclus ellipticus, Coscinodiscus curvatulus, $C$. lineatus, $C$. paleaceus, Denticula hustedtii, D. lauta, Thalassionema spp., and Thalassiothrix spp.

This zone has been well typified by Kanaya (1971) as Zone III in his study of diatoms from the EM site. Equatorial Pacific reference cores assigned to this zone include Cores 20 to 30 at DSDP 158.

\section{Craspedodiscus coscinodiscus Zone}

This zone is distinguished by an assemblage containing abundant Coscinodiscus gigas diorama s.s., common to abundant Craspedodiscus coscinodiscus, common Actinocyclus ellipticus, Coscinodiscus curvatulus, and Denticula hustedtii. Absent from the assemblage except for rare specimens at the top are Coscinodiscus lineatus and Hemidiscus cuneiformis. The top of the zone is identified 
by the disappearance of $C$. gigas diorama s.s. and $C$. coscinodiscus and by the earliest occurrences of $H$. cuneiformis, Coscinodiscus nodulifer, and Asteromphalus decorus. The base of the zone is not present in DSDP Leg 16 cores, but, as indicated by Kanaya (1971) in his discussion of the essentially equivalent Zone II in the EM cores, the last common occurrence of Coscinodiscus lewisianus provides a convenient guide, which might serve as a marker species for the next lower zonal unit. This criterion would likely be applicable to tropical areas because a single reworked(?) specimen of this species was observed at DSDP 158 (Plate 13, Figure 7). Assemblages from Cores 31 to 33 of DSDP 158 are considered representative of this zone.

\section{Diatom Taxonomic Usage}

The names for diatoms in this report have been based on illustrations and descriptions in the following publications: Castracane, 1886; Cupp, 1943; Hanna, 1932; Jousé, 1968; Kanaya, 1971; Kanaya and Koizumi, 1966; Koizumi, 1968; Kolbe, 1954; Lohman, 1941; Muhina, 1969; Reinhold, 1937; and Wornardt, 1967.

\section{DIATOM SPECIES TABULATED}

\section{Actinocyclus ehrenbergii Ralfs (Plate 8, Figures 1-2)}

Following the usage of Hanna (1932), forms with varying numbers of rays are included. This species occurs through the middle Miocene to upper Pliocene sections at DSDP 157 and DSDP 158. It is missing in Pleistocene samples, and in the middle Pliocene at DSDP 157, it is most common in the fine fraction.

\section{Actinocyclus ellipticus Grunow} (Plate 8, Figure 3)

This thick species exhibits high interference colors. It is restricted to middle Miocene cores of the Panama Basin where it is commonly a conspicuous member of the assemblages.

\section{Actinocyclus ingens Rattray}

(Plate 8, Figure 4)

This species occurs rarely only in middle Miocene samples from the Panama Basin but is recorded as a common species in both middle and upper Miocene samples from Experimental Mohole cores about 20 degrees farther north (Kanaya, 1971).

\section{Actinoptychus senarius Ehrenberg (Plate 8, Figures 7-9)}

This cosmopolitan species occurs throughout the Panama Basin cores but is most common in upper Pliocene sediment at DSDP 157. It is considered a subtropical species (Lohman, 1941).

\section{Actinoptychus sp. cf. A. vulgaris monicae Grunow (Plate 8, Figure 10)}

Specimens referred to this twelve-compartment species generally show no areolation structures preserved, unlike those specimens illustrated by Wornardt (1967). It occurs only rarely in Pleistocene cores at DSDP 157.

\section{Actinoptychus sp. [8-section]} (Plate 8, Figure 11)

Alternate compartments of this form have matching substructure producing a formée-cross pattern. It is only rarely present in Pleistocene and middle Miocene samples.

\section{Arachnoidiscus ornatus Ehrenberg} (Plate 8, Figure 6)

This species is recorded only rarely; most occurrences are in the middle to upper Miocene, and the specimens are fragmented.

\section{Asterolampra marylandica Ehrenberg \\ (Plate 9, Figures 3-4)}

Only forms composed of five sections are assigned to this species. Frustules occur intact in several samples. This species is missing at DSDP 157, in the Pliocene and Pleistocene, but occurs consistently in the middle to upper Miocene at DSDP 158. Its highest sporadic occurrence is in the upper Miocene.

\section{Asterolampra sp. [6-section] (Plate 9, Figure 5)}

This symmetric six-section form is the most numerous and longranging Asterolampra, occuring regularly in the middle Miocene to Pleistocene of the Panama Basin.

\section{Asterolampra sp. [7-section]}

(Plate 9, Figure 6)

This form occurs sporadically only in the upper Miocene to upper Pliocene.

$$
\begin{gathered}
\text { Asterolampra sp. [8-section] } \\
\text { (Plate 10, Figure 1) }
\end{gathered}
$$

Eight-section varieties of Asterolampra occur only sporadically in middle Miocene to upper Pliocene cores of DSDP 157 and DSDP 158. Hendey (1937) reported it only near the equator.

\section{Asteromphalus arachne (Brebisson) \\ (Plate 10, Figures 2-3)}

This small, asymmetric, five-section species is thinly constructed and has developed practically no hyaline central area. Rare sporadic occurrences are noted only in the upper Miocene to Pleistocene at DSDP 157.

\section{Asteromphalus brookei (Ehrenberg) (Plate 10, Figures 4-5)}

This species is intermediate between Asteromphalus heptactis and $A$. imbricatus, having eight to ten sections. It occurs mainly in the Pliocene section at DSDP 157.

$$
\begin{gathered}
\text { Asteromphalus decorus (Greville) n. comb. } \\
\text { (Plate 10, Figures 6-9) }
\end{gathered}
$$

Asterolampra decora Greville, 1862, Quat. Jour. Micr. Sci., n.s., v. 2, p. 45 , pl. 7, figs. 4-6.

Asterolampra decora Greville, var. nov. Castracane, 1886, Bot. Chall.

Exp., pt. 4, p. 136, pl. 16, fig. 9.

This small- to medium-sized species has a complex central hyaline area more comparable to Asteromphalus than to the simple Asterolampra. It occurs sporadically through the Miocene and Pliocene sections in the Panama Basin. The circular central area shows a wide variety of complexity. Simplest forms have an inner cycle ranging from two to eight sections and have an adjacent cycle of eight to eighteen sections. More complex forms lack orderly central area cycles (see Castracane, 1886).

\section{Asteromphalus heptactis (Brebisson) \\ (Plate 11, Figures 1-2)}

This species is restricted here to only seven-section forms, although eight-section forms show the same general proportions. It first occurs in the upper Miocene nannofossil Discoaster quinqueramus Zone of DSDP 157 and DSDP 158 and is missing at the older EM site to the north.

\section{Asteromphalus imbricatus Wallich \\ (Plate 11, Figures 3-4)}

This long-ranging tropical species is restricted to forms having eleven to twenty-two sections. Pleistocene and Pliocene specimens from DSDP 157 tend to have subcircular central areas with a single recurved umbilical section line connecting the two appressed punctate areas (Plate 11, Figure 4). Miocene specimens from DSDP 158 have circular central areas and commonly more than one recurved umbilical section line (Plate 11, Figure 3), a character reminiscent of Castracane's (1886) illustration of "Asterolampra grevillei (Wall.) Grev., var. eximia, nov." Although occurring throughout our cores from DSDP 157 and DSDP 158 , this species is most abundant in the late Pleistocene. 


\section{Asteromphalus moronensis (Greville)}

(Plate 11, Figures 5-6)

This circular species is typically constructed in ten sections. It is distinctive in having a convex sulcate margin to the hyaline central area. Some specimens are slightly asymmetrical. This form is sporadic in the present cores, but as indicated by Kanaya (1971) and Kolbe (1954), it is most typical of the middle and upper Miocene, coincident with Coscinodiscus plicatus.

\section{Asteromphalus wyvillii Castracane (Plate 12, Figure 1)}

This large species is characterized by a complex central area and punctate sections that number more than twenty-two. In Panama Basin cores, forms with as many as thirty-two sections occur. It is typically rare and sporadic, being numerically important only in Pleistocene sample $157 \mathrm{~A}-2 \mathrm{~A}(\mathrm{CC})$.

\section{Chaetoceros sp.}

(Plate 15, Figures 6-8)

Complete specimens of this unusual species-shaped like a shepard's crook having a small cup at the end of the staff opposite the hook-were observed in several samples. The rare complete specimens in our Panama Basin cores show that the small cuplike valve at the end of the staff is very thin and therefore probably susceptible to both dissolution and breakage, either during deposition in the ocean or during subsequent laboratory preparation of samples. The hollow staff is nonperforate and apparently resistant to dissolution. It has nodular surface ornamentation, which on some specimens shows a spiralling pattern reminiscent of a candy cane. The Panama Basin form ranges from middle upper Miocene to upper Pleistocene. The consistnet and common occurrence of this species make it a useful late Cenozoic guide taxon.

\section{Coscinodiscus africanus Janisch \\ (Plate 12, Figure 2)}

This distinctive species is identified by the small, off-center circlet containing non-radial areolae and by the lines of small areolae that radiate away from the circlet. This warm-water species is found sporadically in Pleistocene and Pliocene cores. Rare isolated Miocene specimens are also noted.

\section{Coscinodiscus asteromphalus Ehrenberg (Plate 12, Figure 3)}

As illustrated in Wornardt (1967), this large species has regularly sized, radially aligned areolae and a central rosette of enlarged areolae. It occurs sporadically in upper Miocene and higher cores.

\section{Coscinodiscus curvatulus Grunow}

(Plate 12, Figures 4-5)

This species is characterized by the slight curvature of its longest lines of areolae, which extend from the center to the periphery, and by the shorter lines of areolae inclined between these. It occurs in coarse fractions from Panama Basin cores only in Miocene and Pliocene sediment. Its disappearance at DSDP 158 suggests a distinctive change in the sedimentary environment above Miocene Core 20 because its range at DSDP 157 extends into the upper Pliocene (to Core 17). This is one of the few large species in the Panama Basin assemblages that is considered to be primarily a cool-water or boreal indicator (Kanaya and Koizumi, 1966; and Lohman, 1941).

\section{Coscinodiscus elongatus Grunow \\ (Plate 12, Figures 6-8)}

In addition to the form with concave sides illustrated by Reinhold (1937), forms with straight and rounded convex sides are also included here. No specimens with rhomboid outlines (see Coscinodiscus lancelotus in Kanaya, 1971) were noted. C. elongatus occurs fairly consistently from the middle Miocene to the upper Pliocene. Its reduction along with the earliest sporadic Roperia tesselata in the Panama Basin cores can be used to mark the upper part of the tropical Chaetoceros sp. Zone.

\section{Coscinodiscus excentricus Ehrenberg} (Plate 13, Figure 5)

The curved lines of areolae in this species are eccentric with respect to the center of the disc. Stratigraphically, it is a prominent, consistent member of Pleistocene to upper Miocene assemblages in the Panama
Basin. Its first significant occurrence is at the bottom of the tropical Chaetocerossp. Zone. Its appearance after the extinction of Coscinodiscus plicatus matches the stratigraphic relation observed by Kolbe (1954) in the tropical Swedish Deep-Sea Expedition cores.

\section{Coscinodiscus gigas diorama (Schmidt) (Plate 13, Figure 1)}

This is the largest intact species observed in the Panama Basin cores. It is characterized by areolae that are radially alligned and that are largest at the periphery and become progressively smaller toward the center. The general stratigraphic significance of this form was suggested by Kolbe (1954), and its middle Miocene zonal significance was demonstrated by Kanaya (1971). The large size and great abundance of this species in DSDP 158, Cores 31 to 33, are distinctive and aid in recognition of the Craspedodiscus coscinodiscus Zone. The disjunct Pleistocene forms assigned to this taxon have thinner centers and are more convex than the Miocene forms.

\section{Coscinodiscus lewisianus Greville (Plate 13, Figures 6-7)}

Only a single fragment of this species was found in the Panama Basin cores, but Kanaya (1971) indicated that it proved to be particularly common in the lower EM cores, which include the stratigraphic section just below that in which DSDP 158 terminated. This suggests that it may prove useful in subdividing the Craspedodiscus coscinodiscus Zone.

\section{Coscinodiscus lineatus Ehrenberg \\ (Plate 13, Figures 2-5)}

The alignment of the equant areolae into straight parallel rows and the typically broad margin characterize this circular species. The occurrence of spikes in the margin area is common. Distinctly elliptic forms of the species occur only in Pleistocene cores from the Panama Basin. This is one of the few long-ranging species that occurs in virtually every core examined.

\section{Coscinodiscus marginatus Ehrenberg \\ (Plate 13, Figure 8)}

This small robust species is considered to be representative of boreal to warm-temperate waters (Kanaya and Koizumi, 1966; Lohman, 1941). In the Panama Basin, its typical range is in the Miocene Craspedodiscus coscinodiscus Zone and the Coscinodiscus plicatus Zone. A few sporadic occurrences are noted higher in the section.

\section{Coscinodiscus nodulifer Schmidt (Plate 13, Figure 9)}

As noted by Kolbe (1954), this distinctive warm-water diatom is exceedingly abundant in Pleistocene sediment from the equatorial $\mathrm{Pa}$ cific. For combined range and abundance, it is the preeminent species at our Panama Basin sites in the upper Miocene to Pleistocene. Its first common occurrence is noted within the nannofossil Discoaster quinqueramus Zone at both DSDP 157 (Core 37) and DSDP 158 (Core 17). The central nodule and intersecting spiral patterns of areolae are useful identification keys. Kolbe (1954) pointed out that the dominance of this form as fossils and its relatively low abundance in the living plankton indicate that it is more resistant to dissolution than other species.

\section{Coscinodiscus paleaceus Grunow}

(Plate 13, Figure 10)

This small, narrowly lanceolate species has diagonally aligned areolae. It is a characteristic species in the nannofossil Discoaster exilis Zone in tropical Pacific cores from both DSDP Leg 8 and DSDP Leg 16. Its total range at Site DSDP 158 closely matches that of Coscinodiscus plicatus. These occurrences support Kanaya's (1971) work indicating that $C$. paleaceus is an important guide species for tropical Miocene assemblages.

\section{Coscinodiscus plicatus Grunow (Plate 13, Figure 11)}

This species has radially aligned areolae and a single raised plication along one diameter. In typical orientation on strewn slides, only one side of the disk at a time can be focused. In the Panama Basin, this form ranges only from the middle Miocene to the lower upper Miocene. Kanaya (1971) has discussed the taxonomy and stratigraphy of this species. The Panama specimens tend to have finer areolae than those illustrated by Kanaya from the EM cores. 
Coscinodiscus vetutissimus Pantocsek (Plate 14, Figure 1)

As illustrated in Kanaya (1971), this species is characterized by equant, radially aligned areolae. It is not present above the upper Miocene at DSDP 158, which confirms the earlier disappearance of this species in the tropical Pacific than in northern areas (Kanaya and Koizumi, 1970).

\section{Craspedodiscus coscinodiscus Ehrenberg} (Plate 14, Figure 3)

This unusual circular species is easily identified by its distinctive inflated central area and by the small size of the central area areolae. The areolae in the brim-like part of the disk are distinctly larger. The upper natural range of Craspedodiscus coscinodiscus at DSDP 158 is within the nannofossil Discoaster exilis Zone; this is comparable to the EM section, where it ranges through the $D$. exilis Zone into the adjacent Catinaste coalitus Zone (Kanaya, 1971; Bukry, unpublished data).

\section{Denticula hustedtii Simonsen and Kanaya (Plate 14, Figures 4-5)}

This small elongate diatom has been well characterized stratigraphically and taxonomically by Simonsen and Kanaya (1961), Kanaya and Koizumi (1970), and Kanaya (1971). Determining the full stratigraphic range of this form requires examination of fine and coarse fractions (H.J. Schrader, personal communication, 1971). In the present study of coarse fractions, its range is, nevertheless, comparable to that indicated by Kanaya and Koizumi from the tropical Pacific. A spot check of coeval horizons of the Monterey Formation at Newport Beach, California, shows this and other species of Denticula to be much more abun dant than at DSDP 158

\section{Denticula lauta Bailey}

(Plate 14, Figure 6)

This species is smaller than Denticula hustedtii but has essentially the same middle Miocene to lower upper Miocene stratigraphic range at DSDP 158.

\section{Ethmodiscus rex (Rattray)}

(Plate 14, Figure 7)

This large, finely areolate species is represented only as fragments in the samples examined, but it is a consistent and usually common member of our middle Miocene to Pleistocene sections. It has been classified as a typical tropical form by Lohman (1941) and Kanaya and Koizumi (1966). Resistance of this form to dissolution has been suggested by its occurrence in H.M.S. Challenger samples from depths of 8185 meters and 10,505 meters (Wiseman and Hendey, 1953).

\section{Fragilariopsis pliocena Brun (Plate 14, Figures 8-10)}

As tabulated here, this species includes both the long forms illustrated by Kanaya (1971) and the short forms called Nitzschia praemarine by Muhina (1969). Both the long and short forms are similarly constructed and are most common in the same interval-lower Pliocene to upper Miocene, DSDP 157 (Cores 23 to 35 ). The stratigraphic relations of the whole group are currently being worked out by H.J. Schrader (personal communication, 1972).

\section{Hemidiscus cuneiformis Wallich (Plate 14, Figures 11-12)}

This species is semicircular in plan view and wedge-shaped in side view. It is considered a typical member of tropical assemblages (Kanaya and Koizumi, 1966) but does occur rarely in samples from as far north as Japan (Koizumi, 1968; Jousé et al., 1971). The variable form and size of tropical assemblages of $H$. cuneiformis described by Kolbe (1954) are apparent in the Panama Basin cores. Some variants are stratigraphically restricted-for instance, large angular forms of the Miocene at DSDP 158. The distinctive outline of this species and its variants allows identification by girdle bands alone in poorly preserved samples. The total stratigraphic range of $H$. cuneiformis in our cores is from the middle Miocene upper Craspedodiscus coscinodiscus Zone through the Pleistocene, although it first becomes prominent only at the top of the upper Miocene Coscinodiscus plicatus Zone.

\section{Liostephania sp. \\ (Plate 15, Figure 1 )}

As illustrated and discussed by Kolbe (1954), the exact nature of these silicified disks is uncertain. The single specimen observed in our samples is reminiscent of Asteromphalus, with slits occurring where hyaline rays would have been originally. Whether this is a biologically controlled structure or a preservation artifact is unknown.

\section{Nitzschia marina Grunow \\ (Plate 15, Figure 2)}

This elongate, essentially parallel-sided species is similar in construction to short and long forms of Fragilariopsis pliocena but lacks their distinctly convex sides. Kanaya and Koizumi (1970) indicate a Miocene to Holocene range for $N$. marina. In the Panama Basin cores, it was noted in upper Pliocene and higher samples. Lohman (1941) considered it to be mainly a cool-water species, but it ranges into the tropics and has been classified as tropical by Kanaya and Koizumi (1966).

Pleurosigma sp.

(Plate 15, Figure 3)

These large, thin, elongate, lozenge-shaped diatoms have a straight raphe and oblique and transverse striae (see Cupp, 1943). The rare and sporadic occurrences at DSDP 157 and DSDP 158 range from upper Miocene to Pleistocene.

\section{Pseudoeunotia doliolus (Wallich) (Plate 15, Figure 4)}

This small, elongate, asymmetric species, as illustrated by Kolbe (1954), is a meager to rare component noted mainly in the fine fraction of Pleistocene samples from DSDP 157. Sporadic occurrences in the coarse fraction are noted in and above the upper upper Miocene, although the early forms lack the full character of the species and are transitional from Nitzschia fossilis according to H.J. Schrader (personal communication, 1972). Kanaya and Koizumi (1970) indicate an upper Pliocene first occurrence in the tropics, but a lower Pliocene appearance at higher latitudes. Lohman (1941) considered it a warm-water, littoral species.

\section{Rhizosolenia bergonii Peragallo \\ (Plate 15, Figure 5)}

As noted by Lohman (1941), this tropical species is usually represented in sediment only by apical spines. Owing to the small size of the spines, this species has been noted only rarely in our coarse fractions.

\section{Roperia tesselata (Roper) \\ (Plate 15, Figures 9-11)}

This circular species is characterized by an irregular patchwork quilt appearance of its areolae alignments. It is considered a tropical to subtropical species (Kanaya and Koizumi, 1966) but has also been reported as a characteristic living species in the Central Water Mass of the Pacific (Venrick, 1971), suggesting a broader temperature range. In the Panama Basin it first appears near the base of the Pleistocene and is most common in the upper Pleistocene, which could suggest a general worldwide cooling in the upper Pleistocene (Burckle, 1971).

\section{Stictodiscus sp. cf. S. californicus Greville}

(Plate 16, Figures 1-2)

Included under this taxon are a variety of circular diatoms that are characterized by elevated radial ridges and sparsely punctate central areas. No attempt has been made to separate varieties here because the group is present only in small numbers sporadically throughout the whole section examined. Stictodiscus has been variously considered to be littoral, benthonic, or epiphytic. Kolbe (1954) noted it only in cores near the Islas Galapagos, its occurrence probably representing displacement from shallower areas.

\section{Stictodiscus trigonus Castracane}

(Plate 16, Figures 3-6)

This thick triangular species has been reported from recent dredge samples (Castracane, 1886) and from Miocene outcrops (Reinhold, 1937). In the Panama Basin, virtually identical forms were noted only in Pleistocene and middle Miocene samples. 
Thalassionema nitzschioides (Grunow) s.l. (Plate 16, Figures 7-8)

This elongate species is narrowly rhomboid, and large specimens may be slightly curved. Included in this species is a cooccurring short, noncurved form called Thalassionema parva by Muhina (1969). T. nitzschioides is considered north temperate by Cupp (1943), cool-water by Hendey (1937), and southern boreal by Kanaya and Koizumi (1966). Its occurrence in the Panama Basin cores is primarily in the upper Miocene. It also occurs sporadically in the middle Miocene and Pliocene; in the Pleistocene it is noted only in fine fractions.

\section{Thalassiothrix spp. \\ (Plate 16, Figure 9)}

Included in this category are a variety of long, narrow, parallel-sided forms, which are straight or slightly wavy. The narrowest form, Thalassiothrix longissima Cleve and Grunow, has prominent transverse notches (see Koizumi, 1968). Hendey (1937) considered this taxon to indicate cool water but also noted that the small living space and large amount of skeletal material in such elongate forms suggested inefficient utilization of silica. This suggests that, particularly in equatorial waters of the Panama Basin where these forms are abundant, upwelling providing excess silica and nutrients, not cool temperature, is the determining developmental factor. The associated diatoms there are clearly tropical to subtropical, so Thalassiothrix abundances, at least at the generic level, can be considered a guide to relatively strong upwelling. Thalassiothrix spp. occur from upper Miocene to Pleistocene in the Panama Basin; they are especially abundant in coarse fractions in Miocene and Pleistocene.

\section{Triceratium cinnamomeum Greville}

(Plate 16, Figures 10-11)

These medium to large triangular diatoms have fine, radially aligned areolae and are considered to be typical of tropical assemblages (Kanaya and Koizumi, 1966). Although occurring sporadically throughout the Panama Basin section, $T$. cinnamomeum is most consistently present in the middle Miocene and lower Pliocene.

\section{Triceratium cinnamomeum minor Grunow}

This small somewhat rounded variety of Triceratium is rare in middle Miocene samples at DSDP 158. Kolbe (1954, fig. 20) presented an excellent illustration of this form.

\section{?Triceratium thumii Schmidt}

(Plate 16, Figure 12)

A single specimen of this coarsely areolated, triangular form was observed in the upper Miocene at DSDP 158. Wornardt (1967) illustrated this species from the Miocene Monterey Formation of California.

\section{ACKNOWLEDGMENTS}

We thank George W. Moore and Dorothy L. Blackstock, U. S. Geological Survey, and Ted C. Moore, Jr., Oregon State University, for many suggestions during the preparation of this report. Ann M. Strathern and Michael Lehmann, Deep Sea Drilling Project, provided assistance during preparation of part of the samples aboard the Glomar Challenger. The technique for cleaning samples-sequential treatment by $\mathrm{HCl}, \mathrm{H}_{2} \mathrm{O}_{2}$, Calgon, and wet sieving-was suggested by Menno G. Dinkelman, Oregon State University. Reference samples from the Experimental Mohole were provided by M. N. Bramlette, Scripps Institution of Oceanography; those from the Newport Bay section were made available through the courtesy of A.D. Warren, Mobil Oil Corporation. Daniel L. Gittings, National Marine Fisheries Service, and William Sanders, U.S. Geological Survey, helped to obtain much of the literature referenced. We acknowledge our indebtedness to the authors of the following recent publications that have been especially useful in evaluating taxonomic, biogeographic, and stratigraphic aspects of silicoflagellates and diatoms: Silicoflagellates-Loeblich et al. (1968), Mandra (1968), Ling (1970), Lipps (1970), Jousé (1971), and Martini (1971); Diatoms-Kanaya and Koizumi (1966; 1970), Koizumi (1968), Muhina (1969), Donahue (1970), Kanaya (1971), Schrader (1971), and Tappan (1971).

\section{REFERENCES}

Arrhenius, G., 1952. Geology of the east equatorial Pacific. Rept. Swedish Deep-Sea Exped. 5, 189.

Bachmann, A., 1970. Silicoflagellaten aus dem oberösterreichischen Egerien (Oberoligozän). Geol. Bundesanst. Verh. 2. 275

Burckle, L.H., 1969. Late Cenozoic planktonic diatom zones in equatorial Pacific sediment cores. Geol. Soc. Am. Abstracts with Programs. 1 (7), 24.

1971. Late Pleistocene diatom assemblages from the Eastern Equatorial Pacific. Geol. Soc. Am. Abstracts with Programs. 3, 518.

Castracane, F., 1886. Report on the Diatomaceae collected by H.M.S. Challenger during the years 1873-76. Challenger Rept., Botany. 2, 1.

Cupp, E.E., 1943. Marine plankton diatoms of the west coast of North America. Bull. Scripps Inst. Oceanogr., Tech. Ser. 5, 1.

Desikachary, T.V. and Maheshwari, C.L., 1956. Fossil silicoflagellates from Colebrook and Nancoori Islands. J. Indian Bot. Soc. 35, 257.

Donahue, J.G., 1970. Pleistocene diatoms as climatic indicators in North Pacific sediments. Geol. Soc. Am. Mem. 126, 121.

Frenguelli, J., 1940. Consideraciones sobre los sílicoflagelados fósiles. Mus. La Plata Rev., Paleontol. 7, 37. 1951. Silicoflagelados del Tripoli de Mejillones (Chile). Physis [Buenos Aires]. 20, 272.

Gemeinhardt, K., 1930. Silicoflagellatae. In Rabenhorst, L. (Ed.), Kryptogamem-Flora von Deutschland, Osterreich und der Schweiz. Akad. Verlagsgesell. 10, 1.

1934. Die Silicoflagellaten des südatlantischen Ozeans. Wiss. Ergeb. deutschen Atlantischen Exped. "Meteor", 1925-1927. 12, 274.

Hanna, G.D., 1932. The diatoms of Sharktooth Hill, Kern County, California. California Acad. Sci. Proc. 20, 161.

Hays, J.D., Saito, T., Opdyke, N.D. and Burckle, L.H., 1969. Pliocene-Pleistocene sediments of the equatorial Pacific: Their paleomagnetic, biostratigraphic, and climatic record. Bull. Geol. Soc. Am. 80, 1481.

Hendey, N.I., 1937. The plankton diatoms of the southern seas. Discovery Repts. 16, 151.

1964. An introductory account of the smaller algae of British coastal waters, Part V: Bacillariophyceae (diatoms). London (Her Majesty's Stationery Office). 1.

Ichikawa, W., Fugi, N. and Bachmann, A., 1967. Fossil silicoflagellates and their associated uncertain forms in Iida Diatomite, Noto Peninsula, Central Japan. Kanazawa Univ. Sci. Repts. 12, 143.

Jousé, A.P., 1969. Diatomei v osadkakh Pleistotsenovogo i pozdnepliotsenovogo vozrasta borealnoi oblasti Tihovo Okeana [Diatoms in the sediments of Pleistocene and late Pliocene of the boreal zone of the Pacific Ocean]. In Jousé, A.P., (Ed.), Micropaleontology and Organogenous Sedimentation in the Oceans. "Nauka" Publishing Office. 5.

1971. Diatoms in Pleistocene sediments from the northern Pacific Ocean. In Funnell, B.M. and Riedel, W.R., (Eds.), The Micropaleontology of Oceans. Cambridge (Cambridge Univ. Press). 407.

Jousé, A.P., Kozlova, O.G. and Muhina, V.V., 1971. Distribution of diatoms in the surface layer of sediment from the Pacific Ocean. In Funnell, B.M. and Riedel, W.R., (Eds.), The Micropaleontology of Oceans. Cambridge (Cambridge Univ. Press). 263.

Kamatani, A., 1971. Physical and chemical characteristics of biogenous silica. Marine Biol. 8, 89 . 
Kanaya, T., 1971. Some aspects of pre-Quaternary diatoms in the oceans. In Funnell, B.M. and Riedel, W.R., (Eds.), The Micropaleontology of Oceans. Cambridge (Cambridge Univ. Press). 545.

Kanaya, T. and Koizumi, I., 1966. Interpretation of diatom thanatocoenoses from the North Pacific applied to a study of core V20-130. Tohoku Univ. Sci. Repts. 37, 89.

1970. The progress in the younger Cenozoic diatom biostratigraphy in the northern Circum-Pacific region [in Japanese]. J. Marine Geol. 6, 47.

Koizumi, I., 1968. Tertiary diatom flora of Oga Peninsula, Akita Prefecture, northeast Japan. Tohoku Univ. Sci. Repts.40, 171.

Kolbe, R.W., 1954. Diatoms from equatorial Pacific cores. Repts. Swedish Deep-Sea Exped. 6 (1), 1.

Lemmermann, E., 1901. Silicoflagellatae. Deutsche Bot. Gesell. 19, 247.

Ling, H-Y., 1970. Silicoflagellates from central North Pacific core sediments. Bull. Am. Paleontol. 58, 85.

1971. Silicoflagellates and ebridians from the Shinzan Diatomaceous Mudstone Member of the Onnagawa Formation (Miocene), northeast Japan. Proc. Second Plankt. Conf. 689.

Lipps, J.H., 1970. Ecology and evolution of silicoflagellates. North American Paleontol. Conv. Proc. Pt. G. 965.

Loeblich, A.R., III, Loeblich, L.A., Tappan, H. and Loeblich, A.R., Jr., 1968. Annoted index of fossil and recent silicoflagellates and ebridians with descriptions and illustrations of validly proposed taxa. Geol. Soc. Am. Mem. 109, 1 .

Lohman, K.E., 1941. Geology and biology of North Atlantic deep-sea cores between Newfoundland and Ireland. Pt. 3. Diatomaceae. U. S. Geol. Survey Prof. Paper. 196-B, 55.

Mandra, Y.T., 1968. Silicoflagellates from the Cretaceous, Eocene, and Miocene of California, U.S.A. California Acad. Sci. Proc. 36, 231.

1969. Silicoflagellates: A new tool for the study of Antarctic Tertiary climates. Antarctic J. U.S. 4, 172.

Martini, E., 1971. Neogene silicoflagellates from the equatorial Pacific. In Winterer, E.L., Riedel, W.R. et al., 1971. Initial Reports of the Deep Sea Drilling Project, Volume 7. 1695.

McGowan, J.A., 1971. Oceanic biogeography of the Pacific. In Funnell, B.M. and Riedel, W.R., (Eds.), The Micropaleontology of Oceans. Cambridge (Cambridge Univ. Press). 3.

Muhina, V.V., 1969. Biostratigrafiya osadkov i nekotorye voprocy paleogeografii tropicheskoi oblasti Tihovo i Indiiskovo Okeanov [Biostratigraphy of sediments and some questions of paleogeography of the tropical region of the Pacific and Indian Oceans]. In Jousé, A.P., (Ed.), Micropaleontology and Organogenous Sedimentation in the Oceans. "Nauka" Publishing Office. 52.

1971. Problems of diatom and silicoflagellate Quaternary stratigraphy in equatorial Pacific Ocean. In Funnell, B.M. and Riedel, W.R., (Eds.), The Micropaleontology of Oceans. Cambridge (Cambridge Univ. Press). 423.

Namias, J., 1969. Seasonal interactions between the North Pacific Ocean and the atmosphere during the 1960's. Monthly Weather Rev. 97, 173.

Nayudu, Y.R., 1964. Carbonate deposits and paleoclimatic implications in the northeast Pacific Ocean. Science. 146, 515.

Reinhold, T., 1937. Fossil diatoms of the Neogene of Java and their zonal distribution. Nederland en Kolonien Geol. Mijnbouwk Genootschap Verh., Geol. Ser. 12, 43.

Schrader, H-J., 1971. Fecal pellets: Role in sedimentation of pelagic diatoms. Science. 174, 55.

Schulz, P., 1928. Beiträge zur Kenntnis fossiler und rezenter Silicoflagellaten. Bot. Archiv. 21, 225.

Simonsen, R. and Kanaya, T., 1961. Notes on the marine species of the diatom Genus Denticula Kutz. Internat. Rev. ges. Hydrobiol. 46, 498.

Tappan, H., 1971. Microplankton, ecological succession and evolution. North American Paleontol. Conv. Proc. Pt. H. 1058.

Tsumura, K., 1963. A systematic study of Silicoflagellatae. Yokohama Municipal Univ. J. C-45, 1.

van Hinte, J. E., 1969. The nature of biostratigraphic zones. Proc. First. Internat. Conf. Plankt. Microfossils. 2, 267.

Van Valkenburg, S. D. and Norris, R. E., 1970. The growth and morphology of the silicoflagellate Dictyocha fibula Ehrenberg in culture. J. Phy cology. 6, 48.

Venrick, E. L., 1971. Recurrent groups of diatom species in the North Pacific. Ecology. 52614.

Wilcoxon, J. A., 1969. Tropical planktonic zones and calcareous nannoplankton correlations in part of the California Miocene. Nature. 221, 950.

Wiseman, J. D. H. and Hendey, N. I., 1953. The significance and diatom content of a deep-sea floor sample from the neighbourhood of the greatest oceanic depth. Deep-Sea Res. 1, 47.

Wornardt, W. W., 1967. Miocene and Pliocene marine diatoms from California. California Acad. Sci. Occasional Paper. 631. 
PLATE 1

Silicoflagellate Photomicrographs: $600 \times$

Figures 1-2 Cannopilus binoculus (Ehrenberg)

1. DSDP 157-23(CC).

2. DSDP $157-25(C C)$.

Figure 3 Cannopilus hemisphaericus (Ehrenberg) DSDP 157-21(CC).

Figures 4-7 Cannopilus major (Frenguelli)
4. DSDP 157-21(CC).
5. DSDP 157-26(CC).
6. DSDP 157-21(CC).
7. DSDP $157-21(C C)$.

Figures 8-9 Cannopilus quintus Bukry and Foster, n. sp. DSDP 157-22(CC), Holotype USNM 182794.

8. High focus.

9. Low focus. 
PLATE 1
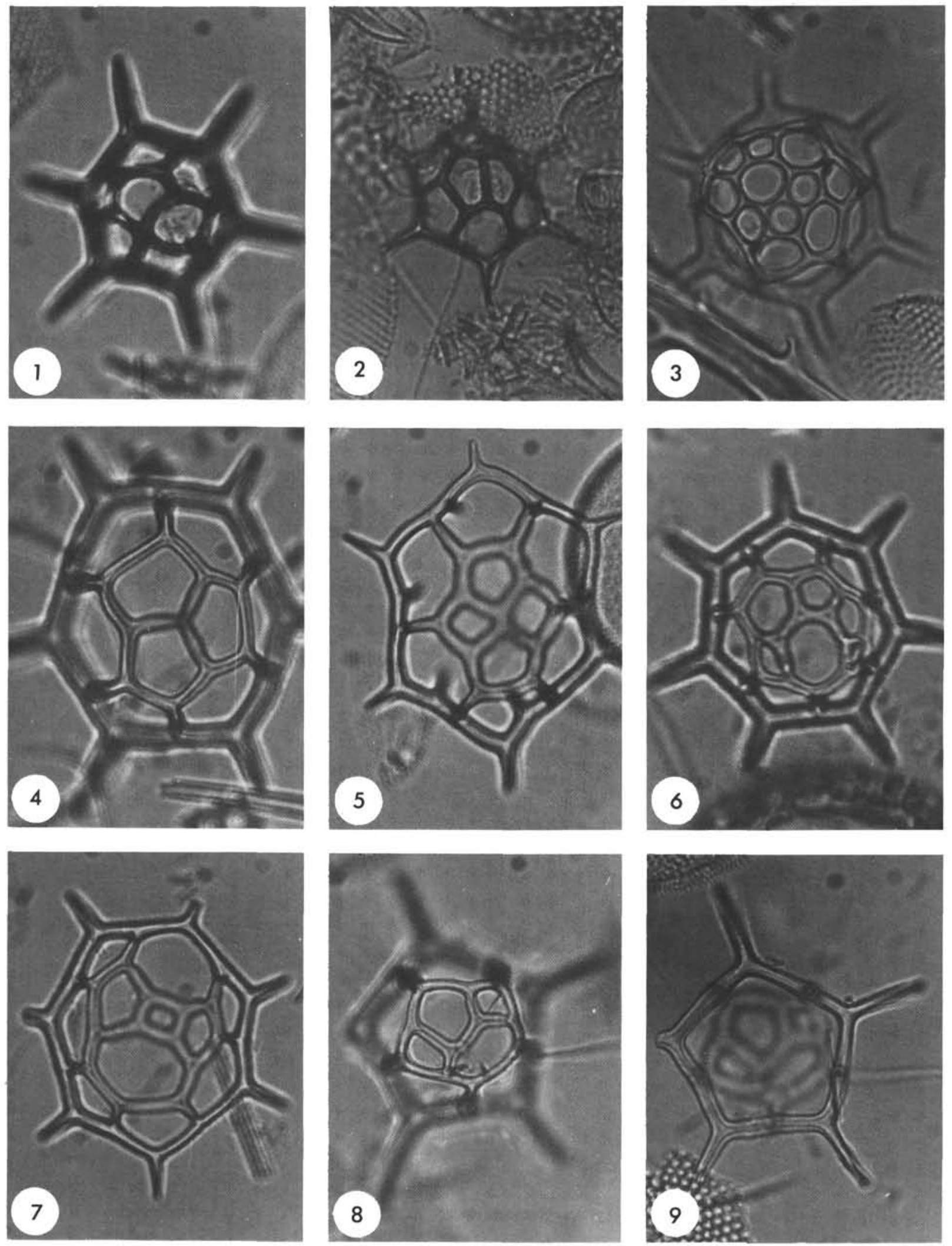


\section{PLATE 2}

Silicoflagellate Photomicrographs: $600 \times$

Figure 1

Figure 2

Figure 3

Figures 4-6
Cannopilus quintus Bukry and Foster, n. sp. DSDP 157-22(CC), Paratype USNM 182795.

Cannopilus schulzii Deflandre DSDP 157-24(CC).

Corbisema triacantha (Ehrenberg) EM 8-15, 34-37 cm.

Dictyocha aspera (Lemmermann)

4. DSDP 157-8(CC).

5. DSDP 158-12(CC).

6. DSDP 158-32(CC).

Figures 7-8 Dictyocha epiodon Ehrenberg

7. DSDP $157 \mathrm{~A}-1 \mathrm{~A}-2(8-10 \mathrm{~cm})$.

8. DSDP $157 \mathrm{~A}-1 \mathrm{~A}-2(8-10 \mathrm{~cm})$.

Figure 9 Dictyocha fibula Ehrenberg DSDP 157-18(CC). 
PLATE 2
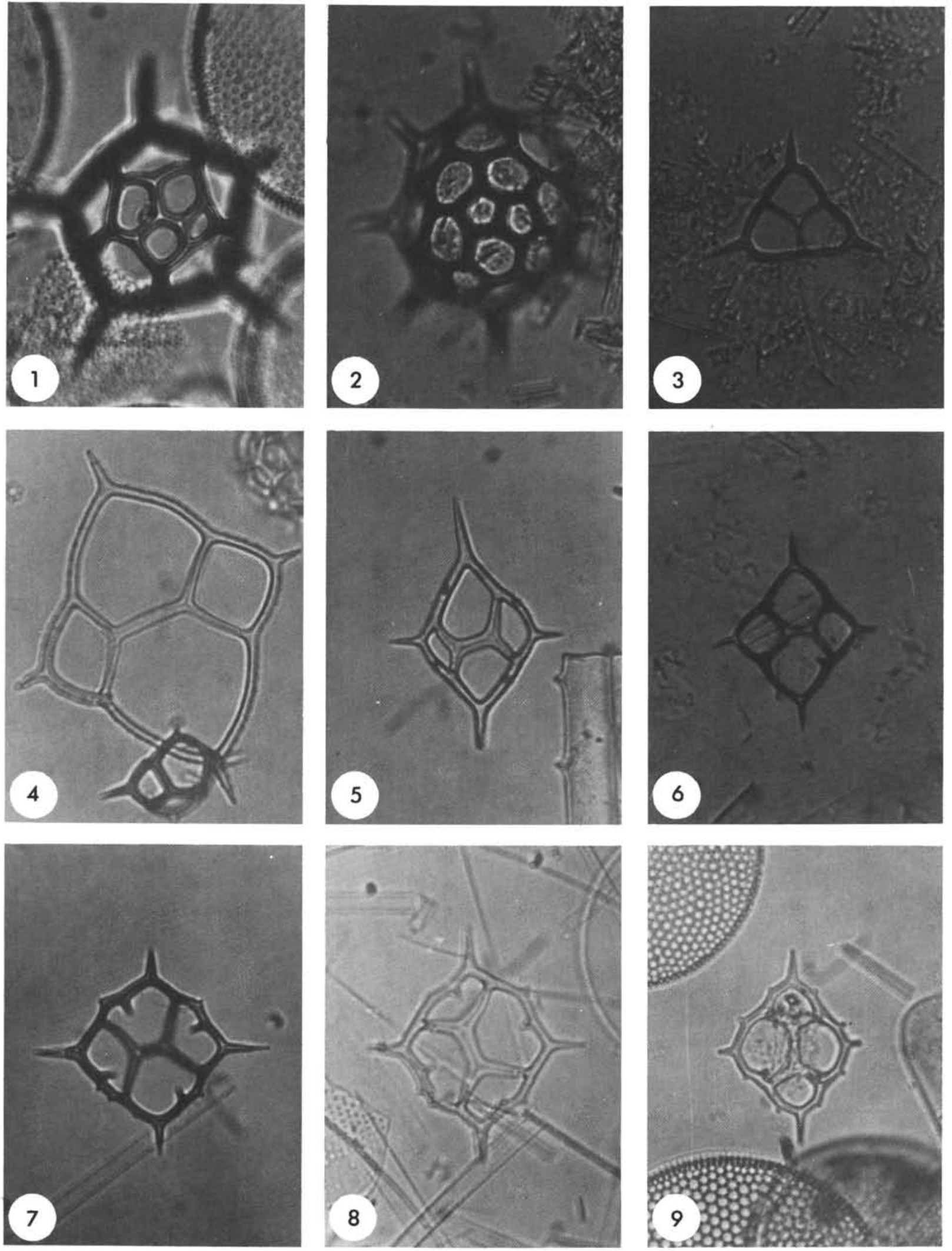
PLATE 3

Silicoflagellate Photomicrographs: $600 \times$ Except Figure 3 Which Is $1200 \times$

Figures 1, 12

Dictyocha fibula Ehrenberg

1. DSDP 157-3(CC).

12. Dsdp 157-23(CC).

Figure 3 Dictyocha japonica Deflandre DSDP 157-37(CC).

Figures 4-5 Dictyocha medusa Haeckle

4. DSDP 158-20(CC).

5. DSDP 158-19(CC).

Figures 6-8 Dictyocha navicula Ehrenberg

6. DSDP 157-38(CC).

7. DSDP $157-38(\mathrm{CC})$.

8. DSDP 158-11(CC).

Figure 9 Dictyocha octagona Tsumura EM 7-1, 36-38 cm.

Figure 10 Dictyocha pentagona (Schulz) DSDP 157A-1A(CC).

Figures 2, 11

Dictyocha pseudofibula (Schulz)

2. DSDP 157-19(CC).

11. DSDP 157-32(CC). 
PLATE 3
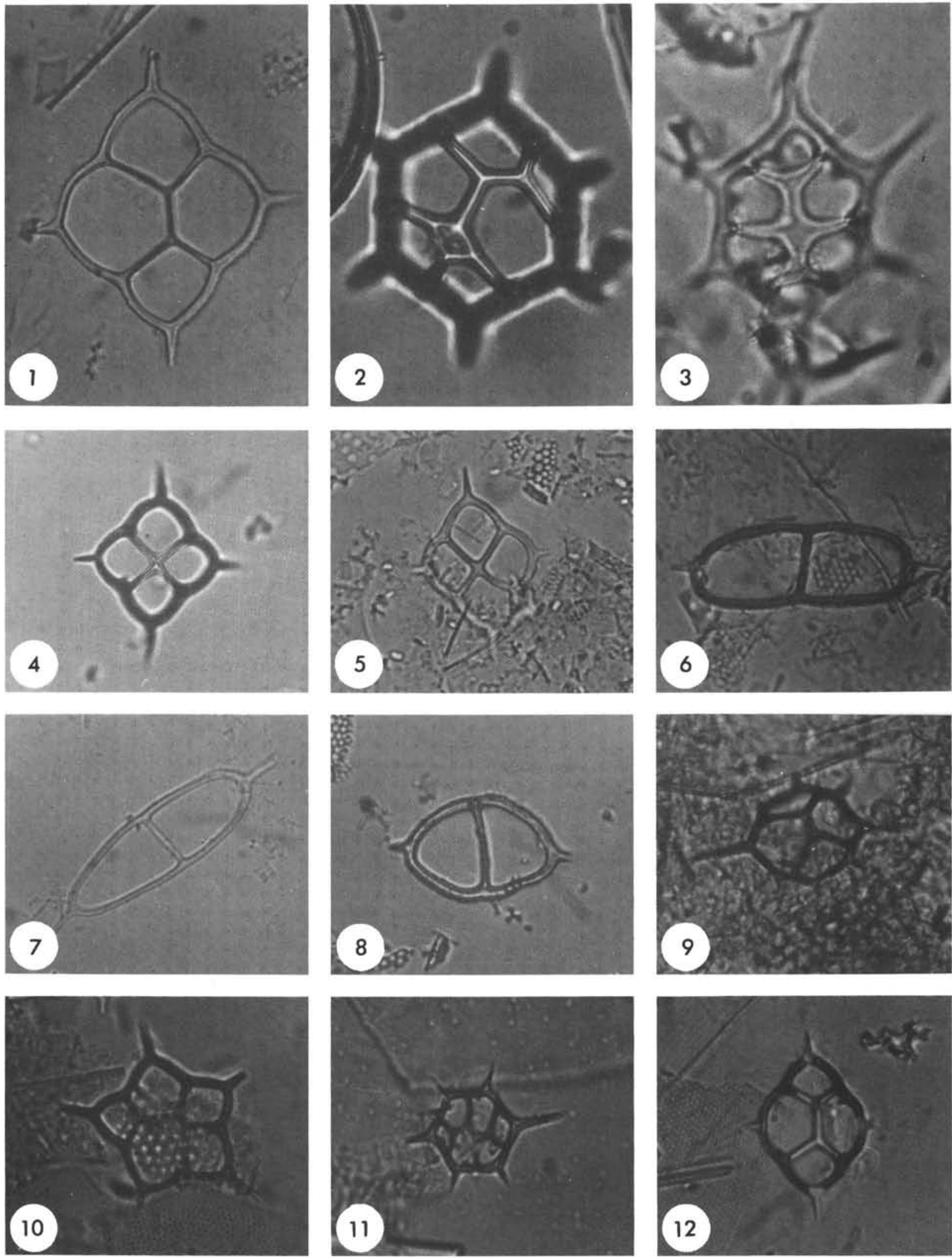


\section{PLATE 4}

Silicoflagellate Photomicrographs: $600 \times$

Figures 1-3 Distephanus boliviensis (Frenguelli)

1. DSDP $157-30(C C)$.

2. DSDP $157-11(\mathrm{CC})$.

3. DSDP 157-32(CC).

Figure 4 Distephanus sp. cf. D. boliviensis (Frenguelli) DSDP 157-36(CC).

Figures 5-6 Distephanus crux (Ehrenberg)

5. DSDP 157A-3A(CC), rim mimics D. epiodon.

6. DSDP 158-31(CC).

Figures 7-8 Distephanus longispinus (Schulz)

7. EM 8-14, 384-387 cm.

8. EM 8-14, 384-387 cm.

Figure 9 Distephanus sp. cf. D. longispinus (Schulz) DSDP 158-31(CC).

Figures 10-11 Distephanus minutus (Bachmann)

10. DSDP $158-16(C C)$.

11. DSDP 157-38(CC).

Figure 12 Distephanus octacanthus (Desikachary and Maheshwari)

EM 7-1, 36-38 cm. 
PLATE 4
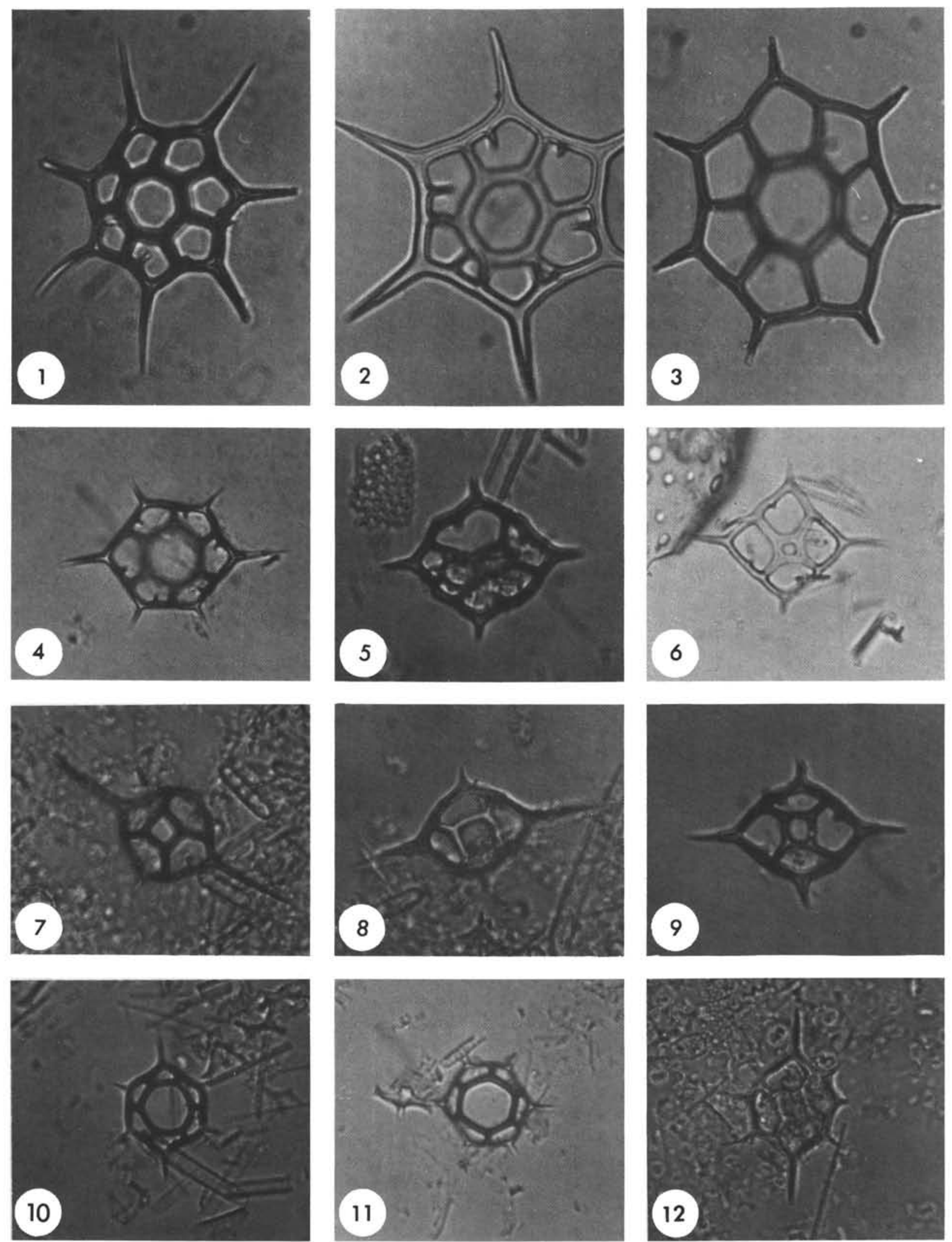


\section{PLATE 5}

Silicoflagellate Photomicrographs: $600 \times$ Except Figure 3 Which Is $1200 \times$

Figure 1 Distephanus octacanthus (Desikachary and Maheshwari)

EM 7-1, 36-38, cm.

Figures 2-3 Distephanus parvus (Bachmann)

2. DSDP $157-38(C C)$.

3. same, $1200 \times$.

Figure 4 Distephanus quinquangellus Bukry and Foster, nomen novum DSDP 157-3(CC).

Figure 5 Distephanus sp. cf. D. quinquangellus Bukry and Foster

EM 8-12, 25-27 cm.

Figures 6-7 Distephanus polyactis (Ehrenberg)

6. DSDP 157-27(CC).

7. DSDP 157-30(CC).

Figure $8 \quad$ Distephanus speculum (Ehrenberg) DSDP 158-15(CC).

Figure 9 Mesocena circula (Ehrenberg) DSDP 157-17(CC). 


\section{PLATE 5}
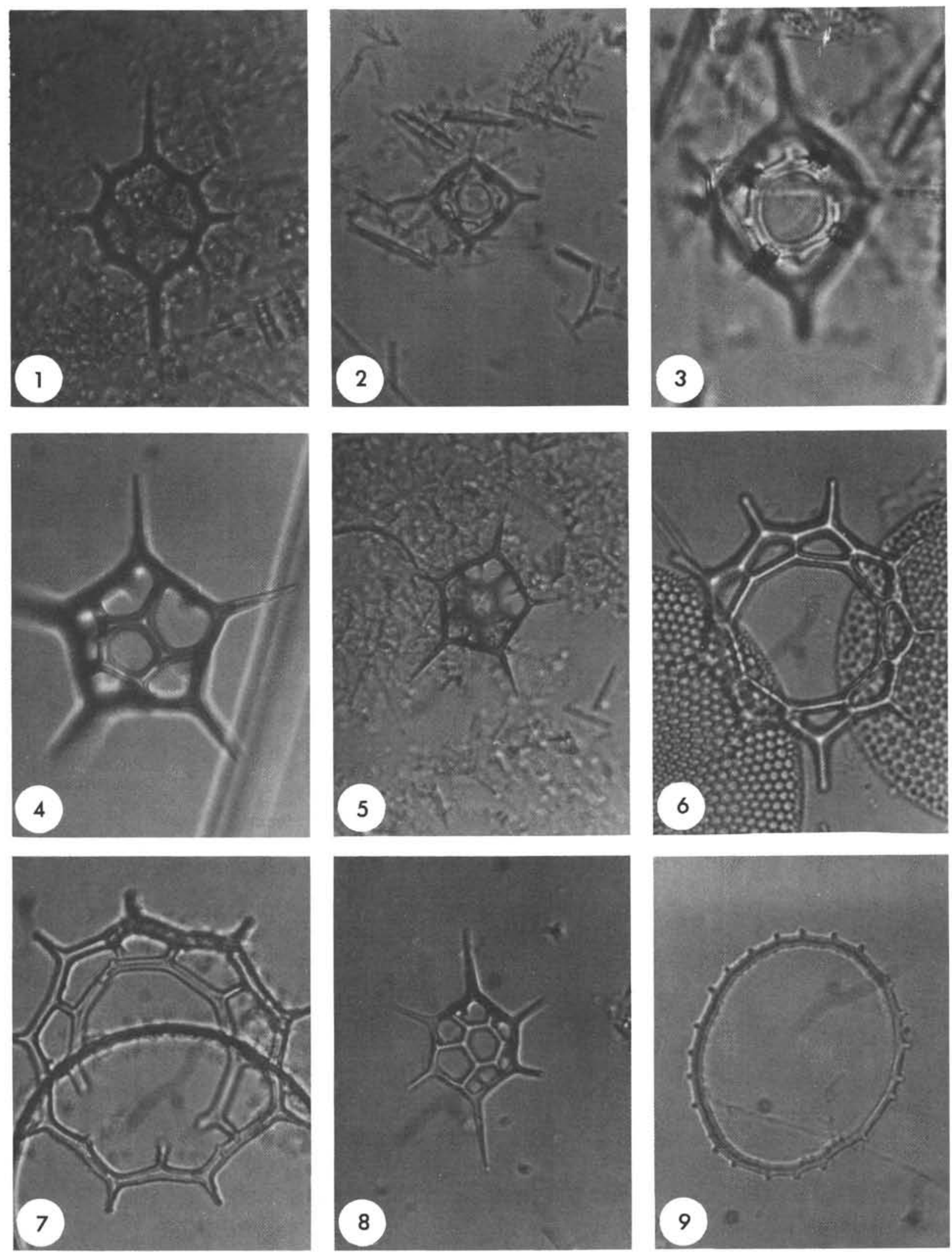


\section{PLATE 6}

Silicoflagellate Photomicrographs: $600 \times$

Figure $1 \quad$ Mesocena circula (Ehrenberg)

DSDP 158-20(CC).

Figures 2-4 Mesocena elliptica (Ehrenberg)

2. DSDP 157-3(CC).

3. DSDP $157-38(C C)$.

4. DSDP $157-7(C C)$.

Figure $5 \quad$ Mesocena-like Dictyocha fibula Ehrenberg DSDP 157-35(CC).

Figures 6-7 Mesocena diodon Ehrenberg

6. DSDP 158-28(CC).

7. DSDP 158-20(CC).

Figure $8 \quad$ Mesocena pentagona Haeckle DSDP $157-6(C C)$

Figures 9-10 Mesocena triangula (Ehrenberg)

9. DSDP 157-14(CC).

10. DSDP 158-14(CC).

Figures 11-12 Octactis pulchra Schiller

11. DSDP 157A-2A(CC).

12. DSDP $157-8(C C)$. 


\section{PLATE 6}
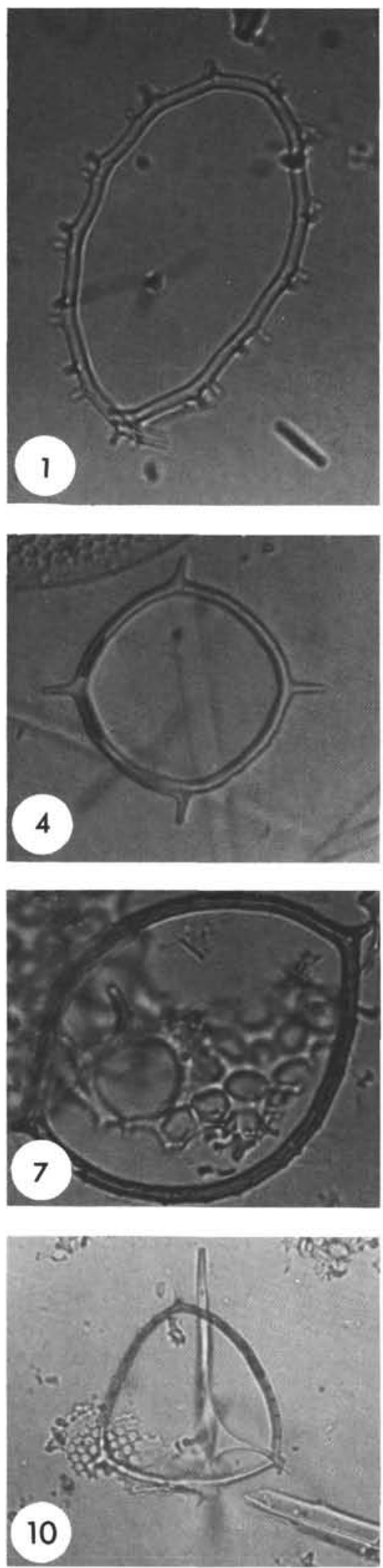
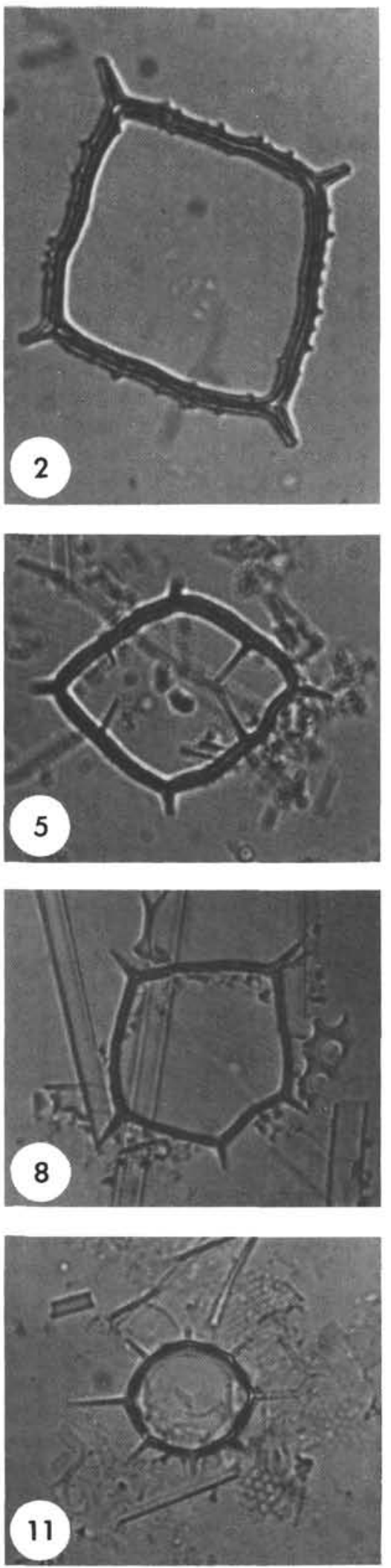
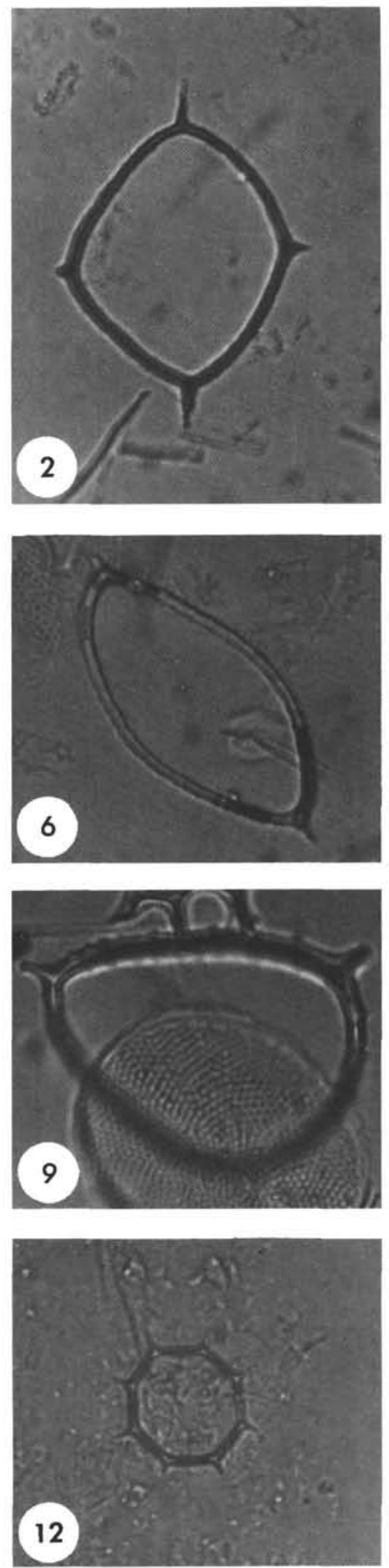
PLATE 7

Silicoflagellate Photomicrographs: $600 \times$

Figure 1 Dictyocha vanandelii Bukry and Foster, n. sp.

DSDP 157-22(CC). Holotype USNM 182796.

Figures 2-4 Juxtaposed skeletons of two taxa

DSDP 157-14(CC).

2. High focus, Cannopilus major (Frenguelli).

3. Mid focus, both basal rings.

4. Low focus, Distephanus boliviensis (Frenguelli). 
Plate 7
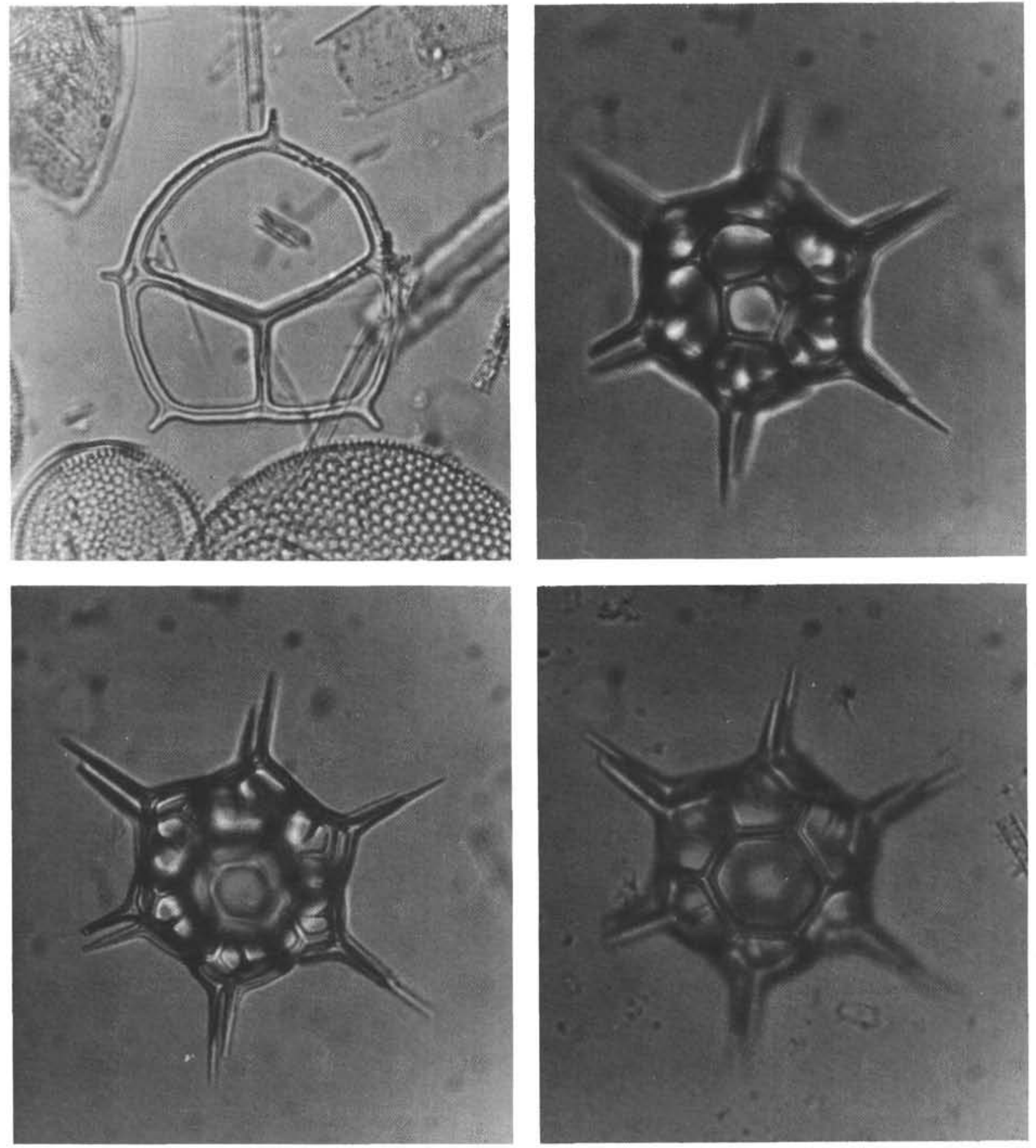
PLATE 8

Diatom Photomicrographs

Figures 1-2 Actinocyclus ehrenbergii Ralfs

1. DSDP $157-30(C C), 600 \times$.

2. DSDP $157-18(C C), 300 \times$.

Figure 3 Actinocyclus ellipticus Grunow DSDP 158-32-CC, $600 \times$.

Figure 4 Actinocyclus ingens Rattray DSDP $158-29(C C), 600 \times$.

Figure $5 \quad$ Actinocyclus sp.

DSDP 158-19(CC), $600 \times$.

Figure $6 \quad$ Arachnoidiscus ornatus Ehrenberg DSDP 158-32(CC), $300 \times$.

Figures 7-9 Actinoptychus senarius Ehrenberg

7. DSDP $157-16(C C), 300 \times$.

8. DSDP 157-16(CC), $600 \times$, tilted.

9. DSDP 158-13(CC), $600 \times$.

Figure 10 Actinoptychus $\mathrm{sp}$. cf. A. vulgaris monicae Grunow DSDP 157A-1A-2, 8-10 cm, $600 \times$.

Figure $11 \quad$ Actinoptychus sp. [8-section] DSDP 158-30(CC). 
PLATE 8
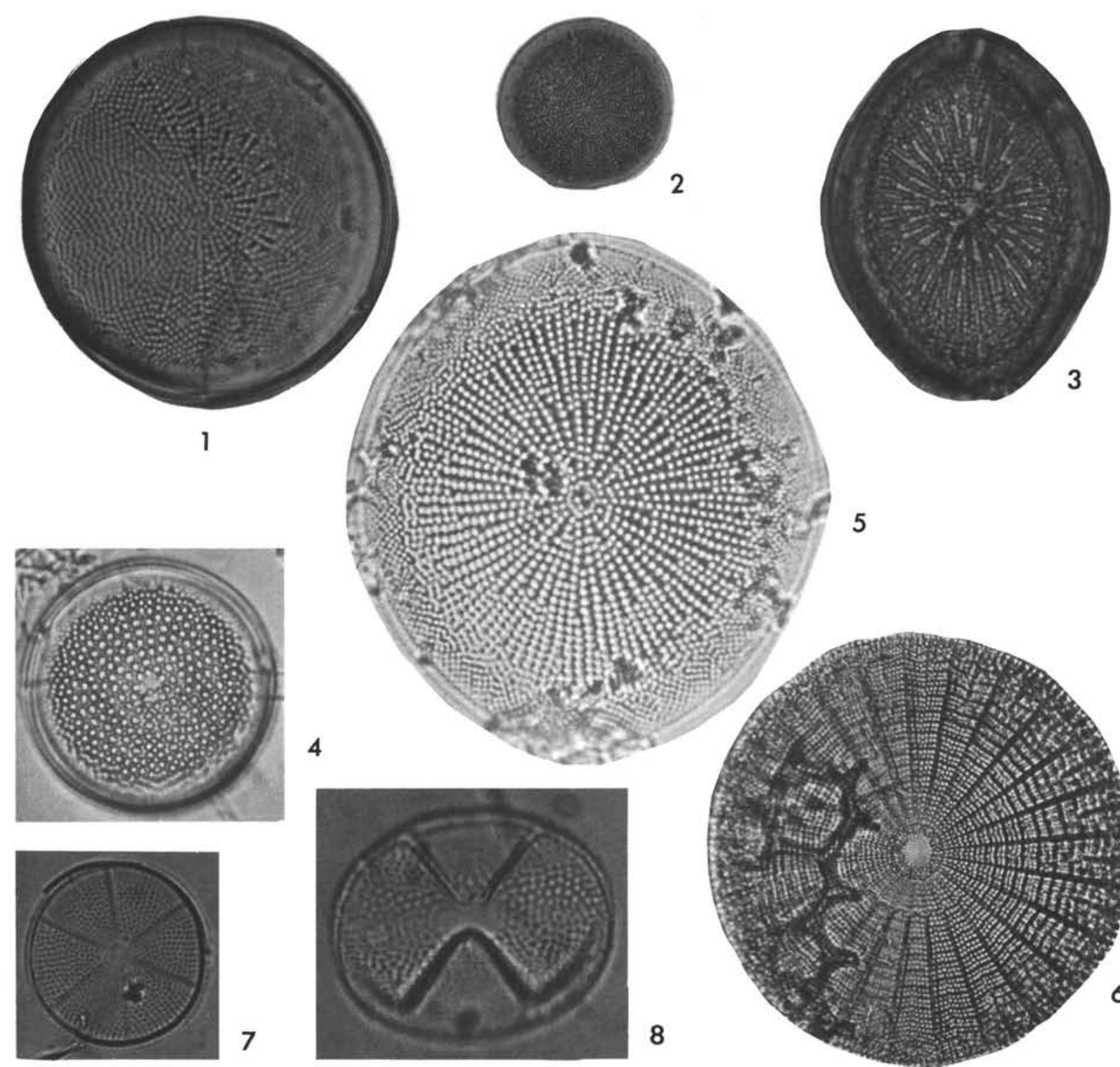

7
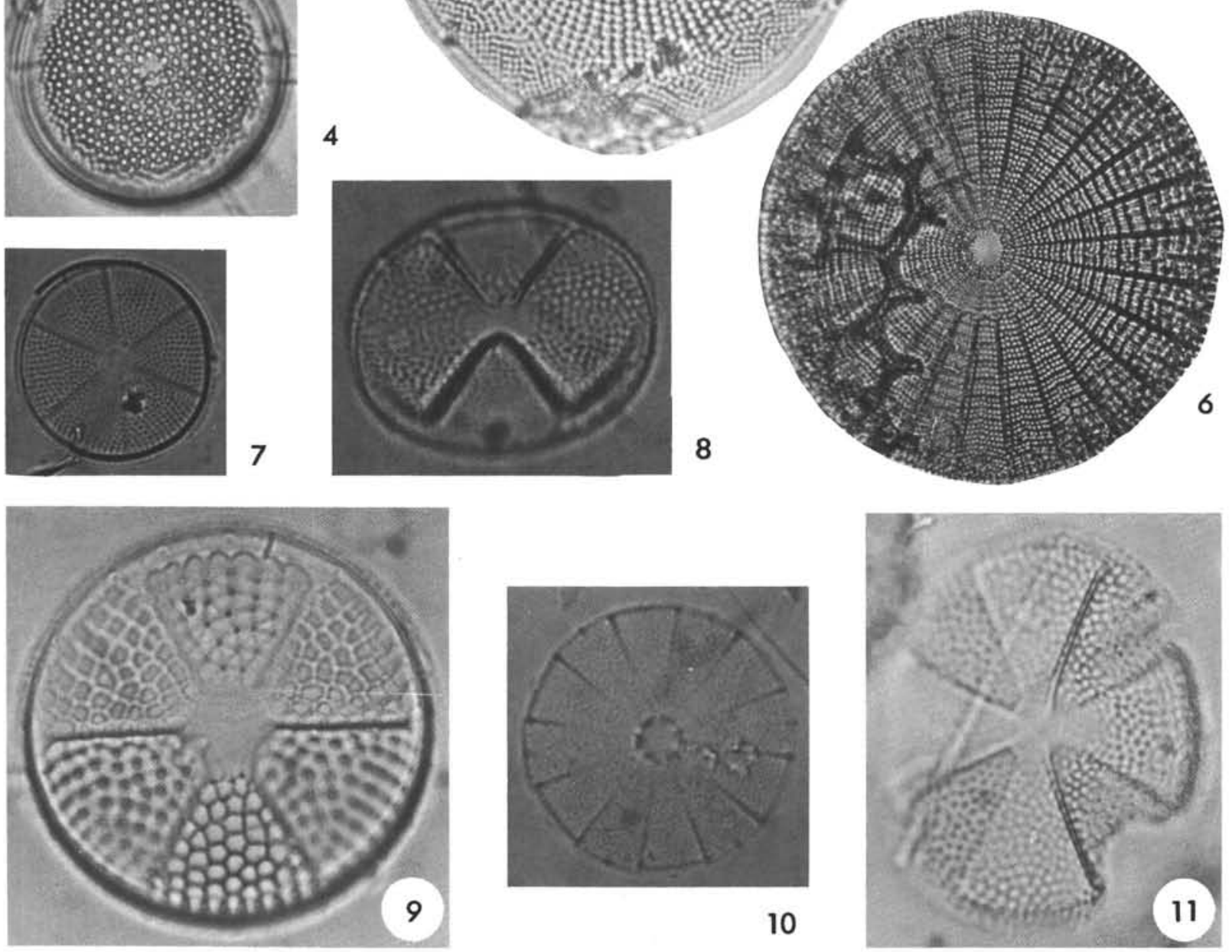
PLATE 9

Diatom Photomicrographs: $600 \times$

Figures 1-2 Actinoptychus sp.

1. DSDP 158-31(CC), high focus.

2. Same, low focus.

Figures 3-4 Asterolampra marylandica Ehrenberg

3. DSDP 158-30(CC).

4. DSDP 158-30(CC).

Figure $5 \quad$ Asterolampra sp. [6-section] DSDP 157-8(CC).

Figure $6 \quad$ Asterolampra sp. [7-section] DSDP 158-19(CC). 


\section{PLATE 9}
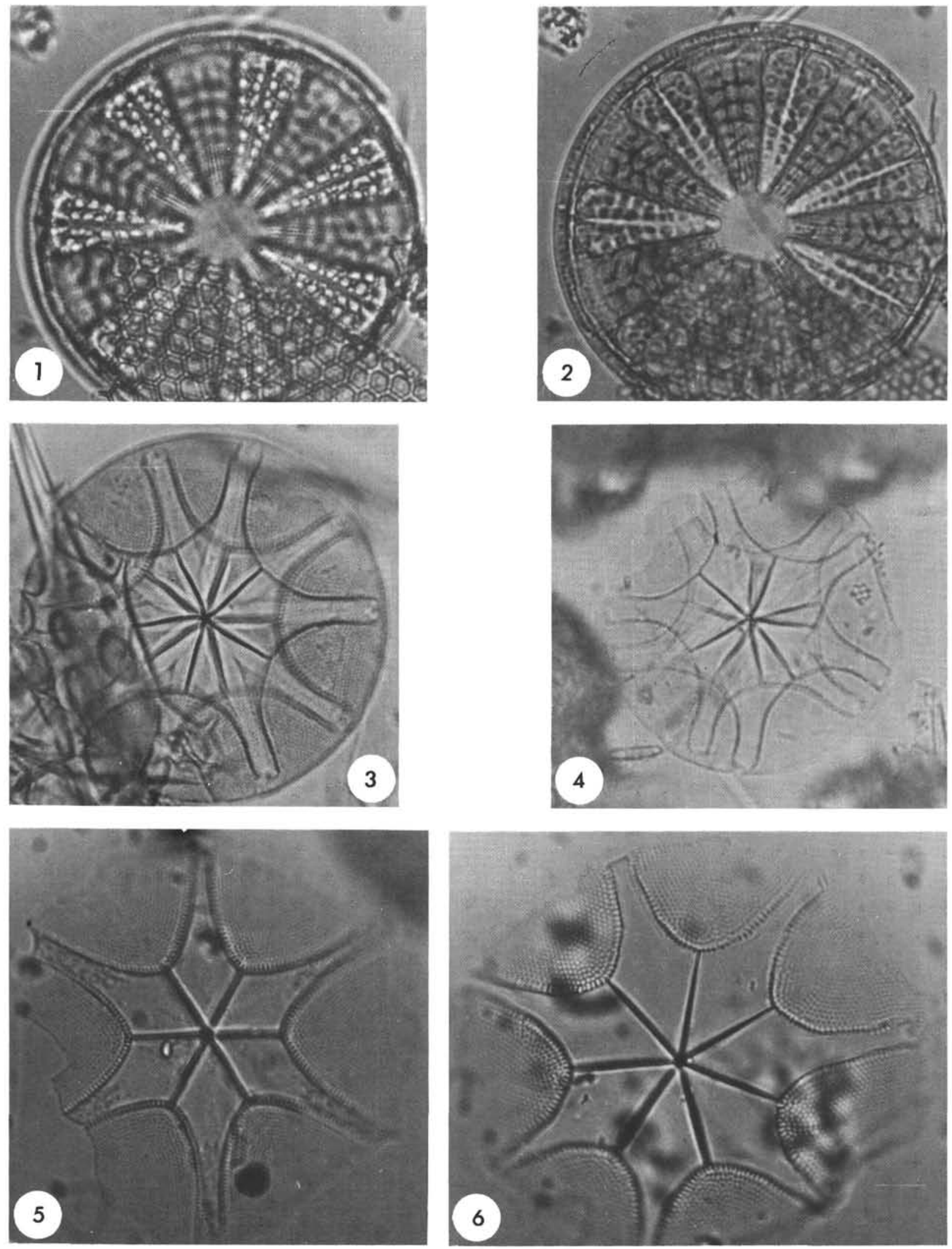
PLATE 10

Diatom Photomicrographs: $600 \times$

Except Figure 5, Which Is 300

Figure $1 \quad$ Asterolampra sp. [8-section] DSDP 157-26(CC).

Figures 2-3 Asteromphalus arachne (Brébisson)

2. DSDP 157-37(CC).

3. DSDP $157-17(\mathrm{CC})$.

Figures 4-5 Asteromphalus brookei (Ehrenberg)

4. DSDP 158-13(CC).

5. DSDP 157-2(CC).

Figures 6-9 Asteromphalus decorus (Greville)

6. DSDP 158-25(CC).

7. DSDP 158-30(CC).

8. DSDP 158-22(CC).

9. DSDP 158-20(CC). 
PLATE 10
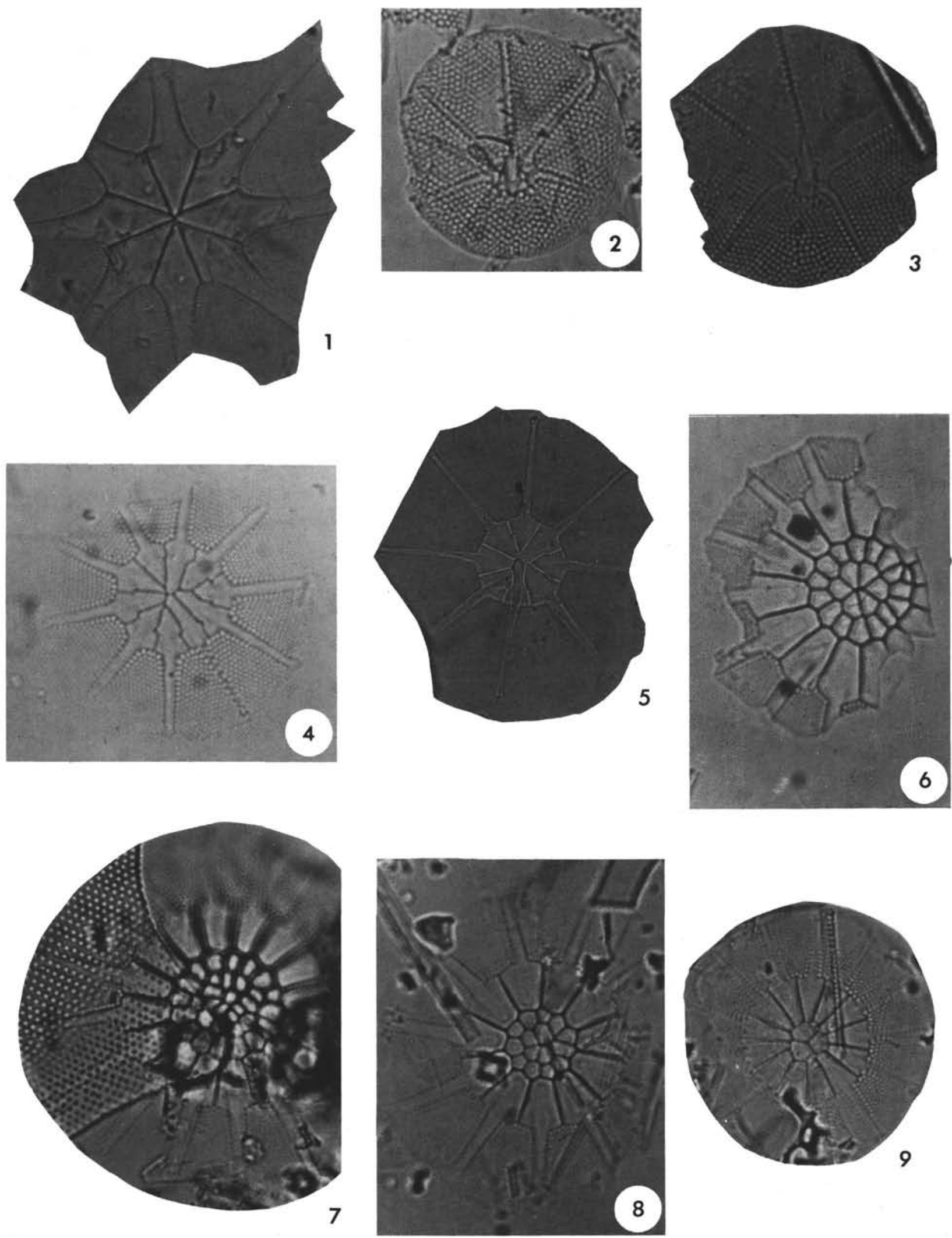

8 


\section{PLATE 11}

Diatom Photomicrographs: $600 \times$

Figures 1-2 Asteromphalus heptactis (Brébisson)

1. DSDP 157A-2A(CC).

2. DSDP $157-18(C C)$.

Figures 3-4 Asteromphalus imbricatus Wallich

3. DSDP 158-14(CC).

4. DSDP 157-3(CC).

Figures 5-6 Asteromphalus moronensis (Greville)

5. DSDP 158-20(CC).

6. DSDP 158-20(CC).

Figure 7

Asteromphalus sp., ?transitional to Asterolampra DSDP 158-32(CC). 
PLATE 11
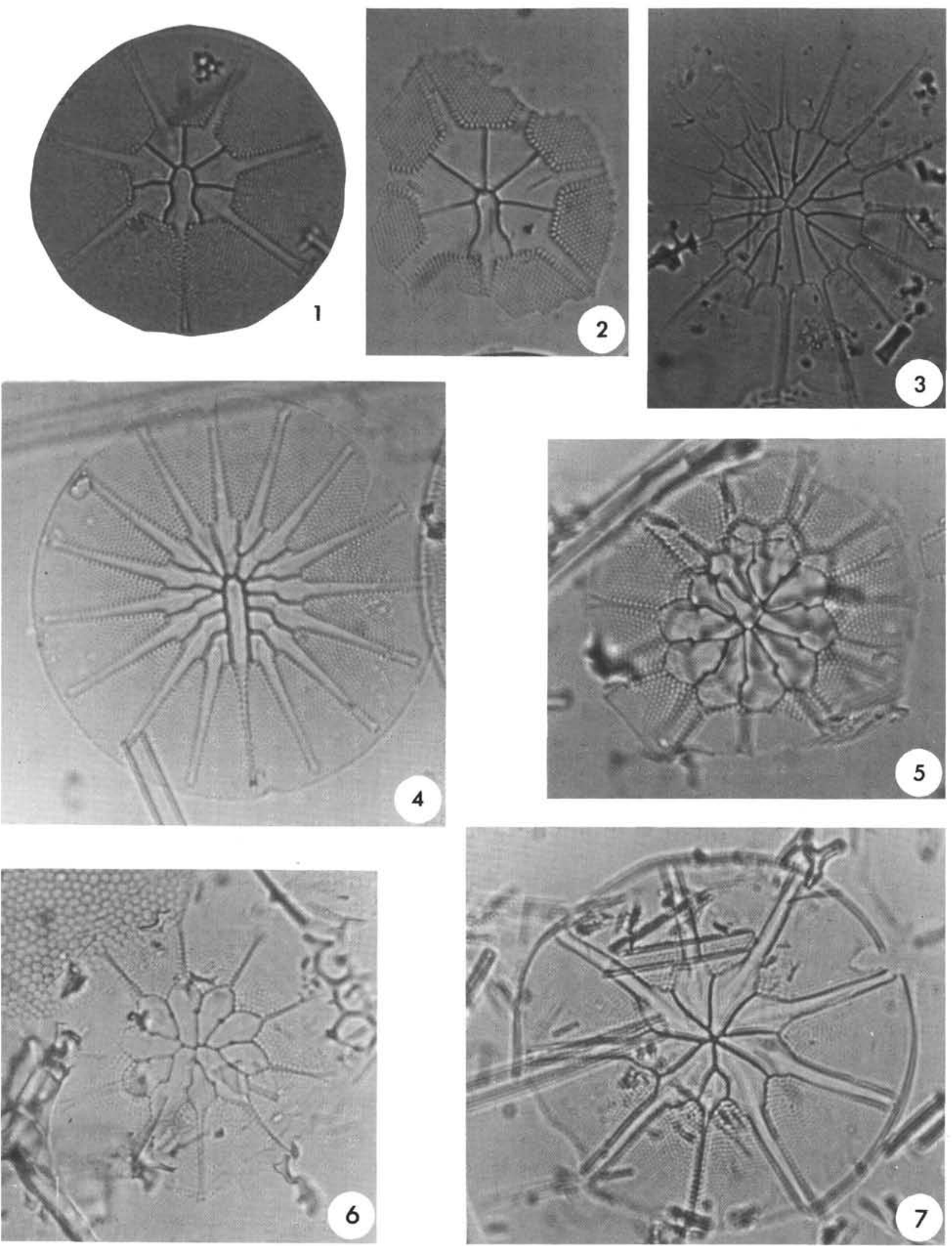
PLATE 12

Diatom Photomicrographs

Figure 1

Asteromphalus wyvillii Castracane DSDP 157-2A(CC), $600 \times$.

Figure 2 Coscinodiscus africanus Janisch DSDP $157-30(C C), 600 \times$.

Figure 3 Coscinodiscus asteromphalus Ehrenberg DSDP 157-11(CC), $300 \times$.

Figures 4-5 Coscinodiscus curvatulus Grunow

4. DSDP $157-3(C C), 600 \times$.

5. DSDP $157-24(C C), 600 \times$.

Figures 6-8 Coscinodiscus elongatus Grunow

6. DSDP 158-6(CC), $600 \times$.

7. DSDP $157-18(C C), 300 \times$

8. DSDP $158-12(C C), 300 \times$. 
PLATE 12
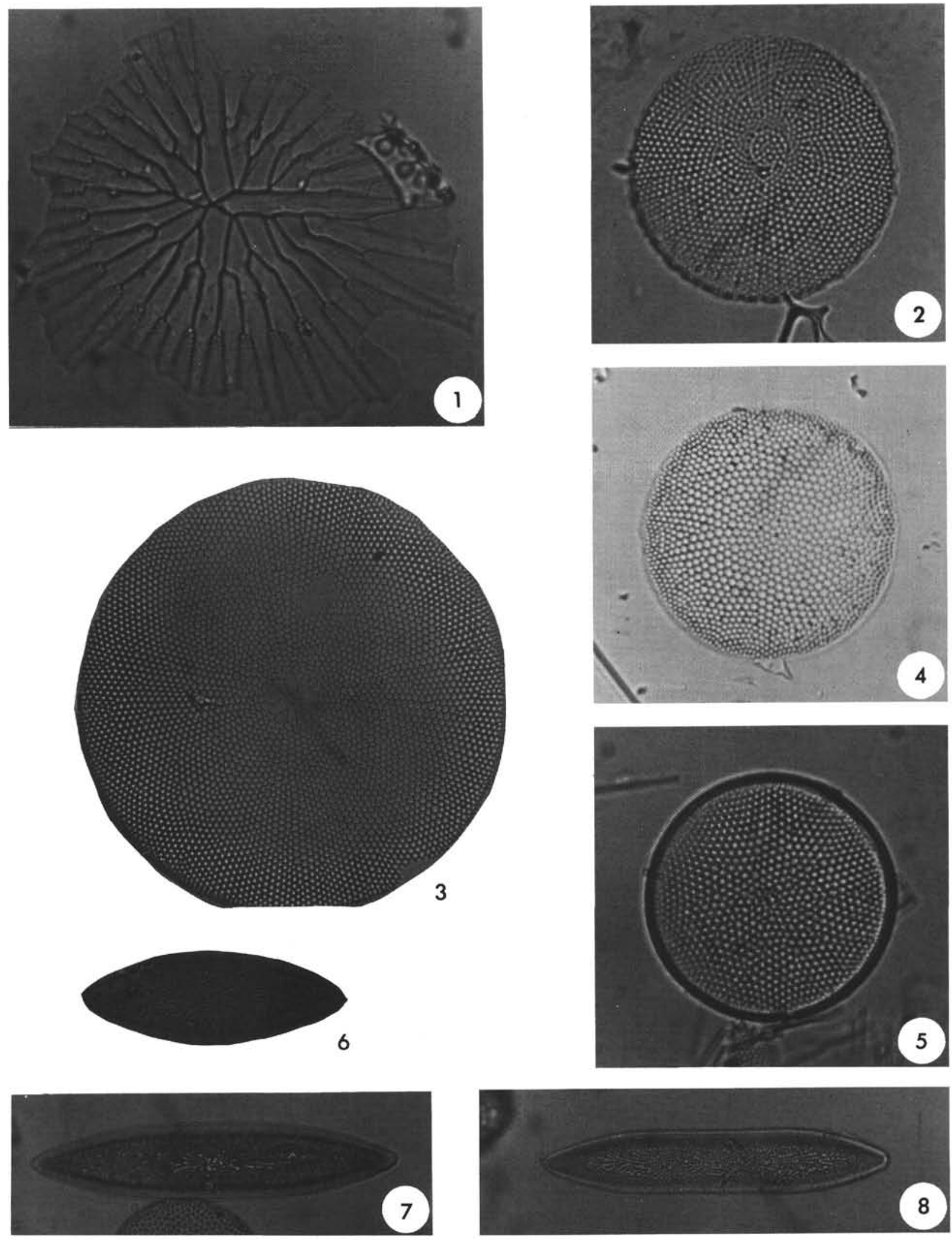


\section{PLATE 13}

Diatom Photomicrographs: $600 \times$,

Except Figures 5 and 9, Which Are $300 \times$, and Figure 1, Which Is $120 \times$

Figure 1 Coscinodiscus gigas diorma (Schmidt) s. s. DSDP 158-31(CC), $120 \times$.

Figures 2-4 Coscinodiscus lineatus Ehrenberg

2. DSDP 157-27(CC).

3. DSDP $158-13(\mathrm{CC})$.

4. DSDP 157-8(CC).

Figure $5 \quad$ Coscinodiscus lineatus Ehrenberg [at left] Coscinodiscus excentricus Ehrenberg [at right] DSDP 157-18(CC), $300 \times$.

Figures 6-7 Coscinodiscus lewisianus Greville

6. EM 7-2, $25-27 \mathrm{~cm}$.

7. DSDP $158-22(\mathrm{CC})$.

Figure 8

\section{Coscinodiscus marginatus Ehrenberg} DSDP 158-32(CC).

Figure 9 Coscinodiscus nodulifer Schmidt DSDP 157A-2A(CC), $300 \times$.

Figure 10 Coscinodiscus paleaceus Grunow DSDP 158-30(CC).

Figure 11 Coscinodiscus plicatus Grunow DSDP 158-20(CC). 

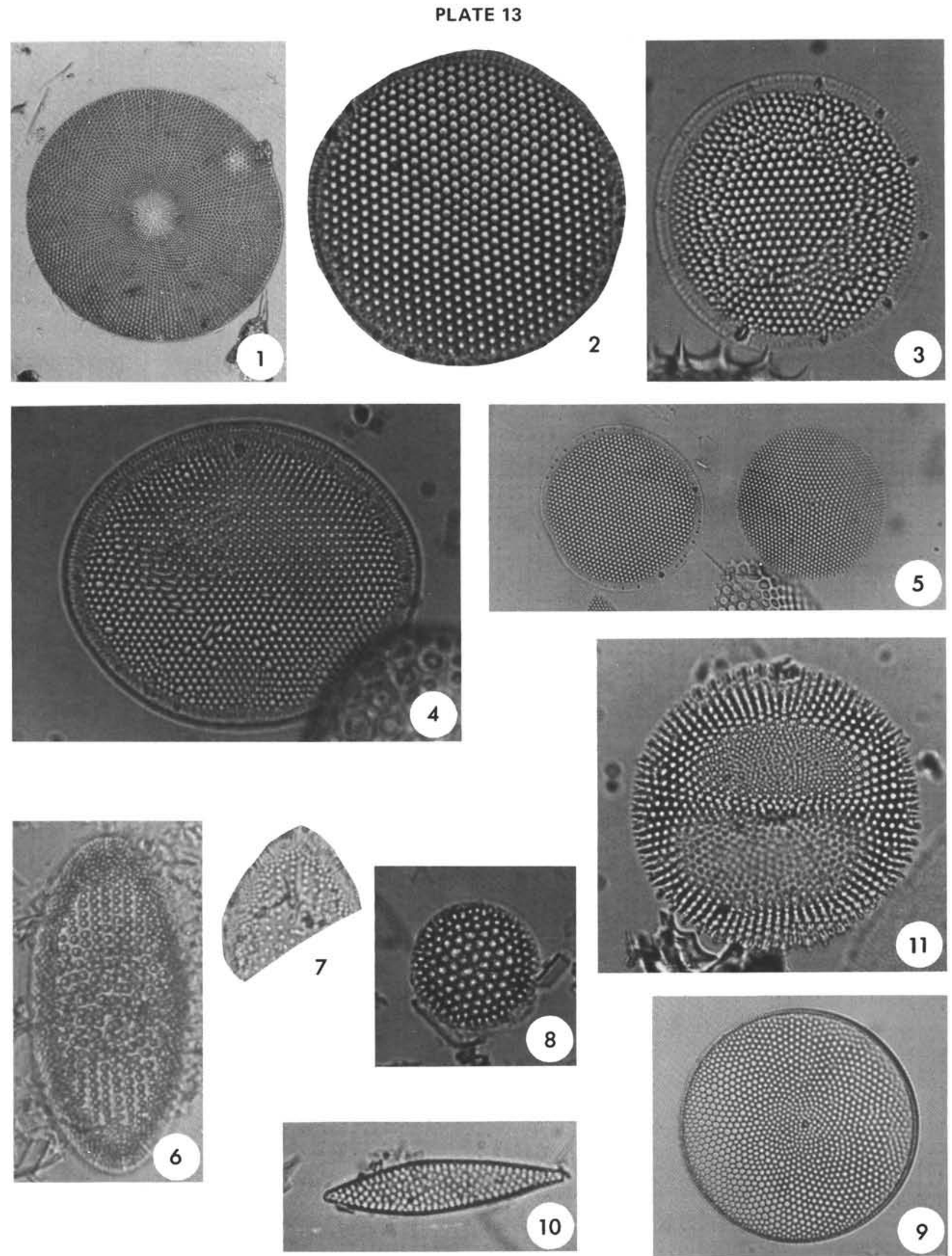
PLATE 14

Diatom Photomicrographs

Figure 1 Coscinodiscus vetutissimus Pantocsek DSDP 158-30(CC), $300 \times$.

Figure 2 Coscinodiscus sp. [irregular margin] DSDP $157-37(C C), 300 \times$.

Figure $3 \quad$ Craspedodiscus coscinodiscus Ehrenberg DSDP $158-32(\mathrm{CC}), 600 \times$.

Figures 4-5 Denticula hustedtii Simonsen and Kanaya

4. DSDP 158-26(CC), $1200 \times$.

5. Same, dark field phase contrast.

Figure 6 Denticula lauta Bailey DSDP $158-26(C C), 1200 \mathrm{~N}$, dark field phase contrast.

Figure 7

Ethmodiscus rex Rattray DSDP $158-10(C C), 600 \times$, fragment.

Figures 8-10 Fragilariopsis pliocena Brun

8. DSDP $157-28(C C), 600 \times$.

9. DSDP $157-24(C C), 600 \times$.

10. DSDP $157-7(\mathrm{CC}), 600 \times$.

Figures 11-12 Hemidiscus cuneiformis Wallich

11. DSDP $158-21(\mathrm{CC}), 300 \times$.

12. DSDP $158-16(C C), 600 \times$. 

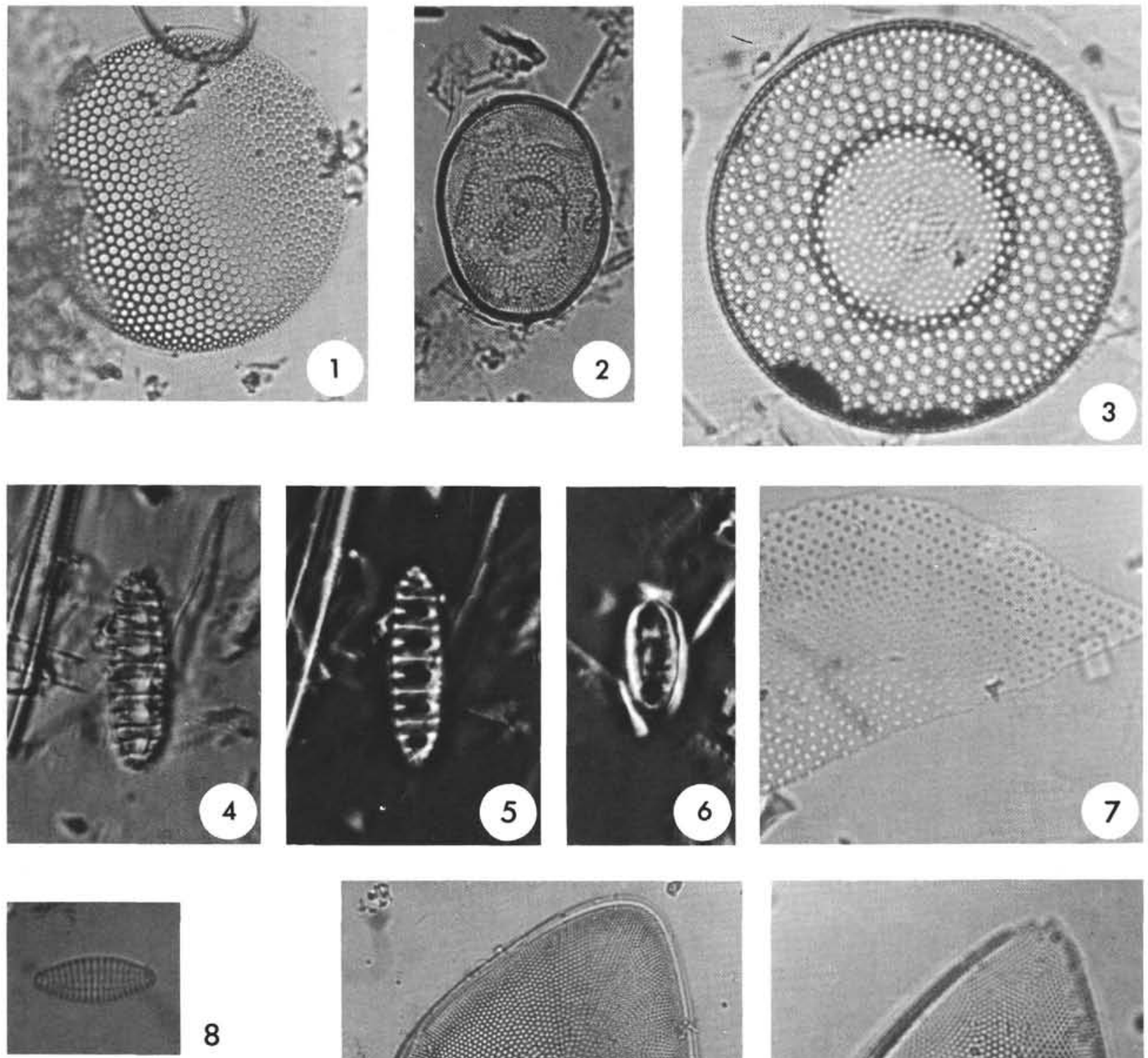

8
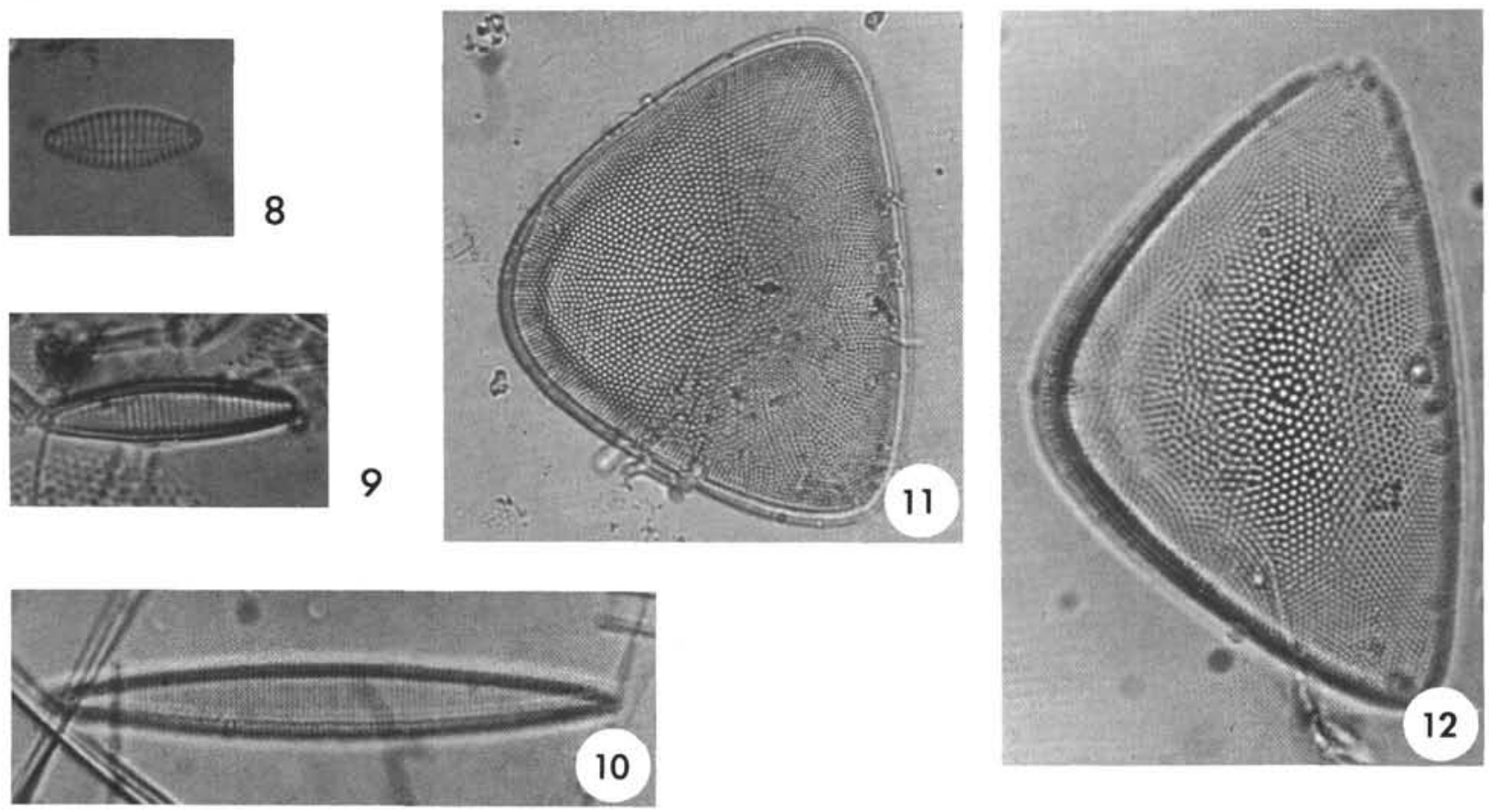


\section{PLATE 15}

Diatom Photomicrographs

Figure 1

Figure 2

Figure 3

Figure 4

Figure 5

Figures 6-8
Liostephania sp. DSDP $158-25(\mathrm{CC}), 600 \times$.

Nitzschia marina Grunow DSDP 158-12(CC), $300 \times$.

Pleurosigma sp. DSDP 157-19(CC), $300 \times$.

Pseudoeunotia doliolus (Wallich) DSDP 157-26(CC), $600 \times$.

Rhizosolenia bergonii Peragallo DSDP $157-1(\mathrm{CC}), 600 \times$.

Chaetoceros sp.

6. DSDP $158-9(\mathrm{CC}), 300 \times$.

7. DSDP $157-11(C C), 300 \times$.

8. DSDP $158-11(C C), 600 \times$.

Roperia tesselata (Roper)

9. DSDP $157 \mathrm{~A}-1 \mathrm{~A}(\mathrm{CC}), 300 \times$

10. DSDP $157 \mathrm{~A}-2 \mathrm{~A}(\mathrm{CC}), 300 \times$, high focus.

11. Same, low focus. 
PLATE 15
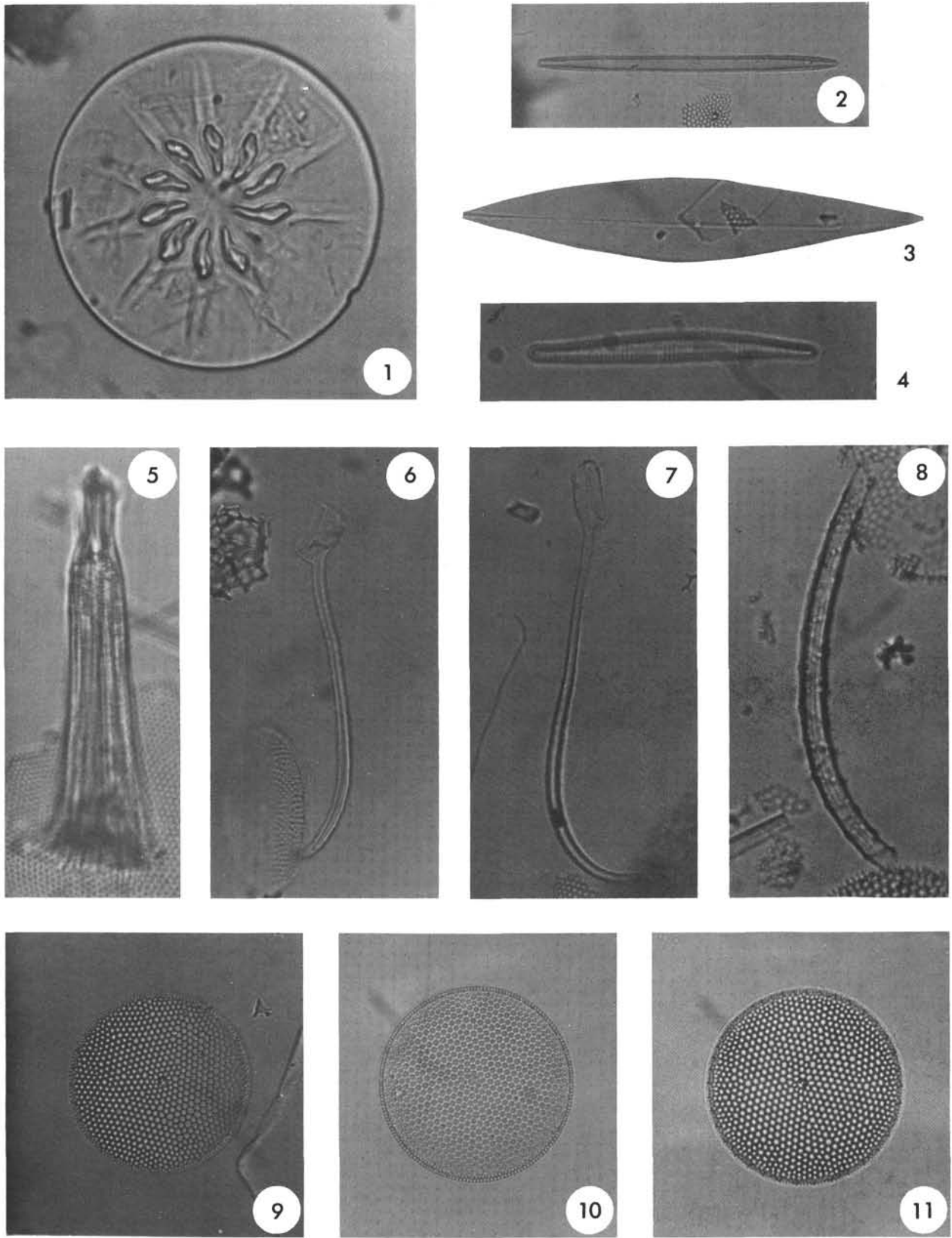
PLATE 16

Diatom Photomicrographs

Figures 1-2 Stictodiscus $\mathrm{sp}$. cf. S. californicus Greville

1. DSDP $158-25(\mathrm{CC}), 600 \times$.

2. DSDP $157-23(C C), 300 \times$.

Figures 3-6 Stictodiscus trigonus Castracane

3. DSDP 157A-1A-2, 8-10, cm, $600 \times$.

4. DSDP $157-2(C C), 300 \times$.

5. DSDP $157-1(\mathrm{CC}) 600 \times$.

6. DSDP 158-33(CC), $600 \times$.

Figures 7-8 Thalassionema nitzschioides (Grunow) s. $l$.

7. DSDP $157-37(C C), 600 \times$.

8. DSDP $157-37(C C), 600 \times$.

Figure 9 Thalassiothrix sp.

DSDP $158-27(C C), 1200 \times$, fragment, dark field phase contrast.

Figures 10-11 Triceratium cinnamomeum Greville

10. DSDP $157-32(\mathrm{CC}), 600 \times$.

11. DSDP $158-30(C C), 600 \times$.

Figure 12 ?Triceratium thumii Schmidt

12. DSDP $158-30(C C), 600 \times$. 
PLATE 16
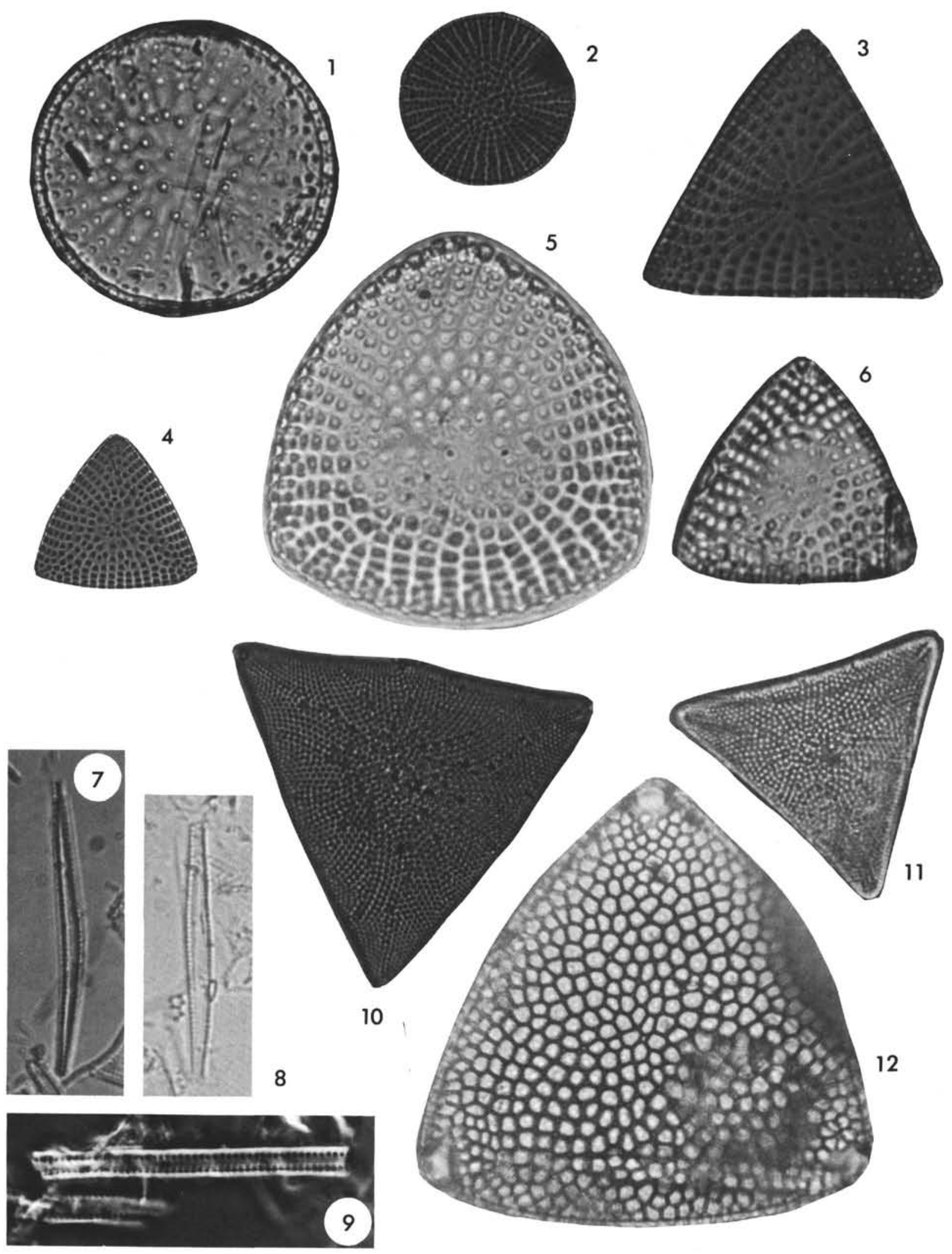


\section{PLATE 17}

Diatom Photomicrographs: $600 \times$, Except Figures 1 and 3, Which Are $300 \times$

Figure 1

Auliscus sp. DSDP $157-18(C C), 300 \times$.

Figure 2

Bacteriastrum sp. DSDP 157-14(CC).

Figure 3

\section{Biddulphia sp.} DSDP 157-23(CC), $300 \times$.

Figure 4

Diploneis sp. DSDP 157-15(CC).

Figure 5

Grammatophora sp. DSDP 158-34(CC).

Figure 6

Navicula sp. DSDP 157A-1A-4(8-10 cm).

Figure 7

Surirella sp. DSDP 157-1(CC).

Figure 8

Thalassiosira decipiens (Grunow) DSDP 157-25(CC).

Figure 9

\section{Triceratium sp.} DSDP $157-8(\mathrm{CC})$. 
PLATE 17
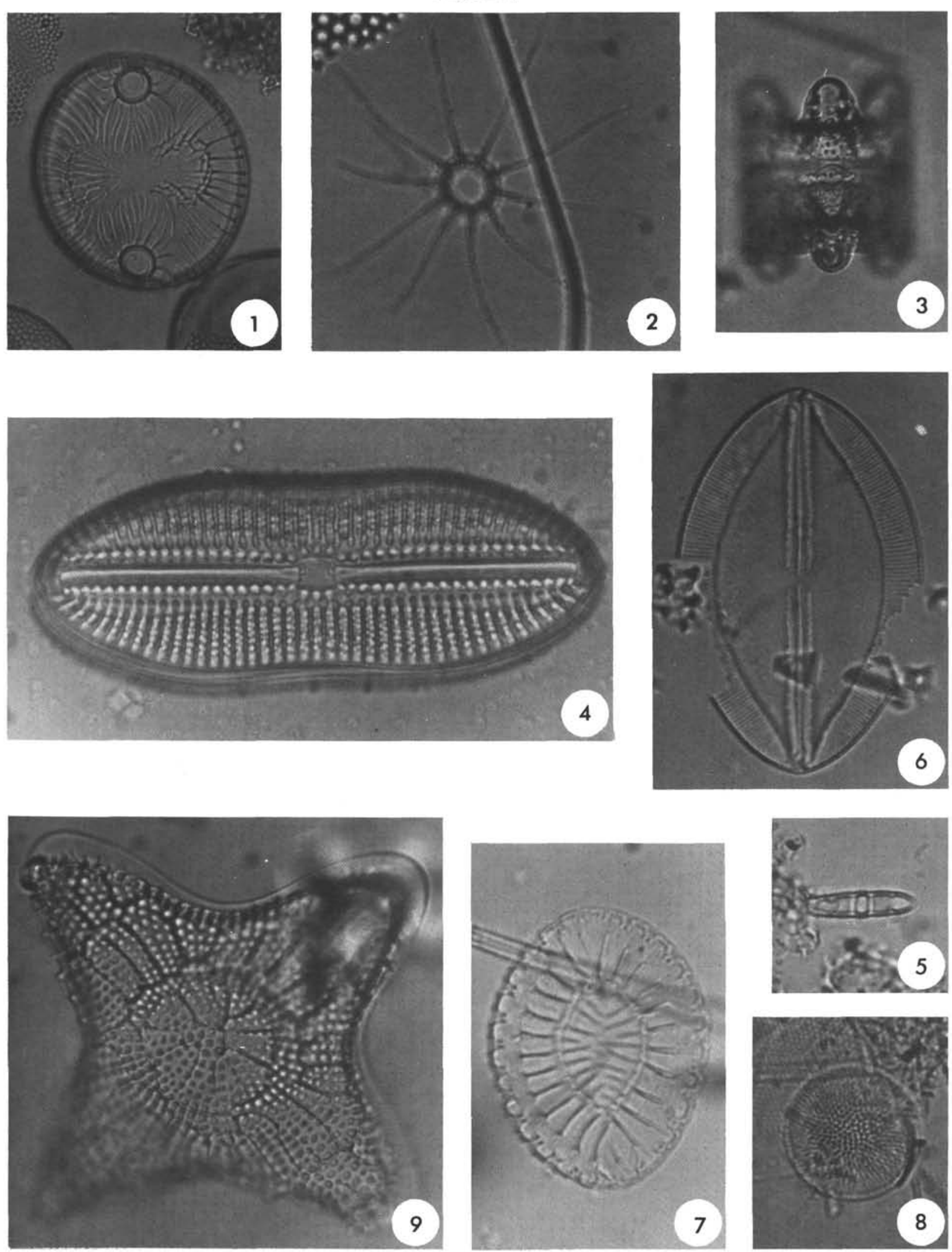